\title{
Article
}

\section{A Consumer-Welfare Approach to the Mandatory Unbundling of Telecommunications Networks}

\author{
Jerry A. Hausman ${ }^{\dagger}$ and J. Gregory Sidak ${ }^{\dagger+}$
}

\section{CONTENTS}

I. INTRODUCTION

II. A HISTORY OF NETWORK UNBUNDLING

A. From Divestiture to the 1996 Legislation ...............................426

B. The Telecommunications Act of 1996 ....................................429

1. Bell Company Provision of Long-Distance Services ......430

2. Competition in Local Telephony.

C. The FCC's Interpretation of the Act's "Necessary" and

"Impair" Requirements

III. THE SUPREME COURT ON "NECESSARY" AND "IMPAIR"

A. Justice Scalia's Opinion for the Court

$\dagger$ MacDonald Professor of Economics, Massachusetts Insutute of Technology.

$\uparrow \div$ F.K. Weyerhaeuser Fellow in Law and Economics, American Enterprise Institute for Public Policy Research. The authors thank Hal J. Singer for invaluable comments. An earlier version of this Article was submitted as an affidavit to the Federal Communications Commission on behalf of the United States Telephone Association in May 1999.

As this Article was going to press, the FCC released its Third Report and Order. promulgating interpretations of the "necessary" and "impair" standards of $\$ 251$ (d)(2) in response to the Supreme Court's Iowa Utilities Board decision. See Third Report and Order and Fourth Further Notice of Proposed Rulemaking. Implementation of the Local Competition Provisions of the Telecommunications Act of 1996, FCC 99-238 (released Nov. 5, 1999), arailable in 1999 WVL 1008985. - Ed. 
B. Justice Breyer's Concurring Opinion

1. The Purpose of the Telecommunications Act

2. The FCC's Pricing Rules for Unbundled Network Elements

3. The "Necessary" and "Impair" Requirements

C. Justice Souter's Dissent

D. On Remand.

IV. Why Limiting PRINCIPLES ARE NEEDED

A. Consumer Welfare: Competition Rather than Competitor Protection.

1. The Goal of the Telecommunications Act

2. Iowa Utilities Board.

3. Consumer Welfare in Antitrust Jurisprudence.

B. The FCC's Failure To Advance Consumer Welfare

C. The Ability of ILECs To Negotiate Privately with CLECs

D. Mandatory Unbundling Distorts Incentives

1. Incentives of Incumbents 458

2. Incentives of Entrants

E. The Effects of Removing TELRIC Pricing

F. The Importance of Sunk Costs 462

G. The Commission's Artificial Justifications for Mandatory

Unbundling

1. Conferral of a Valuable Option on the CLEC

2. Distorting the Price Elasticity of Derived Demand .......464

3. The Commission's Endogenous Determination of the Substitutability of Wireline Access for Wireline Loops.

V. LIMITING PRINCIPLES DERIVED FROM MODERN ANTITRUST

JURISPRUDENCE

A. The Logic and Limits of the Essential Facilities Doctrine ......467

B. Deriving the "Necessary" and "Impair" Standards from the Essential Facilities Doctrine.

1. Temporal and Geographic Specificity .

2. Incorporating Derived Demand.

3. The Relevant Product Market and Critical Share

C. A Proposed Test for the "Impairment" Standard

D. A Proposed Test for the "Necessary" Standard

VI. APPLYING THE PROPOSED TEST FOR “IMPAIRMENT" TO SPECIFIC NETWORK ELEMENTS 
A. The Influence of Supply-Side Effects on the Unbundling of Specific Network Elements.

1. The Supply of Existing Network Elements Listed in the Local Competition First Report and Order

a. Local Switching

b. Unbundled Loops

c. Other Network Elements

2. New Technologies for Which the FCC Potentially Could Mandate Network Unbundling

3. Combinations of Elements

B. The Influence of Demand-Substitution Effects on the Unbundling of All Network Elements.

C. The Relationship Between an "Efficient-Competitor" Standard and the Consumer-Welfare Standard.

VII. PROCEDURES FOR EFFICIENTLY ADMINISTERING THE IMPAIRMENT TEST.

A. Evidentiary Burdens and Sunset Mechanisms

B. The Proper Role of State Commissions in Administering the Proposed Test 


\section{INTRODUCTION}

In January 1999, the Supreme Court decided AT\&T Corp. v. Iowa Utilities Board, ${ }^{1}$ the Court's first interpretation of the provisions of the Telecommunications Act of 1996 by which Congress intended, among other goals, to open markets for local telephony to competition. The precise issues before the Court in Iowa Utilities Board were arcane, but the case principally involved two questions: First, does the Federal Communications Commission (FCC) have jurisdiction to set prices for unbundled network elements-the building blocks of the local telecommunications network-or does such power reside with the states? Second, which such elements do incumbent telephone companies have the legal duty to unbundle - that is, to offer for sale on a disaggregated basis-at cost-based rates to competing local-exchange carriers (CLECs), so that the CLECs can produce their own services? In addressing the second question, both Justice Scalia's majority opinion and Justice Breyer's separate opinion in Iowa Utilities Board alluded to the essential facilities and market-power analyses familiar to antitrust jurisprudence, and invited the FCC, on remand, to consider that body of law as a possible approach in determining when a network element would satisfy the "necessary" and "impair" standards of $\S 251$ (d)(2) of the Telecommunications Act, which govern when a network element is subject to mandatory unbundling. ${ }^{2}$

Responding to that invitation by the Justices, this Article explains how economic analysis and antitrust jurisprudence would inform the Commission's statutory interpretation of $\S 251(\mathrm{~d})(2)$. We propose a consumer-welfare model for the mandatory unbundling of telecommunications networks. In this Article, we reconcile the "necessary" and "impair" standards of $\$ 251$ (d)(2) of the Telecommunications Act with the economic principles that provide the basis for antitrust and competition analysis. Our approach is responsive both to the Court's decision in lowa Utilities Board and to the FCC's subsequent Second Further Notice of Proposed Rulemaking. ${ }^{3}$

1. 119 S. Ct. 721 (1999).

2. Section 251 (d)(2) provides in full:

In determining what network elements should be made available for purposes of subsection (c)(3) of this section, the Commission shall consider, at a minimum. whether-

(A) access to such network elements as are proprietary in nature is necessary; and

(B) the failure to provide access to such network elements would impair the ability of the telecommunications carrier seeking access to provide the services that it seeks to offer.

47 U.S.C.A. $§ 251$ (d)(2) (West Supp. 1999).

3. Second Further Notice of Proposed Rulemaking, Implementation of the Local Competition Provisions in the Telecommunications Act of 1996, FCC 99-70, 121 (released Apr. 16, 1999). available in 1999 WL 221834 ("We nevertheless seek comment on the significance of the essential facilities standard under section 251 (d)(2)."); id. I 22 ("We ask parties to describe lihe 
To advance the ultimate goal of encouraging the development of a competitive market for local telephony, the Telecommunications Act of 1996 sets forth rules governing the unbundling of local telecommunications networks. ${ }^{4}$ The essence of the lowa Utilities Board ruling is that the FCC must devise a limiting principle for implementing these rules. In the 1996 Local Competition First Report and Order, ${ }^{5}$ its first stab at implementing the unbundling rules, the FCC had no serious limiting principle. The FCC defined a "necessary" unbundling under the statute to be any technically feasible one, and the First Report and Order gave the definition of "impairment" a similarly limitless scope. The Commission found that an incumbent local exchange carrier (ILEC) had to unbundle any nonproprietary network element if, in the absence of such unbundling, a telecommunications carrier seeking to offer a service would suffer even the slightest "impairment" of its ability to do so. The Court, in Iowa Utilities Board, rejected this approach and strongly suggested that the economic analysis underlying antitust law provided the Commission with a useful model for interpreting $\$ 251$ (d)(2). ${ }^{6}$

That is not to say that the Commission's interpretation of $\$ 251$ (d)(2) must incorporate by reference all of antitrust law. Rather, addressing the issue within the legal context of an agency interpretation of a newly enacted statute, the Court identified two discrete points along a continuum. The first point, embodied by the FCC's Local Competition First Report and Order, authorized any technically feasible unbundling. The second point incorporated the lessons of the essential facilities doctrine. Only a portion of the continuum constitutes a zone of reasonable statutory interpretations for purposes of the Chevron doctrine. ${ }^{7}$ The First Report and Order was, in the Court's determination, plainly outside the zone of reasonable interpretations of "necessary" and "impair." The Court's opinion implies that the essential facilities doctrine and related economic analysis of demand and supply

essential facilities doctrine] and how it should be applied, if it all, to the determination of which network elements incumbent LECs must provide on an unbundled basis.").

4. See 47 U.S.C.A. $\S \S 251-252$. For detailed discussions of this open-access regulation, see ALFRED E. KAHN, LETTING GO: DEREGULATING THE PROCESS OF DEREGULATION 47-53, $90-96$ (1998); J. Gregory SidAK \& Daniel F. SPUlber, Deregulatory Takings and the REgULATORY CONTRACT (1997); Robert G. Harris \& C. Jeffrey Kraft. Meddling Through: Regulating Local Telephone Competition in the United States, J. ECON. PERSP.. Fall 1997, at 93, 102-11; and J. Gregory Sidak \& Daniel F. Spulber. The Tragedy of the Telecommons: Government Pricing of Unbundled Network Elements Under the Telecomununications Act of 1996. 97 CoLUM. L. REv. 1081 (1997). For an analysis of unbundling policy pursued through antitnust law rather than through regulation, see Abbott B. Lipsky. Jr. \& J. Gregory Sidak, Essential Facilities, 51 STAN. L. REV. 1187 (1999).

5. First Report and Order, Implementation of the Local Competition Provisions in the Telecommunications Act of 1996, 11 F.C.C.R. 15,499 (1996). This order was vacated in part by the Eighth Circuit; the Supreme Court then modified the Eighth Circuit's decision in lowa Utilities Board. See Iowa Utils. Bd. v. FCC. 120 F.3d 753 (8th Cir. 1997), rev'd in part and aff d in part sub nom. AT\&T Corp. v. Iowa Utils. Bd., 119 S. Ct. 721 (1999).

6. See Iowa Utils. Bd., 119 S. Ct. at 734-36.

7. See Chevron U.S.A. v. Natural Resources Defense Council. 467 U.S. 837, 842-45 (1984). 
substitution would produce definitions of "necessary" and "impair" that would safely fall within the zone of reasonable interpretations of $\$ 251$ (d)(2). It does not follow, of course, that the Commission should pick any point that lies in the zone of reasonableness along the continuum of possible statutory interpretations. Rather, the Commission should adopt an interpretation that represents its best efforts to identify the optimal point along the continuum, where "optimality" is realized through consumer-welfare maximization.

The FCC intimated in its Second Further Notice that it intends to adopt an approach remarkably similar to that in the Local Competition First Report and Order. We urge the Commission to accept the invitation of Justices Scalia and Breyer to bring its interpretation of $\S 251$ (d)(2) in line with established antitrust principles. Indeed, the leading antitrust treatise recently echoed such advice. $^{8}$ The purpose of this Article is to explain how the Commission can successfully put that advice into practice.

In Part II of this Article, we review the pertinent legal and economic developments in the telecommunications industry that preceded Iowa Utilities Board, and we provide a context for subsequent examination of the meaning of the "necessary" and "impair" standards of $\S 251$ (d)(2). In particular, we review the AT\&T divestiture of 1984, the Telecommunications Act of 1996. and the relationship between mandatory unbundling of incumbent localexchange networks and the prohibition on Bell company provision of long-distance services.

In Part III, we examine the reasoning used by Justices Scalia and Breyer to interpret the "necessary" and "impair" standards of $\$ 251(\mathrm{~d})(2)$. Our analysis begins with the proposition that Congress did not intend to create a conflict in objectives between the Telecommunications Act and the existing body of antitrust jurisprudence. Antitrust law primarily seeks to maximize the well-being of consumers. ${ }^{9}$ Similarly, Congress stated that the purpose of the Telecommunications Act of 1996 was to "promote competition and reduce regulation in order to secure lower prices and higher quality services for American telecommunications consumers and encourage the rapid

8. Endorsing Justice Breyer's analogy to the essential facilities doctrine as "inescapable" logic, Professor Hovenkamp writes:

The principal purpose of the 1996 Telecommunications Act is to deregulate. and deregulation can be accomplished only by minimizing the occasions for regulatory supervision. Competition requires that inputs economically capable of being supplied competitively - that is, by numerous independent sources-be supplied in that manner. Forced sharing of such inputs acts as a disincentive to producing them competitively in the first place and exacerbates and prolongs agency supervision.

PHILLIP E. AREEDA \& HERBERT HOVENKAMP, ANTITRUST LAW: AN ANALYSIS OF ANTITRUIST PRINCIPLES AND THEIR APPLICATION $177^{\circ} \mathrm{c}$, at 247 (Supp. 1999).

9. This principle is well established in antitrust law. See, e.g., NCAA v. Board of Regents. 468 U.S. 85, 107 (1984); Reiter v. Sonotone Corp., 442 U.S. 330, 343 (1979) (citing RoBERT H. BORK, THE ANTITRUST PARADOX 66 (1978)). For special application of the consumer-welfare criterion to industries undergoing deregulation, see Stephen G. Breyer, Antitrust, Deregulation. and the Newly Liberated Marketplace, 75 CAL. L. REV. 1005 (1987). 
deployment of new telecommunications technologies." 10 Both antitrust law and the Telecommunications Act seek to promote the competitive process and to protect legitimate returns to private investment, not the returns to particular competitors or particular market structures. The opinions of Justices Scalia and Breyer recognized these principles. Both Justices indicated that, although the Commission has the discretion under Chevron to promulgate rules predicated on reasonable interpretations of the Telecommunications Act, it would not be reasonable in light of Iowa Utilities Board for the agency to interpret $\S 251(\mathrm{~d})(2)$ in a manner that diverged from the essential facilities and market power principles in antitrust law. In dismissing such economic analysis as irrelevant to the interpretation of the Telecommunications Act, the FCC failed to recognize consumer-welfare maximization as the proper objective of the 1996 legislation.

In Part IV, we set forth a number of guiding principles that together demonstrate the need for substantive limiting principles for the mandatory unbundling of network elements. The first principle is that unbundling rules should emphasize consumer welfare and competition rather than competitor welfare. A competitor-welfare standard would in effect impose no limit on mandatory unbundling. Second, the issue is not whether the ILECs will unbundle their network elements for use by CLECs, but whether the government will compel the ILECs to do so at regulated prices set on the basis of total element long-run incremental cost (TELRIC), which would force ILECs to subsidize CLECs. The third principle is that the social costs of a particular unbundling regime may outweigh the gains. Fourth, the "necessary" and "impair" standards should not rely on an economic misconception of sunk costs in local telecommunications. Finally, the apparent justification for mandatory unbundling can be endogenously distorted by the FCC's own policies, particularly the inefficient and noncompensatory pricing of unbundled network elements (UNEs). ${ }^{\text {"I }}$

In Part $\mathrm{V}$, we offer, as appropriate limiting principles for network unbundling, those inherent in the essential facilities doctrine and in the competitive analysis of demand and supply substitution that informs

10. Telecommunications Act of 1996. Pub. L. No. 104-104, pmbl.. 110 Stat. 56. 56.

11. Two years before passage of the Telecommunications Act of 1996, Professor William J. Baumol and one of the present authors wrote:

[R] policies that affect the firm's actual or potential competitors. Clearly, severe constraint of firms' entry and pricing will somewhat immunize each enterprise from the competitive pressures of others. That immunity from competition will reduce the elasticity of each supplier's demand-that is, it will reduce the loss of business that results from a rise in its prices. The firm's price elasticity of demand thus must be said to be endogenously determined by the regulatory process itself ... .

It appears especially clear in telecommunications that a firm's price elasticity of demand is endogenously determined by its regulatory environment.

William J. BAUMOL \& J. GREGORY SidAK. TOWARD COMPETITION IN LOCAL TElePHONY 4041 (1994). 
traditional antitrust analysis of market power. We use antitrust jurisprudence to suggest economic definitions for " necessary" and "impair."

One immediate lesson is that sound economic analysis counsels the FCC to interpret $\S 251(\mathrm{~d})(2)$ to impose geographic and temporal limitations on mandatory unbundling. That conclusion flows directly from an established body of antitrust jurisprudence on market definition and market power. Before the Commission will be able to conclude with any degree of confidence that its order of mandatory unbundling would serve the public interest and enhance consumer welfare, ${ }^{12}$ it-or, preferably, the state public utilities commissions-would be well advised to make market-power determinations in each relevant geographic market for each network element for which the agency proposes to mandate unbundling. That market-power analysis should be based on a specified time horizon, after which the requirement of unbundling for that network element should sunset unless the access-seeker successfully carries the burden of proving that consumer welfare would suffer without the Commission's continuation of such mandatory unbundling.

Second, the definitions of "necessity" and "impairment" should be refined using the principles of demand and supply substitution. The "necessity" of unbundling a proprietary network element, and the extent to which competition would be "impaired" if a nonproprietary element were not unbundled, depend upon the respective price elasticities of demand and supply in both the input (unbundled network element) and output (end-user access) markets. Our recommended approach comports with the analysis of unilateral effects in the 1992 Merger Guidelines adopted by the Federal Trade Commission and the Antitrust Division of the U.S. Department of Justice. ${ }^{13}$ Antitrust jurisprudence has long incorporated such techniques for measuring market power, ${ }^{14}$ including the rules of derived demand first enunciated by one of the pioneers of modern microeconomic theory, Alfred Marshall, ${ }^{15}$ and

12. Our previous writings have emphasized the equivalence between the public-interest standard and a consumer-welfare standard. See id:; JERRY HAUSMAN, TAXATION BY TElecommunications Regulation: THE Economics of THE E-RATE 4 (1998); SidAK \& SPULBER, supra note 4, at 309-10, 340; Jerry Hausman, Valuing the Effect of Regulation on New Services in Telecommunications, 1997 BROOKINGS PAPERS ON ECON. ACTIVITY: Microeconomics 1; Jerty Hausman \& Howard A. Shelanski, Economic Welfare and Telecommunications Welfare: The E-Rate Policy for Universal Service Subsidies. 16 YALE J. ON REG. 19, 26-29 (1999); J. Gregory Sidak, Telecommunications in Jericho, 81 CAL. L. REV. 1209. 1234-38 (1993) (review essay).

13. See 1992 Horizontal Merger Guidelines, 57 Fed. Reg. 41,552, 41,560-61 (1992).

14. The seminal article is William M. Landes \& Richard A. Posner, Market Power in Antitrust Cases, 94 HARV. L. REV. 937, 944-45 (1981).

15. See 5 Alfred MARShall, PRINCIPLES of ECONOMICS 381-93 (1922). For other explications of Marshall's rules of derived demand, see P.R.G. LAYARD \& A.A. WALTERS, MICROECONOMIC THEORY 259-72 (1978). Derived demand is similar to, but distinguishable from, residual demand in the sense that the latter focuses on the demand for the end product and is calculated for any given firm by subtracting the supply of other firms from the market demand. See DEnNiS W. CaRlton \& JefFrey M. PERlofF, MOdERn INDUSTRIAL ORganization 100 (2d ed. 1994). 
subsequently exposited by the late Nobel laureate George Stigler. ${ }^{16}$ The necessity of unbundling an element, or the likelihood that failing to order mandatory unbundling of a particular element would impair competition, should be assessed in light of the existence of competition among different bundles of end services. Thus, the interpretation of "impair" with respect to loops, for example, should reflect the existence of substitution among bundles of services that use different access technologies (such as cable television's coaxial and fiber-optic infrastructure to provide local access for voice telephony, or the wireless one-rate plans that encompass "free" roaming and long-distance calling).

Part V continues by arguing that the essential facilities doctrine sets forth necessary, but not sufficient, conditions for defining "impairment" under $\S 251$ (d)(2). The complete set of necessary and sufficient conditions includes a fifth requirement, responsive to the explicit text of $\S 251$ (d)(2), that addresses whether the denial of access to that network element at TELRIC prices would impair competition at the end-user level. Once the CLEC has demonstrated that the network element meets the four requirements already contained in the essential facilities doctrine, the CLEC must then demonstrate that an ILEC could exercise market power in the provision of telecommunications services to end-users in the relevant geographic market by restricting access to the requested network element. Our five-part test is as follows:

The FCC shall mandate unbundling of a network element if, and only if:

(1) it is technically feasible for the ILEC to provide the CLEC unbundled access to the requested network element in the relevant geographic market;

(2) the ILEC has denied the CLEC use of the network element at a regulated price computed on the basis of the regulator's estimate of the ILEC's total element long-run incremental cost;

(3) it is impractical and unreasonable for the CLEC to duplicate the requested network element through any alternative source of supply;

(4) the requested network element is controlled by an ILEC that is a monopolist in the supply of a telecommunications service to end-users that employs the network element in question in the relevant geographic market; and

(5) the ILEC can exercise market power in the provision of telecommunications services to end-users in the relevant geographic market by restricting access to the requested network element. 
The fifth element is implemented by computing the "critical share" of customers that the ILEC must lose in order to deter the ILEC from exercising market power in the end-user service market. It is immediately clear that the FCC's requirement of all "technically feasible" unbundlings, articulated in the Local Competition First Report and Order, is subsumed within our five-part framework.

In Part VI, we provide some applications of our impairment test to particular network elements. Demand-side constraints on the exercise of market power, such as voice telephony over cable television networks and wireless telephony, affect all unbundled network elements equally. By contrast, we examine supply-side constraints at a UNE-specific level. We conclude that network elements with low fixed costs in geographically dense areas should not be subject to mandatory unbundling at TELRIC prices. The decision not to mandate unbundling of switches should be made on the basis of supply-side substitution possibilities alone, while the same ruling on loops would require demand-side substitution opportunities to be incorporated into the analysis. The major advantage of a consumer-welfare standard over an efficient-competitor standard is that the former focuses attention on the enduser services market and thus allows one to incorporate demand-side substitution possibilities.

Finally, in Part VII, we discuss efficient procedures for administering the impairment test. First, we explain why the CLEC should bear the burden of proving that mandatory unbundling of a particular network element is justified in a particular geographic market. Second, we contend that any mandatory unbundling order should automatically sunset within two years of the first unbundling decision. Third, we explain why state public utilities commissions should administer a market-power test that is both location-specific and factintensive.

\section{A HISTORY OF NETWORK UNBUNDLING}

\section{A. From Divestiture to the 1996 Legislation}

The modern era in U.S. telecommunications policy began in 1984 with the breakup of AT\&T, the result of an antitrust suit filed by the Department of Justice. ${ }^{17}$ AT\&T and the Department settled the suit in 1982 in what is

17. Many books have been written about the AT\&T breakup. See, e.g., ROBERT W. Crandall, After the Breakup: U.S. Telecommunications in a More Competitive ERA (1991); Paul W. Macavoy, The FaIlure of ANtITRust and Regulation To Establish

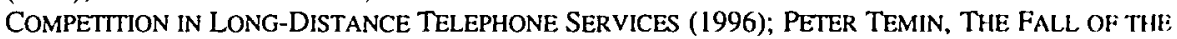
BELL SYSTEM: A STUDY IN PRICES AND POLITICS (1987). 
known as the Modification of Final Judgment (MFJ), and thus began the modern era of telecommunications regulation. ${ }^{18}$

The MFJ was the product of regulatory failure. The FCC had waged numerous battles throughout the 1970s to address the onset of competition in the U.S. telecommunications industry. Congressional attempts to revise the basic telecommunications legislation of 1934 failed. Telecommunications policy subsequently moved from the regulatory and legislative arena to the federal judiciary with the implementation of the MFJ. Federal district court Judge Harold Greene administered the MFJ until Congress passed the Telecommunications Act of 1996. The Act marked the end of the MFJ. ${ }^{19}$

Before the MFJ required divestiture, AT\&T had consisted of three main parts: (1) local companies, such as New York Telephone, which provided about eighty percent of local U.S. telephone service; (2) AT\&T Long Lines, which provided almost all domestic and international long-distance service; and (3) Western Electric, including Bell Laboratories, which provided most of the telecommunications equipment for AT\&T's local and long-distance units. After divestiture, AT\&T continued to operate the long-distance and manufacturing units, while the local companies were divested and organized into seven Regional Bell Operating Companies (RBOCs). ${ }^{20}$ The individual local Bell operating companies that constituted an RBOC came to be known as BOCs.

The rationale for the MFJ derived from the "quarantine theory." 11 Before divestiture, the local companies were thought to have market power due to a "natural monopoly," although they were regulated at both the state and federal levels to limit the exercise of any such market power. The quarantine theory determined that the BOCs should not be permitted to compete in the long-distance, manufacturing, and information services industries, in which the BOCs could distort competition, until they ceded

18. Modification of Final Judgment, in United States v. American Tel. \& Tel. Co., 552 F. Supp. 131, 226-34 (D.D.C. 1982), aff'd sub nom. Maryland v. United States, 460 U.S. 1001 (1983). The settlement was a "modification" of an earlier "final judgment" in the sense that it modified a consent decree into which AT\&T and the government had entered in 1956.

19. For an exhaustive discussion of the administration of the MFJ, sec MiChAEl K. KELlOGG ET AL., FEDERAL TELECOMMUNICATIONS LAW 199-248 (1992).

20. For instance, the New England and New York Telephone Companies became part of NYNEX, which subsequently merged with Bell Atlantic. Recent and pending mergers are likely to lead to four remaining RBOCs with GTE, the largest independent company, merging with Bell Atlantic; U S WEST, the smallest RBOC, merging with Qwest, a new long-distance company: SBC acquiring Ameritech (after having acquired Pacific Telesis); and BellSouth remaining independent but with an equity interest in Qwest. AT\&T divested its equipment munufacturing company, now called Lucent, in 1998. For an early explanation of the economic rationale behind this very successful divestiture, see Jerry A. Hausman \& Elon Kohlberg. The Future Evolution of the Central Office Switch Industry, in Future COMPETITON IN TElecomalunications 193 (Stephen P. Bradley \& Jerry A. Hausman eds., 1989).

21. See SIDAK \& SPULBER, supra note 4, at 55-99. 
their monopoly power. ${ }^{22}$ The BOCs were forbidden to carry long-distance calls from one local access and transport area, or LATA, to another. Thus, the MFJ's long-distance prohibition came to be known as a ban on "interLATA" services. The quarantine theory suggested that, in the absence of restrictions on their ability to enter new lines of business, the BOCs would cross-subsidize competitive services with their monopolized local services, and would discriminate against competing long-distance companies when providing the connection to the local network. ${ }^{23}$ The MFJ contained a waiver procedure by which the BOCs would request relief from the MFJ for specific services so long as "there [was] no substantial possibility that the [petitioning $\mathrm{BOC}$ ] could use its monopoly power to impede competition in the market it [sought] to enter." ${ }^{24}$

Events soon demonstrated that a district judge had only limited ability to oversee telecommunications policy in the United States. The technology of telecommunications was changing rapidly in the 1980s and 1990s with the introduction of digital computer-driven switches and fiber-optic transmission, but the court's evidentiary record contained information primarily from $1976 .{ }^{25}$ The use of consumer information services became widespread in France with Minitel, but the United States remained far behind. Furthermore, the MFJ's waiver process became mired in legal delay, impeding the economically efficient evolution of new technologies, such as cellular telephony. In 1993, the average waiver request had been pending for thirty-six months, despite the fact that the Department of Justice had opposed relief in only six of the 266 waiver requests filed by the RBOCs. ${ }^{26}$ By the end of 1993 , the average age of pending waiver motions

22. See Modification of Final Judgment § II.D, 552 F. Supp. at 227-28. Information services were defined to be the interaction of computer services and telecommunications.

23. To "cross-subsidize" means to set prices below incremental cost. See, e.g., BAuMOL \& SIDAK, supra note 11 , at 62 . In actuality, long-distance service had long cross-subsidized local service at the direction of regulators, and so the Department of Justice's theory was incorrect. The amount of the cross-subsidy had increased greatly as the cost of providing long-distance service fell rapidly after 1950, with regulators refusing to allow long-distance prices to fall as rapidly. See CRANDALL, supra note 17, at 24-27. MCI recognized the economic opportunity of providing long-distance service when prices far exceeded costs and regulators would not permit a reduction in prices by the regulated company. Events soon after divestiture made evident the direction of cross-subsidy from long-distance to local, as the FCC established above-cost access fees (in actuality, a tax) on long-distance to continue the cross-subsidy to local service. See TEMiN. supra note 17 , at 306-17.

24. Modification of Final Judgment § VIII.C, 552 F. Supp. at 231.

25. Ironically, 1976 was the year of the introduction of both digital electronic switches and fiber-optic transmission. MCI, the first long-distance competitor of AT\&T, had based its long-distance service on microwave transmission (hence the name from which " $\mathrm{MCl}$ " was derived: Microwave Communications, Inc.), but this technology was becoming obsolete at the time of the AT\&T trial.

26. See Paul H. Rubin \& Hashem Dezhbakhsh, Costs of Delay and Rent-Seeking Under the Modification of Final Judgment, 16 MANAGERIAL \& DECISION ECON. 385, 385-87 (1995). 
before the district court had grown to 54.7 months, ${ }^{27}$ even though the decree court had fully approved ninety-six percent of all waiver requests filed. ${ }^{28}$

The parties had agreed to a triennial review of the MFJ, and the first such review began in 1987. This review led to the removal of the MFJ's restraint on the provision of information services by the BOCs. Because of various appeals to the D.C. Circuit and subsequent remands, however, the first triennial review was not completed by either 1990 or 1993, when the next reviews had been scheduled to take place. Indeed, a second triennial review never took place.

The MFJ caused significant harm to consumers. Empirical research has demonstrated that consumer welfare suffered a loss of billions of dollars per year because of the delay in introducing new telecommunications services to consumers. ${ }^{29}$ Furthermore, the MFJ decreased long-distance competition because of its ban on BOC participation. For instance, cellular long-distance prices were at supracompetitive levels under the MFJ; they fell almost immediately by about twenty-five percent after the MFJ restrictions were removed. ${ }^{30}$ The continuing avalanche of legal filings by the BOCs, long-distance companies, and other potential competitors of the BOCs proved unmanageable for a single district court judge. ${ }^{31}$

\section{B. The Telecommunications Act of 1996}

Many people recognized that judicial supervision of the U.S. telecommunications industry was a failure. ${ }^{32}$ Congress finally overhauled the Communications Act of 1934 by passing the Telecommunications Act of 1996. The new legislation ended the MFJ and returned sole federal control of the U.S. telecommunications industry to the FCC.

The two provisions of the Act most relevant to the BOCs and other ILECs were (1) that the BOCs would be permitted to provide long-distance competition when they had satisfied the requirements of a fourteen-point, FCC-administered "checklist"; ${ }^{33}$ and (2) that they would unbundle their

27. See id. at 392.

28. See id. at $389,392$.

29. See Hausman, supra note 12, at 13-24.

30. See Jerry A. Hausman, Comperition in Long-Distance and Telecommunications Equipment Markets: Effects of the MFJ. 16 J. MANAGERIAL \& DECISION ECON. 365 (1995).

31. For a recent review praising the MFJ, see Paul L. Joskow \& Roger G. Noll, The Bell Doctrine: Application in Telecommunications, Electriciny, and Other Nenwork Industries, 51 STAN. L. REV. 1249, 1271-78 (1999). Joskow and Noll, however, conspicuously fail to consider the MFJ's deleterious effect on consumer welfare.

32. See, e.g., MACAVOY, supra note 17, at 31-34.

33. All other ILECs, except the BOCs, have been permitted to provide long-distance service. Indeed, SNET, the local telephone company in Connecticut, which for historic reasons was not considered a BOC by the MFJ, has been quite successful in providing long-distance service at generally lower prices than AT\&T has offered to Connecticut residential customers. 
networks to allow competing firms to use network elements to provide competition in local telephony.

\section{Bell Company Provision of Long-Distance Services}

The Telecommunications Act of 1996 superseded the MFJ and other federal regulation, but $\S 271$ of the newly amended Communications Act continued the interLATA line-of-business restriction in the form of a complex "checklist" process that required, among other things, that the RBOCs provide unbundled access to their local exchange networks as a quid pro quo for entry into interLATA telecommunications. ${ }^{34}$ Such a bargain was unnecessary. Economic efficiency and consumer well-being justified the rapid removal of the remaining line-of-business restrictions imposed on the RBOCs. Moreover, because the 1996 legislation expressly mandated unbundled access to the local network for competitors, it was superfluous to retain the regulatory quarantine as a bargaining chip for regulators.

Indeed, the $\S 271$ checklist procedure imposes more onerous burdens than the MFJ's interLATA restrictions ever did. ${ }^{35}$ Before a RBOC undergoes scrutiny under the checklist, it first must enter into an interconnection agreement, approved by the state public utilities commission (PUC) in the state in which the RBOC seeks to originate interLATA calls, with a facilitiesbased provider of local exchange service. ${ }^{36}$ Then the FCC, in consultation with the relevant state PUC, determines whether the RBOC's interconnection agreement satisfies the fourteen requirements of the checklist. If the interconnection agreement passes the checklist, and if the RBOC has established a structurally separate entity for the provision of in-region interLATA service, then the FCC must rule on the RBOC's request to provide in-region interLATA service ${ }^{37}$ pursuant to the general public-interest standard of the Telecommunications Act. ${ }^{38}$

Although the FCC must approve or reject the RBOC's application within ninety days, the complexity of the checklist and the related approval

34. See 47 U.S.C.A. \& 271(c)(2)(B) (West Supp. 1999).

35. Compare PETER W. HuBER ET AL., THE Telecommunications ACt OF 1996: SPECIAL. REPORT 32-33 (1996) (describing the requirements a Bell company must now mect to receive interexchange relief under the Act), with MACAvOY, supra note 17, at 190-200 (describing companies' experiences with the interLATA restrictions before the Telecommunications Act of 1996).

36. See 47 U.S.C.A. $\$ 271$ (c)(1)(A). Alternatively, if the state PUC had approved a generic interconnection plan offered by the RBOC, but the RBOC had received no request for interconnection within the first seven months after enactment of the Telecommunications Act of 1996 , then the RBOC would have been entitled to be evaluated under the checklist. See id. $\S 271(\mathrm{c})(\mathrm{I})(\mathrm{B})$.

37. See id. § $271(\mathrm{~d})(3)$.

38. Commands to honor the "public interest" pervade the Telecommunications Act of 1996. It has long been recognized that advancing the "public interest" is the touchstone of telecommunications regulation in the United States. See generally sources cited supra note 12. 
process has produced time-consuming disputes on matters of fact, law, economics, and engineering. That complexity-along with the provision authorizing the FCC to suspend or revoke its approval of the RBOC's provision of in-region interLATA service and the related provision creating a process for the filing of complaints by private parties upon which the FCC must act within ninety days $\mathrm{s}^{39}$-creates a rich opportunity for strategic gaming by interexchange carriers seeking to block RBOC entry into long-distance markets. The costs generated by the delay in obtaining waivers of the MFJ's line-of-business restrictions indicate the kinds of costs that consumers could incur under the similar quarantine approach of the checklist. The process of construing and applying the checklist will fuel extensive litigation. Because the outcome of such litigation will determine when a RBOC will be allowed to compete in lucrative interLATA markets, one can expect incumbent interexchange carriers to contest the litigation fiercely.

Most students of telecommunications agree that customers want some degree of one-stop shopping. AT\&T, MCI-WorldCom, and Sprint have all stated publicly that they believe one-stop shopping to be important competitively. BOC entry into long-distance service will permit the BOCs to offer one-stop shopping to compete with AT\&T, MCI-WorldCom, Sprint, and other companies. Increased choice makes consumers better off, so they will benefit from BOC entry into long-distance service. Increased choice will not be the only consumer effect of BOC entry, however. Lower long-distance prices and increased long-distance competition will be the main benefit. In a market of about $\$ 70$ billion per year, price decreases will create consumer benefits in the billions of dollars each year.

Moreover, BOC entry into long-distance service will increase the economic incentives and the ability of interexchange carriers (IXCs) to begin to offer local services. BOC entry will remove restrictions on AT\&T, MCI-WorldCom, Sprint, and other IXCs from bundling resold local services with their long-distance services. The removal of bundling restrictions will increase the expected economic return to IXCs from offering local services. Also, once the BOCs begin to offer bundled packages of local and long-distance services, IXCs will have to respond competitively with similar bundled packages of local and long-distance services. Increased competition by BOCs in long-distance markets will benefit consumers through lower long-distance prices and through one-stop bundled packages of local and long-distance services offered by the BOCs and by the IXCs. The goal of increased competition of the Telecommunications Act of 1996 will be furthered because competition will increase in both long-distance and local markets.

39. See 47 U.S.C.A. $§ 271(\mathrm{~d})(6)(B)$. 
An additional benefit of BOC entry will be the ability of the BOCs to engage in joint marketing of local, long-distance, and mobile packages. The ability to market jointly will also increase competition in both local markets (where IXCs and other competitors will be required by competition to respond with competitive offerings) and in long-distance and mobile markets (where, again, competitive offerings will expand and prices will decrease). The current policy restricting bundled offerings and joint marketing is a restriction on competition by regulation, which is harming consumers $^{40}$ and has produced what Paul MacAvoy has dubbed "regulation's rendition of Waiting for Godot." 41

\section{Competition in Local Telephony}

Sections 251 and 252 of the Communications Act, added by the Telecommunications Act of 1996, are the core provisions by which Congress sought to open local telephone markets to competition. ${ }^{42}$ Those two sections address the pricing of unbundled access to the network of the ILEC.

The Act envisions three ways for a firm to enter local telephony. The first method is "interconnection." Under this scheme, a firm builds its own network and interconnects with the network of an ILEC, so that the entrant's customers can complete calls to the incumbent's customers. The ILEC would charge the entrant to complete a call originating on the entrant's network, and vice versa. The relevant policy question here is the amount of money each party should be able to charge the other for completing calls.

A firm can also enter local telephony through "resale," which means that the entrant buys from the ILEC, at wholesale price, the basic service provided to the customer. The entrant then retails that service to its customers under its own brand name, sometimes combining the service with other offerings. The size of the wholesale discount is the pertinent policy question under this scheme.

Finally, the third method of entry is through the leasing of unbundled network elements, the building blocks of the local network. The entrant can then build its own network à la carte by buying some inputs from the ILEC and procuring other inputs from rivals already in the market (such as local

40. Using a long-distance elasticity estimate of -0.723 and an economic model of AT\&T's price leadership in residential long-distance service, one of us has computed that BOC entry will decrease long-distance prices by at least $15 \%$ to $25 \%$. See Declaration of Professor Jerry A. Hausman, Second Application by BellSouth Corporation et al. for Provision of In-Region. InterLATA Services in Louisiana, FCC 98-121, 15 (filed July 9, 1998) (on file with The Yale Law Journal).

41. MACAVOY, supra note 17 , at 176.

42. 47 U.S.C.A. $\$ \S 251-252$. In addition, Congress abolished any remaining legal barriers to entry: "No State or local statute or regulation, or other State or local legal requirement, may prohibit or have the effect of prohibiting the ability of any entity to provide any interstate or intrastate telecommunications service." Id. § 253(a). 
transport services provided by competitive access providers) or directly from equipment vendors (such as manufacturers of switches). This method of entry is known as "unbundling."

Sections 251 and 252 provide a skeleton for the pricing of interconnection, resale, and unbundling. ${ }^{33}$ Section 251 (c)(3) requires any ILEC (other than certain rural carriers) ${ }^{44}$ to offer competitors access to the ILEC's network elements on an unbundled basis. ${ }^{\text {ts }}$ In turn, § 251(d)(2) requires the FCC to consider, when determining whether to mandate the unbundling of an ILEC's network elements under $\$ 251$ (c)(3), “at a minimum, whether-(A) access to such network elements as are proprietary in nature is necessary; and (B) the failure to provide access to such network elements would impair the ability of the telecommunications carrier seeking access to provide the services that it seeks to offer." +6 Together, those two subsections are known as the "necessary" and "impair" requirements.

One cannot construe "necessary" and "impair" for purposes of $\S 251(d)(2)$ without first identifying the larger objective of the Telecommunications Act of 1996. The statute's preamble states that its purpose is to "promote competition and reduce regulation in order to secure lower prices and higher quality services for American telecommunications consumers and encourage the rapid deployment of new telecommunications technologies." ${ }^{47}$ In the legislative history, Congress reiterated that the objectives of the Telecommunications Act are "to provide for a pro-competitive, de-regulatory national policy framework designed to accelerate rapidly private sector deployment of advanced telecommunications and information technologies and services to all Americans by opening all telecommunications markets to competition." ${ }^{48}$

43. If the entrant and the ILEC cannot negotiate mutually acceptable terms of interconnection, resale, or unbundling, then the Telecommunications Act directs the state PUC to resolve the dispute through compulsory arbitration. See id. $\$ 252(b)$. By the fall of 1996, entrants and ILECs were unable to reach any voluntary agreements on the pricing of resale and unbundled network elements. As a consequence, hundreds of arbitration proceedings began in the fall of 1996. In most cases, each arbitration was a one-on-one proceeding between a single entrant and the IILEC.

44. See id. $\$ 251(f)$.

45. Section 251 (c)(3) provides that " [i]n addition to the duties contained in subsection [251(b)], each incumbent local exchange carrier" has certain other duties, including:

(3) Unbundled access. - The duty to provide, to any requesting telecommunications carrier for the provision of a telecommunications service, nondiscriminatory access to network elements on an unbundled basis at any technically feasible point on rates. terms, and conditions that are just, reasonable, and nondiscriminatory in accordance with the terms and conditions of the agreement and the requirements of this section and section 252 of this title. An incumbent local exchange carrier shall provide such unbundled network elements in a manner that allows requesting carriers to combine such elements in order to provide such telecommunications service.

Id. § 251(c)(3).

46. Id. $\$ 251(\mathrm{~d})(2)$.

47. Telecommunications Act of 1996, Pub. L. No. 104-104, pmbl., 110 Stat. 56. 56.

48. H.R. REP. NO. 104-458, at I (1996). 
By the plain language of $\S 251$ (c)(3), the "necessary" standard applies only to "such network elements as are proprietary in nature." 49 But neither $\S 251$ (d)(2) nor any other section of the Telecommunications Act of 1996 defines "proprietary" for purposes of the ILEC's duty to unbundle network elements. In practice, the "necessary" standard of $\$ 251(\mathrm{~d})(2)$ may ultimately prove to have less frequent application than the "impair" standard if, under whatever legal definition is adopted, an ILEC is deemed to have few or no network elements that are "proprietary in nature." One way to view the "necessary" standard is that the "impairment" standard sets necessary but not sufficient conditions for the mandatory unbundling of an element that is "proprietary in nature."

\section{The FCC's Interpretation of the Act's "Necessary" and "Impair" Requirements}

The FCC issued its Local Competition First Report and Order in August 1996, a 683-page directive that established pricing rules that the agency expected the states to follow and that provided definitions of "proprietary," "necessary," and "impair." ${ }^{00}$ The FCC concluded that proprietary network elements include those "elements with proprietary protocols or elements containing proprietary information." 51 The FCC defined a network element to be "necessary" when it is "a prerequisite for competition." ${ }^{2}$ The agency ruled that "in some instances, it will be 'necessary' for requesting carriers to obtain access to proprietary elements (e.g., elements with proprietary protocols or elements containing proprietary information), because without such elements their ability to compete would be significantly impaired or thwarted." 53 The FCC continued by contending that " $[r]$ equiring new entrants to duplicate unnecessarily even a part of the incumbent's network could generate delay and higher costs for new entrants. and thereby impede entry by competing local providers and delay competition, contrary to the goals of the 1996 Act." ${ }^{54}$ The FCC noted that ILECs "have economies of density, connectivity, and scale" that must "be shared with entrants." 55 Finally, the FCC relied on a literal dictionary definition of "impair," contending that it "means "to make or cause to become worse;

49. 47 U.S.C.A. $\S 251$ (d)(2)(A).

50. First Report and Order, Implementation of the Local Competition Provisions in the Telecommunications Act of 1996, 11 F.C.C.R. 15,499 (1996).

51. Id. \282. An ILEC's signaling protocols that adhere to Bellcore standards, however, were not proprietary in the FCC's view because they are industry-wide protocols. See id. $\mathbb{\text { I }} 481$.

52. Id. I 282 .

53. $I d$.

54. Id. 283.

55. Id. III. 
diminish in value." 56 The FCC further ruled that "generally ... an entrant's ability to offer a telecommunications service is 'diminished in value' if the quality of the service the entrant can offer, absent access to the requested element, declines and/or the cost of providing the service rises." 57

To effectuate its statutory interpretation of "necessary" and "impair," the FCC ordered in Rule 319 that an ILEC make seven UNEs available to a requesting telecommunications carrier: local loops, network interface devices (NIDs), local switching, interoffice transmission facilities, signaling networks and call-related databases, operations support systems (OSS), and operator services (OS) and directory assistance (DA). ${ }^{58}$

On review, the Court of Appeals for the Eighth Circuit affirmed Rule 319 as a reasonable agency interpretation, under the Chevron doctrine, ${ }^{39}$ of the "necessary" and "impair" standards of $\S 251$ (d)(2). ${ }^{60}$ The Supreme Court granted certiorari on that and other questions. ${ }^{61}$

\section{THE SUPREME COURT ON “NECESSARY" AND "IMPAIR"}

Nearly three years after Congress enacted the Telecommunications Act, the Supreme Court, in AT\&T Corp. v. Iowa Utilities Board, ${ }^{62}$ struck down as arbitrary and capricious Rule 319's implementation of the network element unbundling provisions contained in $\S 251(\mathrm{c})(3){ }^{63}$ The FCC's 1996 order announced, among other things, the minimum list of network elements that incumbent local exchange carriers must offer to other telecommunications carriers on an unbundled basis pursuant to the newly enacted $\S 251$ (c)(3) and $\S 251$ (d)(2). Specifically, the Court directed the FCC, on remand, to "determine on a rational basis which network elements must be made available, taking into account the objectives of the Act and giving some substance to the 'necessary' and 'impair' requirements."

56. Id. 285 (quoting RANDOM HOUSE COLLEGE DiCTIONARY 665 (rev. ed. 1984)).

57. Id. 9285.

58. See id. 9366 (to have been codified at 47 C.F.R. $\$ 51.319$ ).

59. See Chevron U.S.A. v. Natural Resources Defense Council, 467 U.S. 837, 843-44 (1984) (giving "controlling weight" to regulations devised by agencies pursuant to a congressional grant of authority "unless they are arbitrary, capricious or manifestly contrary to the statute"). See generally STEPHEN G. BREYER ET AL., ADMINISTRATIVE LAW AND REGULATORY POLICY: PROBLEMS, TEXT, AND CASES 256-57 (4th ed. 1999) (explaining Chevron).

60. See Iowa Utils. Bd. v. FCC, 120 F.3d 753, 810-12 (8th Cir. 1997), rev'd in part and aff d in part sub nom. AT\&T Corp. v. Iowa Utils. Bd.. 119 S. Ct. 721 (1999).

61. See FCC v. Iowa Utils. Bd., 118 S. C. 683 (1998). The other grounds for appeal included the fact that state PUCs, and not the FCC, had jurisdiction to promulgate these rules, and that the substantive pricing standards that the FCC had adopted were so low as to effect an uncompensated taking of the property of ILECs in violation of the Fifth Amendment.

62. 119 S. Ct. 721 .

63. See 47 U.S.C.A. \& 251(c)(3) (West Supp. 1999). The Coun, however, affirmed other aspects of the First Report and Order, including provisions relating to the pricing of unbundled network elements. See Iowa Utils. Bd., 119 S. Ct. at 732-33.

64. Iowa Utils. Bd., 119 S. Ct. at 736. 


\section{A. Justice Scalia's Opinion for the Court}

Writing for the Court, Justice Scalia regarded the unbundling provisions of the Telecommunications Act of 1996 as reflecting Congress's belief that local telephony is not a "natural monopoly," and that "[t]echnological advances... have made competition among multiple providers of local service seem possible." ${ }^{65}$ But from that congressional concern, Justice Scalia reasoned, it did not follow that the Telecommunications Act gave the FCC unlimited authority to compel ILECs to share their facilities with competitors.

Justice Scalia observed that $\S 251$ (d)(2) imposes "clear limits" on the FCC's authority to determine whether an ILEC must unbundle a particular network element pursuant to $\S 251$ (c)(3), and that Rule 319 exceeded the bounds of those clear limits. ${ }^{66}$ Justice Scalia wrote for the Court that "the FCC did not adequately consider the 'necessary and impair' standards when it gave blanket access to these network elements, and others, in Rule 319." ${ }^{67}$

The Court considered, but did not rule on, the relevance of the essential facilities doctrine in antitrust law as a limiting principle for the FCC's correct interpretation of the "necessary" and "impair" standards. Justice Scalia wrote:

The incumbents argue that $\S 251$ (d)(2) codifies something akin to the "essential facilities" doctrine of antitrust theory, opening up only those "bottleneck" elements unavailable elsewhere in the marketplace. We need not decide whether, as a matter of law, the 1996 Act requires the FCC to apply that standard; it may be that some other standard would provide an equivalent or better criterion for the limitation upon network-element availability that the statute has in mind. But we do agree with the incumbents that the Act requires the FCC to apply some limiting standard, rationally related to the goals of the Act, which it has simply failed to do. ${ }^{68}$

The Court found that Rule 319 lacked such a limiting principle, either with respect to "necessary" or "impair."

With respect to "necessary," Justice Scalia observed that "the Commission announced that it would regard the 'necessary' standards as having been met regardless of whether 'requesting carriers can obtain the requested proprietary element from a source other than the incumbent." ${ }^{69}$ Justice Scalia did not pause to elaborate on the fallacy of the FCC's reasoning.

65. Id. at 726 .

66. Id. at 738 .

67. Id. at 734 .

68. Id. at 734-35 (emphasis added) (citation omitted).

69. Id. at 735 (quoting First Report and Order, Implementation of the Local Competition Provisions in the Telecommunications Act of 1996, 1 I F.C.C.R. 15,499, $\mathbb{2 8 3}$ (1996)). 
Rather, he immediately proceeded to explain why, with respect to "impair," it was erroneous for the FCC to

regard the "impairment" standard as having been met if "the failure of an incumbent to provide access to a network element would decrease the quality, or increase the financial or administrative cost of the service a requesting carrier seeks to offer, compared with providing that service over other unbundled elements in the incumbent LEC's network," - which means that comparison with self-provision, or with purchasing from another provider, is excluded. ${ }^{70}$

In the Court's assessment, the FCC had created a tautology: "Since any entrant will request the most efficient network element that the incumbent has to offer, it is hard to imagine when the incumbent's failure to give access to the element would not constitute an 'impairment' under this standard." 71 Moreover, in the process, the FCC had assigned to potential entrants the critical determination that Congress had delegated to the agency through its enactment of $\S 251$ (d)(2):

The Commission asserts that it deliberately limited its inquiry to the incumbent's own network because no rational entrant would seek access to network elements from an incumbent if it could get better service or prices elsewhere. That may be. But that judgment allows entrants, rather than the Commission, to determine whether access to proprietary elements is necessary, and whether the failure to obtain access to nonproprietary elements would impair the ability to provide services. ${ }^{72}$

In seeking to implement the unbundling provisions of the 1996 legislation, the FCC had created a process that would, in effect, be controlled by the access seekers themselves.

The Court also criticized, on two grounds, the economic reasoning underlying the FCC's interpretation of "necessary" and "impair." Those two errors of economic logic translated into two reversible legal errors in the agency's interpretation of $\S 251$ (d)(2). First, the FCC had ignored the relevance of supply substitutability. The Court found that, in determining the list of elements that ILECs must provide on an unbundled basis pursuant to $\S 251(\mathrm{c})(3)$ and $\S 251$ (d)(2), the FCC must consider the availability of network elements outside the incumbent's network: "The Commission cannot, consistent with the statute, blind itself to the

70. Id. (quoting First Report and Order, II F.C.C.R. $\ 285$ (emphasis added by the Court)) (citation omitted).

71. Id.

72. Id. 
availability of elements outside the incumbent's network. That failing alone would require the Commission's rule to be set aside." ${ }^{73}$

Second, Justice Scalia emphasized that the "impairment" standards must embody some threshold of materiality. Otherwise, "impairment" could be said to result from the slightest difference between what the ILEC implicitly paid itself for use of a particular network element and what the requesting carrier would pay for it as a UNE. "Impairment" similarly could be said to result from any difference in the quality of the network element:

[T]he Commission's assumption that any increase in cost (or decrease in quality) imposed by denial of a network element renders access to that element "necessary," and causes the failure to provide that element to "impair" the entrant's ability to furnish its desired services is simply not in accord with the ordinary and fair meaning of those terms. An entrant whose anticipated annual profits from the proposed service are reduced from $100 \%$ of investment to $99 \%$ of investment has perhaps been "impaired" in its ability to amass earnings, but has not ipso facto been "impair[ed]... in its ability to provide the services it seeks to offer"; and it cannot realistically be said that the network element enabling it to raise its profits to $100 \%$ is "necessary." 74

In articulating that legal and economic reasoning for the Court, Justice Scalia responded to Justice Souter's dissent, which argued that the common usage of the words "necessary" and "impair" made Rule 319 a reasonable agency interpretation of $\$ 251$ (d)(2) to which the Court should defer under Chevron." Justice Scalia's response to Justice Souter made two important points, one concerning an incumbent's cost advantage over entrants, and the other concerning whether an entrant was entitled to expect anything more than a reasonable opportunity to earn a competitive return:

Justice Souter points out that one can say his ability to replace a light bulb is "impaired" by the absence of a ladder, and that a ladder is "necessary" to replace the bulb, even though one "could stand instead on a chair, a milk can, or eight volumes of Gibbon." True enough (and nicely put), but the proper analogy here, it seems to us, is not the absence of a ladder, but the presence of a ladder tall enough to enable one to do the job, but not without stretching one's arm to its full extension. A ladder one-half inch taller is not,

73. Id.

74. $I d$.

75. See id. at 739 (Souter, J., concurring in part and dissenting in part). 
"within an ordinary and fair meaning of the word," "necessary," nor does its absence "impair" one's ability to do the job. ${ }^{76}$

Justice Scalia also emphasized that the statutory right of competing telecommunications carriers to receive unbundled access to an ILEC's network element under the "impairment" standards was not a guarantee to the carrier of supracompetitive profits: "We similarly disagree with Justice Souter that a business can be impaired in its ability to provide serviceseven impaired in that ability 'in an ordinary, weak sense of impairment'when the business receives a handsome profit but is denied an even handsomer one." 77 Stated differently, Justice Scalia reasoned that, if a telecommunications carrier does not need to lease a particular UNE to earn a normal economic profit after entering a particular market, then that carrier cannot claim to have been "impaired" in its ability to supply telecommunications services to consumers simply because its lease of the UNE in question might have enabled the carrier to earn a supracompetitive profit. Consistent with the view that the unbundling rules exist to enhance consumer welfare rather than competitor welfare, Justice Scalia seemed to say that a CLEC could have at most a legally cognizable claim under the "necessary" and "impair" standards only if it would be denied, by an ILEC's refusal to offer the desired UNE, a reasonable opportunity to eam a competitive return on capital, or what is called zero economic profit. ${ }^{78}$ The mandatory unbundling provisions of $\S 251$ (d)(2) do not grant an entrant any right to earn a supracompetitive return, or what is called economic rent. "In a world of perfect competition," wrote Justice Scalia, "in which all carriers are providing their service at marginal cost, the Commission's total equating of increased cost (or decreased quality) with 'necessity' and 'impairment' might be reasonable; but it has not established the existence of such an ideal world." ${ }^{80}$ Justice Scalia saw no statutory basis for the distortions that Rule 319 would create in an imperfect world-let alone the distortions that the FCC would create by ensuring that entrants would earn windfall profits if they chose to lease, at a TELRIC price, any network element for which the FCC had found it to be technically feasible to order mandatory unbundling.

76. Id. at $735 \mathrm{n} .11$ (quoting id. at 739 (Souter, J., concurring in part and dissenting in par)) (citation omitted).

77. Id. (quoting id. at 740 (Souter, J., concurring in part and dissenting in part)) (citation omitted).

78. "Economic profits are zero when total revenues equal total costs, inclusive of a competitive retum on capital." SIDAK \& SPULBER, supra note 4, at 313.

79. Economic rent is a return to a factor of production in excess of the payment that is necessary to prevent that factor from being redeployed to an alternative use. See, e.g.. PaUL. MILGROM \& JOHN ROBERTS, ECONOMICS, ORGANIZATION AND MANAGENENT 269 (1992): Armen A. Alchian, Rent, in 4 THE New PaLgRaVE: A Dictionary of ECONOMICS 141 (John Eatwell et al. eds., 1987).

80. Iowa Utils. Bd., 119 S. Ct. at 735. 
The Court found that the FCC's interpretations of "necessary" and "impair" produced a more invasive approach to mandatory network unbundling than the Court believed Congress possibly could have intended:

We cannot avoid the conclusion that, if Congress had wanted to give blanket access to incumbents' networks on a basis as unrestricted as the scheme the Commission has come up with, it would not have included $\S 251$ (d)(2) in the statute at all. It would simply have said (as the Commission in effect has) that whatever requested element can be provided must be provided. ${ }^{81}$

The Court traced that error in the FCC's statutory interpretation to the agency's conclusion that it would impair entry for the ILEC to fail to unbundle every network element for which unbundling was technically feasible:

The FCC was content with its expansive methodology because of its misunderstanding of $\S 251(c)(3)$, which directs an incumbent to allow a requesting carrier access to its network elements "at any technically feasible point." The Commission interpreted this to "impos[e] on an incumbent LEC the duty to provide all network elements for which it is technically feasible to provide access," and went on to "conclude that we have authority to establish regulations that are coextensive" with this duty. ${ }^{82}$

Justice Scalia observed that this interpretation was "undoubtedly wrong," as the Eighth Circuit had held. ${ }^{83}$ Quoting the Eighth Circuit's decision, the Court emphasized that $\S 251(c)(3)$ "indicates 'where unbundled access must occur. not which [network] elements must be unbundled." ${ }^{84}$ The FCC, however, adopted a contrary interpretation in its Local Competition First Report and Order: "The Commission began with the premise that an incumbent was obliged to turn over as much of its network as was 'technically feasible,' and viewed [ $\S 251(d)(2)]$ as merely permitting it to soften that obligation by regulatory grace...." 85

81. Id.

82. Id. at 736 (quoting First Report and Order, Implementation of the Local Competition Provisions in the Telecommunications Act of 1996, 11 F.C.C.R. 15,499, 1278 (1996) (emphasis added by the Court)); see also id. (" [W]e conclude that the statute does not require us to interpret the 'impairment' standard in a way that would significantly diminish the obligation imposed by section 251(c)(3)." (quoting First Report and Order, II F.C.C.R. 1286 )).

83. $I d$.

84. Id. (quoting Iowa Utils. Bd. v. FCC, 120 F.3d at 810 (emphasis added by the Court)).

85. Id. (citation omitted). As evidence of that erroneous premise, Justice Scalia quoted the following language from the Local Competition First Report and Order: "To give effect to both sections 251 (c)(3) and 251 (d)(2), we conclude that the proprietary and impairment standards in section 251 (d)(2) grant us the authority to refrain from requiring incumbent LECs to provide all 
The Court ruled that the FCC's "premise was wrong" and that $\S 251$ (d)(2) "does not authorize the Commission to create isolated exemptions from some underlying duty to make all network elements available." 86 Far from intending the FCC's discretionary dispensation of "regulatory grace," $\S 251(d)(2)$

requires the Commission to determine on a rational basis which network elements must be made available, taking into account the objectives of the Act and giving some substance to the "necessary" and "impair" requirements. The latter is not achieved by disregarding entirely the availability of elements outside the network, and by regarding any "increased cost or decreased service quality" as establishing a "necessity" and an "impair[ment]" of the ability to "provide ... services." 87

In short, the Court held that the FCC's interpretation of "necessary" and "impair" must reflect the procompetitive goals of the 1996 legislation, that the interpretation must embody an assessment of competitive substitution in the supply of network elements, and that the interpretation must not trigger mandatory unbundling of network elements on the basis of insignificant differences between the cost or service quality of the network elements used by the ILEC and the cost or service quality of the network elements that the ILEC supplies an entrant.

\section{B. Justice Breyer's Concurring Opinion}

Justice Breyer wrote a separate opinion in Iowa Utilities Board that concurred with the Court's holding on the "necessary" and "impair" standards. ${ }^{88}$ Unlike Justice Scalia, whose opinion for the Court confined itself to interpretation of statutory text, Justice Breyer began with the premise that the "statute's history and purpose can illuminate its language." ${ }^{89}$ Accordingly, Justice Breyer read the "necessary" and "impair" requirements not only "in light of history, purpose, and

network elements for which it is technically feasible to provide access on an unbundled basis." Id. (quoting First Report and Order, 11 F.C.C.R. 9 279).

86. Id.

87. Id. Justice Thomas concurred with this part of the Court's decision but wrote a separate opinion, joined by Chief Justice Rehnquist and Justice Breyer, which dissented from other parts of the Court's decision that are not pertinent to our discussion. See id. at 741-46 (Thomas, J.. concurring in part and dissenting in part).

88. Id. at 746-54 (Breyer, J., concurring in part and dissenting in part). Much of Justice Breyer's opinion was devoted to his dissent from the Court's holding concerning the FCC's jurisdiction to promulgate pricing rules that were binding on the states.

89. Id. at 746. For historical analysis, Justice Breyer relied upon Justice Thomas's opinion. 
precedent," ${ }^{90}$ but also in light of scholarly research on the law and economics of regulation and antitrust jurisprudence. ${ }^{91}$

\section{The Purpose of the Telecommunications Act}

Unlike Justice Scalia, Justice Breyer presented the litigation over unbundling and UNE pricing as the current act of a long drama, commencing with the divestiture of AT\&T. The federal government had used the prospect of lifting the regulatory quarantine on RBOCs entering interLATA markets to induce the RBOCs to open their local exchange markets to competitive entry-by, among other possible firms, the IXCs. ${ }^{92}$ Justice Breyer acknowledged that the government's use of a barrier to entry into one market as a lever to promote entry into another market created costs-diminished interLATA competition-that had to be balanced against the perceived benefits of stimulating competition in local telephony. In the Telecommunications Act, he observed, Congress codified its judgment concerning the proper tradeoff between competitive benefits and costs. ${ }^{93}$

To advance toward competition in local telephony, Justice Breyer observed that the 1996 legislation poses, but "does not purport to answer," an empirical question: "To what extent is local competition possible without wasteful duplication of facilities?" ${ }^{94}$ The Telecommunications Act "creates a set of legal rules," including unbundling rules, "which, through interaction with the marketplace, aims to produce sensible answers." Justice Breyer summarized Congress's logic in enacting the local competition and long-distance provisions of the Telecommunications Act as follows:

[O]ne can understand the basic logic of "unbundling" by imagining that Congress required a sole incumbent railroad providing service between City A and City B to share certain basic facilities, say, bridges, rights-of-way, or tracks, in order to avoid wasteful duplication of those hard-to-duplicate resources while facilitating competition in the remaining aspects of A-to-B railroad service. Indeed, one might characterize the Act's basic purpose as seeking to bring about, without inordinate waste, greater local service competition both as an end in local markets and as a means

90. Id.

91. Justice Breyer, of course, has made his own contributions to that scholarly literature. See. e.g., STEPHEN G. BREYER, REGULATION AND ITS REFORM (1982); Breyer, supra note 9. part).

92. See Iowa Utils. Bd., 119 S. Ct. at 746-47 (Breyer, J., concurring in part and dissenting in

93. See id. at 747.

94. Id.

95. Id. (citing 47 U.S.C.A. \$§ 251(c)(2)-(4). 253(a) (West Supp. 1999)). 
towards more competition, and fair competition, in long-distance markets. ${ }^{96}$

Justice Breyer believed that " $[\mathrm{t}]$ hose purposes neither require nor suggest reading the Act's language to change radically the scope of local regulators' traditional rate-setting powers." 97 His basis for that view has equal applicability to the "necessary" and "impair" standards of $\S 251(d)(2)$, an issue on which Justice Breyer concurred with six other Justices: ${ }^{95}$

The introduction of competition into a particular locality does not diminish the importance of place-specific factors, such as local history, geography, demands, and costs. And local regulators are likely more familiar than are national regulators, for example, with a particular utility's physical plant, its cost structure, the pattern of local demand, the history of local investment, and the need for recovery of undepreciated fixed costs.

Moreover, local regulators have experience setting rates that recover both the immediate, smaller, added costs that demand for additional service imposes upon a local system and also a proper share of the often huge fixed costs (of local loops, say, or switches) and overhead needed to provide the dial tone itself. Indeed, local regulators would seem as likely, if not more likely, than national regulators to know whether, when, or the extent to which, particular local charges or systems of charges will lead new entrants to abandon efforts to use a local incumbent's elements, turning instead to alternative technologies. And local regulators would seem as likely as national regulators to know whether or when use of such alternative technologies in the local circumstances will prove more beneficial than wasteful. It is the local communities, and, hence, local regulators, that will directly confront the problems and enjoy the benefits associated with local efforts to integrate new and old communications resources and communications firms. ${ }^{99}$

As we shall explain in Section VII.B, this insight concerning the unique competence of state regulators in evaluating the competitive and regulatory aspects of local telecommunications markets has special relevance to the FCC's 1999 proposal in the Second Further Proposed Notice of Rulemaking to preempt state participation in the interpretation and administration of $\S 251(\mathrm{~d})(2)$ by announcing, on a nationwide basis, that certain unbundled network elements are deemed to meet the "necessary" and "impair" requirements.

\footnotetext{
96. Id. at 748 .

97. Id.

98. Justice O'Connor did not participate in the case. See id. at 721.

99. Id.
} 


\section{The FCC's Pricing Rules for Unbundled Network Elements}

Much of Justice Breyer's separate opinion addressed his disagreement with the majority over whether the Telecommunications Act gave the FCC the authority to preempt state rate-setting for unbundled network elements. Although most of that analysis is not directly relevant to interpreting the "necessary" and "impair" requirements, some portions unquestionably are. In particular, Justice Breyer emphasized that, "when faced with ambiguity" in a regulatory statute that envisions federal and state cooperation, the Court is "to interpret statutes... on the assumption that Congress intended to preserve local authority." 100 Justice Breyer observed that the "dozens of pages of text that set... forth" the FCC's pricing rules for unbundled network elements were "highly specific and highly detailed." ${ }^{101}$ Their effect was to deny any discretion to state regulators:

[The FCC's pricing rules] deprive state commissions of methodological leeway. Their rate-setting instructions grant a state commission little or no freedom to choose among reasonable ratedetermining methods according to the State's policy-related judgments, assessing local economic circumstance or community need. I grant the fact that the rules leave it to the state commissions to fix the actual rate, but that is rather like giving a restaurant chef the authority to choose a menu while restricting him to one dish, an omelette, and to one single favorite recipe. ${ }^{102}$

Furthermore, Justice Breyer noted, the Telecommunications Act did not compel the pricing rule that the FCC imposed on the states. ${ }^{103}$ He regarded the FCC's vision of competition as misguided: "The competition that the Act seeks is a process, not an end result; and a regulatory system that imposes through administrative mandate a set of prices that tries to mimic those that competition would have set does not thereby become any the less a regulatory process, nor any the more a competitive one." ${ }^{104}$ As we shall explain in Part IV, this misconception of competition directly affects the FCC's interpretation of the "necessary" and "impair" standards as well.

In the context of UNE pricing, Justice Breyer intimated that the FCC's strategy in preempting the states from developing their own pricing rules was to foreclose other reasonable interpretations of the statute without part).

100. Iowa Utils. Bd., $119 \mathrm{~S}$. Ct. at 749-50 (Breyer, J., concurring in part and dissenting in

101. Id. at 751 (citing First Report and Order, Implementation of the Local Competition Provisions in the Telecommunications Act of 1996, 11 F.C.C.R. 15,499, 19 672-715 (1996)).

102. Id.

103. See id. ("Nor can the FCC successfully argue that the Act requires the particular ratesetting system that its regulations contain.").

104. Id. 
having to supply an intellectually respectable justification for that exclusion: "Most importantly, the FCC's rules embody not an effort to circumscribe the realm of the reasonable, but rather a policy-oriented effort to choose among several different systems, including systems based upon actual costs or price caps, which other systems the FCC's rules prohibit," 105 Those alternative pricing rules, prohibited by the FCC, "illustrate ... how easily a regulator weighing certain policy considerations (for example administrative considerations) differently might have chosen a different set of reasonable rules." 106 One could imagine state regulators similarly adopting conclusions about "necessity" and "impairment" that differ reasonably from the FCC's conclusions.

\section{The "Necessary" and "Impair" Requirements}

Justice Breyer concurred in the Court's holding with respect to the FCC's interpretation of the "necessary" and "impair" requirements of $\S 251$ (d)(2). In writing separately on this part of the Court's decision, he employed economic analysis that complemented the textual analysis of Justice Scalia's majority opinion.

Justice Breyer began by noting that the Telecommunications Act expresses the unbundling obligations of ILECs " in general terms, reflecting congressional uncertainty about the extent to which compelled use of an incumbent's facilities will prove necessary to avoid waste." 107 He then anticipated the question, which we address in Part IV, that goes to the heart of the issue confronting the FCC on remand: "Will wireless technology or cable television lines, for example, permit the efficient provision of local telephone service without the use of existing telephone lines that now run house to house?" 108 Such substitution at the end-user level has the potential, over the near term in some geographic markets, to render mandatory unbundling of even residential local loops unnecessary and inappropriate.

Justice Breyer found the "reasonably clear" objective of $\$ 251$ (d)(2) to be "to facilitate the introduction of competition where practical, i.e.,

105. Id.

106. Id. at 752. With respect to the "the FCC"s decision to prohibit use" of the efficient component-pricing rule (ECPR), Justice Breyer noted: "The FCC rejected that [ECPR] system. but in doing so it did not claim, nor did its reasoning support the claim, that the use of such a system would be arbitrary or unreasonable." Id. Of "the FCC"s decision to forbid the use" of Ramsey pricing, Justice Breyer wrote: "Many experts strongly prefer the use of such a system [and some argue] that the FCC's prohibition of Ramsey pricing will 'minimize rather than maximize consumer welfare.' The FCC disfavors Ramsey pricing, but it does not explain why a contrary judgment would conflict with the statute or otherwise be arbitrary or unreasonable." Id. (quoting Sidak \& Spulber, supra note 4, at 1109 , and citing I ALFRED E. KAHN, THE ECONOMICS OF REGULATION: PRINCIPLES AND INSTTIUTIONS 137-41 (rev. ed. 1988)).

107. Id at 753.

108. Id. 
without inordinate waste." 109 That objective, he reasoned, required $\S 251(d)(2)$ to function like the essential facilities doctrine in antitrust law:

[A]lthough the provision describing which elements must be unbundled does not explicitly refer to the analogous "essential facilities" doctrine (an antitrust doctrine that this Court has never adopted), the Act, in my view, does impose related limits upon the FCC's power to compel unbundling. In particular, I believe that, given the Act's basic purpose, it requires a convincing explanation of why facilities should be shared (or "unbundled") where a new entrant could compete effectively without the facility, or where practical alternatives to that facility are available. ${ }^{110}$

Justice Breyer noted that Justice Scalia reached this insight by textual analysis. ${ }^{111}$ The great utility of Justice Breyer's concurrence on the unbundling rules is that he went beyond the majority's textual analysis to suggest that the kind of consumer welfare analysis that a court routinely conducts in an antitrust case also would yield the same answer: Section 251 (d)(2) must be implicitly limited by a principle that resembles the essential facilities doctrine.

Justice Breyer emphasized that, in multiple respects, unbundling is not costless to private firms, consumers, or regulators:

The fact that compulsory sharing can have significant administrative and social costs inconsistent with the Act's purposes suggests [that a limiting principle implicitly exists.] Even the simplest kind of compelled sharing, say, requiring a railroad to share bridges, tunnels, or track, means that someone must oversee the terms and conditions of that sharing. Moreover, a sharing requirement may diminish the original owner's incentive to keep up or to improve the property by depriving the owner of the fruits of value-creating investment, research, or labor. ${ }^{112}$

Furthermore, Justice Breyer warned that the complexity and cost of mandatory unbundling multiply as the network elements in question become more technologically sophisticated and as product or process innovation becomes a more significant dimension over which firms compete in the provision of end services:

And as one moves beyond the sharing of readily separable and administrable physical facilities, say, to the sharing of research

109. Id.

110. Id.

111. See id. ("[T]he Act's language itself suggests some such limits.").

112. Id. 
facilities, firm management, or technical capacities, these problems can become more severe. One would not ordinarily believe it practical, for example, to require a railroad to share its locomotives, fuel, or workforce. Nor can one guarantee that firms will undertake the investment necessary to produce complex technological innovations knowing that any competitive advantage deriving from those innovations will be dissipated by the sharing requirement. The more complex the facilities, the more central their relation to the firm's managerial responsibilities, the more extensive the sharing demanded, the more likely these costs will become serious.... And the more serious they become, the more likely they will offset any economic or competitive gain that a sharing requirement might otherwise provide. The greater the administrative burden, for example, the more the need for complex proceedings, the very existence of which means delay, which in turn can impede the entry into long-distance markets that the Act foresees. ${ }^{113}$

We examine these costs of mandatory unbundling in detail in Part IV.

Justice Breyer found further need for a limiting principle by examining the kinds of competition that would and would not emerge from mandatory unbundling:

Nor are any added costs imposed by more extensive unbundling requirements necessarily offset by the added potential for competition. Increased sharing by itself does not automatically mean increased competition. It is in the unshared, not in the shared, portions of the enterprise that meaningful competition would likely emerge. Rules that force firms to share every resource or element of a business would create, not competition, but pervasive regulation, for the regulators, not the marketplace, would set the relevant terms. ${ }^{114}$

Justice Breyer therefore reasons that $\S 251(\mathrm{~d})(2)$ requires balancing expected benefits and costs. ${ }^{115}$ According to Justice Breyer, "Regulatory rules that go too far, expanding the definition of what must be shared beyond that which is essential to that which merely proves advantageous to a single competitor, risk costs that, in terms of the Act's objectives, may make the game not worth the candle." 116 If Congress had intended through

113. Id. at 753-54 (citing 1 HAROLD DEMSETZ, OWNERSHIP. CONTROL, AND THE FIRN: THE ORGANIZATION OF ECONOMIC ACTIVITY 207 (1988)).

114. Id. at 754 .

115. See id. Justice Breyer's conclusion is consistent with his broader view that regulation should be subjected to rigorous cost-benefit analysis. See genterally STEPHEN BREYER. BREAKING THE VICIOUS CIRCLE: TOWARD EFFECTIVE RISK REGULATION (1993).

116. Iowa Utils. Bd., 119 S. Ct. at 754 (Breyer. J.. concurring in part and dissenting in par). 
its enactment of the Telecommunications Act of 1996 that "an incumbent should be forced to share virtually every aspect of its business," asked Justice Breyer, "would Congress have seen a need for a separate wholesale sales requirement (since the 'unbundling' requirement would have led to a similar result)? Indeed, would Congress have so emphasized the importance of competition?" 117 Justice Breyer concluded that the FCC's vision of the optimal level of unbundling-"the more the incumbent unbundles, the better" 118 -would create nothing more than a Potemkin village of competition: "A totally unbundled world-a world in which competitors share every part of an incumbent's existing system, including, say, billing, advertising, sales staff, and work force (and in which regulators set all unbundling charges)-is a world in which competitors would have little, if anything, to compete about." 119

\section{Justice Souter's Dissent}

In a separate opinion in Iowa Utilities Board, Justice Souter concurred in the Court's holding that the FCC had jurisdiction to set UNE pricing rules that bound the states, but he dissented from the Court's holding that the FCC unreasonably interpreted the "necessary" and "impair" requirements of $\S 251$ (d)(2). ${ }^{120}$ Justice Souter's dissent is significant because, of the four opinions by the Justices in Iowa Utilities Board, ${ }^{121}$ his most closely resembles the reasoning contained three months later in the FCC's Second Further Notice of Proposed Rulemaking.

Justice Souter predicated his analysis on the observation that " $[u]$ nder Chevron, the only question before us is whether the Commission's interpretation, obviously favorable to potential competitors, falls outside the bounds of reasonableness." ${ }^{122} \mathrm{He}$ conceded that Rule 319 would "probably allow a competitor to obtain access to any network element that it wants" by presenting at most "a weak economic justification." 123 As a matter of statutory interpretation, however, Justice Souter considered "necessary" and "impair" to be ambiguous words that Chevron entitled the FCC to define in any reasonable manner, including what he described as the "weak... [but] unquestionably still ordinary uses of the words" 124 that he illustrated with the

117. Id.

118. Id.

119. Id.

120. Id. at 739 (Souter, J., concurring in part and dissenting in part).

121. Justice Thomas wrote a dissenting opinion as well. See supra note 87.

122. lowa Utils. Bd., 119 S. Ct. at 739 (Souter, J., concurring in part and dissenting in part).

123. Id.

124. Id. at 740 . 
ladder-and-light-bulb example, commented upon by Justice Scalia. ${ }^{125}$ Unlike Justice Breyer, Justice Souter could perceive no social costs that would offset the perceived social benefits of greater degrees of unbundling. Justice Souter did not recognize that his interpretation of $\S 251(\mathrm{~d})(2)$ would place the unbundling rules at cross-purposes with the rest of the Telecommunications Act, as well as with the antitrust laws. Justice Souter's reasoning was rejected by every other member of the Court participating in the lowa Utilities Board decision.

\section{On Remand}

The FCC responded to the Court's opinion by issuing in April 1999 a Second Further Notice of Proposed Rulemaking. ${ }^{126}$ In this notice, the FCC affirmed its authority to issue a national list of minimum unbundling requirements, ${ }^{127}$ but appeared open to suggestions on the applicability of the "necessary" and "impair" standards to services embodying new technologies, as well as the applicability of the essential facilities doctrine to network unbundling. ${ }^{128}$ As in the case of any of the FCC's notices of proposed rulemaking, the agency announced numerous "tentative conclusions" concerning the network elements that might need to be unbundled and the reasoning leading to such conclusions. We examine the FCC's reasoning and conclusions in Part IV.

Meanwhile, as of November 1999, no BOC had received FCC permission to provide long-distance service-although Bell Atlantic's application to provide such service in New York, filed in October 1999, was reported to have a chance of approval before $2000 .{ }^{129}$ Long-distance companies (principally AT\&T, MCI-WorldCom, and Sprint) have opposed the prospect of increased competition in interLATA markets, and the FCC has attempted to wring greater unbundling concessions out of the BOCs. This stalemate, much like the MFJ, has harmed consumers, and the United States continues as the only developed country where (most) local telephone companies are not permitted to compete for long-distance traffic.

125. If I want to replace a light bulb, I would be within an ordinary and fair meaning of the word "necessary" to say that a stepladder is "necessary" to install the bulb. even though I could stand instead on a chair, a milk can, or eight volumes of Gibbon. I could just as easily say that the want of a ladder would "impair" my ability to install the bulb under the same circumstances.

Id. at 739. For Justice Scalia's comments, see supra text accompanying notes 75-77.

126. Second Further Notice of Proposed Rulemaking. supra note 3.

127. Id. I 14.

128. See id. 19 16-23.

129. See Steve Rosenbush, A Boom for the Baby Bells?. Bus. WK., Nov. I, 1999, at 47. 


\section{Why LIMITING PRINCIPLES ARE NEEDED}

In this Part, we will use economic analysis to identify the interpretations of the "necessary" and "impair" standards that best meet the goals of the Telecommunications Act of 1996. Foremost among those limiting principles is the proposition that the FCC's unbundling rules should regard the public interest as primarily determined by consumer welfare, which is advanced by competition rather than by the protection of any particular competitor's interests. Thus, whether it is "necessary" for the FCC to mandate, at TELRIC prices, the unbundling of a particular proprietary network element in a particular location at a particular time should depend on whether such unbundling is necessary to permit the competitive supply of telecommunications services to end users. Similarly, the correct meaning of "impair" for purposes of $\S 251$ (d)(2) is whether the ILEC's failure to unbundle, at TELRIC prices, a particular nonproprietary network element would produce an equilibrium supply of telecommunications services that would be, relative to the competitive equilibrium, significantly inferior for consumers. Here, "inferior" can mean not only higher prices, but also lower quality services or less innovation in new telecommunications services. The consumer welfare losses from such inferiority have been shown empirically to be enormous. ${ }^{130}$

\section{A. Consumer Welfare: Competition Rather than Competitor Protection}

The definitions of "necessary" and "impair" should seek to further overall competition and not merely the economic interests of individual competitors. In its Local Competition First Report and Order, the Commission failed to make that distinction, one well-recognized in antitrust law. Unfortunately, the FCC's 1999 Second Further Notice of Proposed Rulemaking repeats that error.

\section{The Goal of the Telecommunications Act}

Consumers benefit from competition because it leads to greater innovation and lower prices. Thus, the public interest is consistent with increased competition and innovation. However, the public-interest standard, although central to interpretation of telecommunications regulation, has not always received so precise a definition. Three years before the passage of the Telecommunications Act of 1996, Professor William J. Baumol and one of the present authors wrote:

130. See Hausman, supra note 12. 
[W]e will use the phrase "the public interest" more precisely and restrictively than do the Communications Act, the FCC, and the state public utility commissions. It will connote economic efficiency, or the maximization of the general welfare of consumers and producers-that is, the maximization of the sum of consumers' surplus and producers' surplus. Often this criterion is referred to in the abbreviated form "consumer welfare maximization." 131

The primacy that economists ascribe to economic efficiency and to the maximization of consumer welfare has a related benefit: It harmonizes economic regulation and antitrust law. For in the latter, the Supreme Court has contributed a muscular jurisprudence asserting that the first goal of the Sherman Act and other federal antitrust statutes is to be a "consumer welfare prescription." 132 This harmony between regulation and antitrust has three important implications. First, the same basic tools of microeconomic analysis can be employed in one as in the other. There can be little disagreement that the economic sophistication of antitrust law has enriched the regulatory analysis of natural monopolies. Second, changes in technology or other circumstances that permit a natural monopoly to give way to competition impart continuity to the relationship between economic regulation and antitrust. Third, many of the thorniest problems in antitrust law-such as judicial enforcement of injunctive remedies or the essential facilities doctrine-are fundamentally regulatory in nature, involving issues such as entry or the pricing of intermediate goods sold to competitors. Thus, the economic scholarship on regulation can in many instances enrich antitrust jurisprudence. ${ }^{133}$

In 1996, Congress endorsed this view when, as noted earlier, it emphasized in the Telecommunications Act that the improvement of consumer welfare was the new legislation's overarching purpose.

\section{Iowa Utilities Board}

A standard that looks to the effect on competition, rather than the interests of a given CLEC, comports with the Supreme Court's command that the Commission must take into account the availability of substitutes for ILEC network elements outside the ILEC's network. If substitutes outside the ILEC's network are available, that availability occurs because some firms have made the rational economic decision that they can efficiently provide services that employ those non-ILEC elements.

131. BAUMOL \& SIDAK, supra note 11 , at 26.

132. NCAA v. Board of Regents, 468 U.S. 85, 107 (1984); Reiter v. Sonolone Corp.. 442 U.S. 330, 343 (1979).

133. See BAUMOL \& SIDAK, supra note 11, at 26-27. 
Two conclusions necessarily follow. First, the element as provided by the ILEC cannot be essential for competition because competition is already occurring without ILEC provision. Thus, the network element, unbundled by government decree at TELRIC prices, cannot be labeled an essential facility, or "necessary" for competition, or an element for which the decision not to mandate unbundling at a TELRIC price would "impair" the competitive supply of telecommunications services. "Increased sharing," observed Justice Breyer, "by itself does not automatically mean increased competition." 134

Second, competition will not be adversely affected if a given CLEC cannot procure the unbundled element from the ILEC. Other firms are providing substitutes outside the ILEC's network, and so, in the absence of diminishing returns to scale, increased demand for the element outside the ILEC's network can be met at the same or lower economic cost. We would find diminishing returns to scale if a scarce input, which could not be reproduced, were present-fertile land is a good example. But in telecommunications those scarce inputs do not exist; in fact, the Commission itself states that increasing returns to scale are expected..$^{135}$

Therefore, the limiting principle sought by the Court emerges naturally from its analysis of substitutability. Although the Court did not explicitly endorse our consumer-welfare maximization principle, the Court's analysis clearly points in that direction.

\section{Consumer Welfare in Antitrust Jurisprudence}

Like the Telecommunications Act, modern antitrust law looks to consumer welfare as its guiding principle. Several respected jurists have elaborated this point. For example, Chief Judge Posner has repeatedly emphasized that consumer welfare is the guiding light of antitrust law, stressing that "[c]ompetition is the allocation of resources in which economic welfare (consumer welfare, to oversimplify slightly) is maximized; it is not rivalry per se, or a particular form of rivalry, or some minimum number of competitors." ${ }^{136}$ In a 1983 antitrust decision, he stated:

[T] hough there is a sense in which the exclusion of any competitor reduces competition, it is not the sense of competition that is relevant to antitrust law. The policy of competition is designed for the ultimate benefit of consumers rather than of individual

134. AT\&T v. Iowa Utils. Bd., 119 S. Ct. 721, 754 (1999) (Breyer, J., concurring in part and dissenting in part).

135. See Inquiry Concerning the Deployment of Advanced Telecommunications Capability to All Americans in a Reasonable and Timely Fashion, 14 F.C.C.R. 2398, app. I 13 (1999).

136. Roland Mach. Co. v. Dresser Indus., 749 F.2d 380, 395 (7th Cir. 1984) (citing Product Liab. Ins. Agency v. Crum \& Forster Ins. Cos., 682 F.2d 660, 663-65 (7th Cir. 1982) (Posner, J.)). 
competitors, and a consumer has no interest in the preservation of a fixed number of competitors greater than the number required to assure his being able to buy at the competitive price. Maybe the older, competitor-protection view would survive in a case of naked aggression resulting in the total exclusion of a competitor from the market, but that would be a per se case (if anything) and this is not. $^{137}$

Similarly, Justice (then Judge) Breyer wrote for the First Circuit in 1987: " 'Anticompetitive' [in antitrust law] has a special meaning: it refers not to actions that merely injure individual competitors, but rather to actions that harm the competitive process, a process that aims to bring consumers the benefits of lower prices, better products, and more efficient production methods." 138

The Supreme Court has repeatedly embraced such reasoning. In 1993, for example, the Court stated in Spectrum Sports v. McQuillan: ${ }^{139}$

The purpose of the [Sherman] Act is not to protect businesses from the working of the market; it is to protect the public from the failure of the market. The law directs itself not against conduct which is competitive, even severely so, but against conduct which unfairly tends to destroy competition itself. It does so not out of solicitude for private concerns but out of concern for the public interest. ${ }^{1+0}$

This principle in antitrust law follows from the Court's 1977 decision in Brunswick Corp. v. Pueblo Bowl-O-Mat, ${ }^{141}$ which held that antitrust injury is "injury of the type the antitrust laws were intended to prevent and that flows from that which makes defendants' acts unlawful." 1 2

137. Marrese v. American Academy of Orthopaedic Surgeons, 706 F.2d 1488, 1497 (7th Cir. 1983) (citing University Life Ins. Co. of America v. Unimare Lid., 699 F.2d 846, 853 (7th Cir. 1983) (Posner, J.); Products Liab., 682 F.2d at 663-64). In Products Liabilify. Chief Judge Posner wrote: "The consumer does not care how many sellers of a particular good or service there are; he cares only that there be enough to assure him a competitive price and quality." Products Liab., 682 F.2d at 664 . In another antitrust decision the following year, he wrote that "competition in the antitrust sense signifies not the preservation of all existing competitors but the maintenance of a sufficient number to assure that consumers get the best possible quality of product at the lowest possible price." University Life, 699 F.2d at 852 (citing Products Liab., 682 F.2d at 663-64).

138. Interface Group v. Massachusetts Port Auth., 816 F.2d 9. 10 (1st Cir. 1987) (citation omitted).

139. 506 U.S. 447 (1993).

140. Id. at 458 (citations omitted).

141. 429 U.S. 477 (1977).

142. Id at 489 (emphasis omitted). For similar statements of the Court following. or foreshadowing, the Brunswick articulation of "antitrust injury," see Atlantic Richfield Co. v. USA Petroleum Co., 495 U.S. 328, 338-39 (1990); Cargill, Inc. v. Monfort of Colo.. 479 U.S. 104, 116-17 (1986); Associated Gen. Contractors v. California State Council of Carpenters, 459 U.S. 519, 539-40 (1983); Blue Shield v. McCready, 457 U.S. 465.483 n.19 (1982); J. Truett Payne Co. v. Chrysler Motors Corp., 451 U.S. 557, 562 (1981); and Brown Shoe Co. v. United States, 370 U.S. 294, 320 (1962). 


\section{B. The FCC's Failure To Advance Consumer Welfare}

In its Local Competition First Report and Order, which it issued in 1996, the Commission determined that a "requesting carrier's ability to offer service is 'impaired' ('diminished in value') if 'the quality of the service the entrant can offer absent access to the requested element, declines' or if 'the cost of providing the service rises." ${ }^{143}$ That impairment standard, much like the rest of the FCC's approach to network unbundling, reflects a competitor-based standard, not a competition-based standard.

Unfortunately, the Commission continued in 1999 to consider the economic interests of a given CLEC rather than the effect of the "necessary" and "impair" standards on overall competition. ${ }^{144}$ Indeed, the FCC asked in its Second Further Notice of Proposed Rulemaking whether the "requesting carrier's particular market entry strategies should be considered as part of the 'necessary' and 'impair' analysis." ${ }^{145}$ Moreover, the Second Further Notice of Proposed Rulemaking took liberties in characterizing the relevant statutory language. The FCC stated: "Section 251(d)(2)(B) requires us to consider whether the failure to provide access to an element would 'impair' the ability of a new entrant to provide a service it seeks to offer." ${ }^{146}$ In fact, the statute speaks of a "telecommunications carrier," ${ }^{147}$ and it is inaccurate to characterize CLECs such as AT\&T, MCI WorldCom, and Sprint as "new entrants" in local telecommunications markets. The Commission has yet to consider the crucial difference between the effect on competition, which the Telecommunications Act of 1996 was intended to create, and the economic interests of a particular competitor, which the 1996 legislation did not attempt, and the Commission should not attempt, to protect.

The Second Further Notice of Proposed Rulemaking continued, incorrectly, to impart to the Telecommunications Act of 1996 the "older, competitor-protection view" 148 -even when the FCC's statutory interpretation of $\S 251(\mathrm{~d})(2)$ is judged by standards of antitrust jurisprudence dating at least to the early 1980s. To extend Chief Judge Posner's reasoning from 1983 to the present case, the relevant analysis is whether "either the exclusion of an individual [CLEC] from a local market or the possible effect of that exclusion on the competitive behavior of other

143. Second Further Notice of Proposed Rulemaking, supra note 3, 6 (quoting First Report and Order, Implementation of the Local Competition Provisions in the Telecommunications Act of 1996, 11 F.C.C.R. 15,499, Th 282, 285 (1996)) (emphasis added).

144. See id. II 20.

145. Id. \ 27.

146. Id. II 17 (emphasis added).

147. 47 U.S.C.A. \& 251 (d)(2)(B) (West Supp. 1999).

148. Marrese v. American Academy of Orthopaedic Surgeons, 706 F.2d 1488, 1497 (7th Cir. 1983). 
aspirants ... could result in a higher price or lower quality of [service] in [the affected] communities." 149 The FCC's Second Further Notice of Proposed Rulemaking, however, does not propose to undertake such analysis. Rather, it ascribes paramount importance to the supplications of individual competitors. Thus, as Chief Judge Posner put it, "there is a question to what extent, with their emphasis on the welfare of competitors rather than consumers," those regulators at the FCC proposing a statutory interpretation of $\S 251$ (d)(2) "can survive the consumer-oriented view of antitrust that prevails today." 150 That the business plan of any one CLEC might not be viable unless the FCC were to order the ILEC to unbundle its network elements at TELRIC prices "would have no appreciable effect on competition, viewed as a state in which consumer interests are well served rather than as a process of rivalry that is diminished by the elimination of even one tiny rival." ${ }^{151}$ As Chief Judge Posner concluded thirteen years before the passage of the Telecommunications Act, "That 'there's a special providence in the fall of a sparrow,' is not the contemporary philosophy of antitrust." 152

The economic welfare of any single CLEC will not affect consumer welfare, because consumer welfare depends on the overall competitive supply of telecommunications services. If, under the Commission's interpretation of the "necessary" and "impair" standards, any single CLEC can claim that a given element is necessary to its business strategy, then it is likely that all elements of the network will be subjected to mandatory unbundling at TELRIC prices. Such a standard would harm consumers and diminish consumer welfare. As noted earlier, Justice Breyer discussed this outcome: "Regulatory rules that go too far, expanding the definition of what must be shared beyond that which is essential to that which merely proves advantageous to a single competitor, risk costs that in terms of the Act's objectives, may make the game not worth the candle." 153

As we will explain in greater detail in Part V, the Commission can determine whether competition will be impaired by analyzing whether prices for telecommunications services will be higher or quality (innovation) will be lower as a result of the agency's "necessary" and "impair" policy. Thus, individual competitors' profits are not relevant to a competition standard or a public interest standard.

The Supreme Court realized in Iowa Utilities Board that, in a world of imperfect competition, cost differences that do not arise in marginal cost

149. Id.

150. Id. at $1495-96$.

151. University Life Ins. Co. of Am. v. Unimarc Lid., 699 F.2d 846. 853 (7th Cir. 1983).

152. Id. (quoting WILLIAM SHAKESPEARE. HAMLET, act 5, sc. 2).

153. AT\&T v. Iowa Utils. Bd., 119 S. Ct. 721,754 (1999) (Breyer, J., concurring in part and dissenting in part). 
might have no effect on either competition or competitive prices. The Court stated that "in a world of perfect competition, in which all carriers are providing their service at marginal cost, the Commission's total equation of increased cost (or decreased quality) with 'necessity' and 'impairment' might be reasonable; but it has not established the existence of such an ideal world." 154

There can be no claim that telecommunications is a world of perfect competition given the significant fixed costs and common costs that exist. ${ }^{155}$ Indeed, the Commission's standard for pricing unbundled elements, which includes the fixed costs and foresees the inclusion of a "reasonable share" of forward-looking common costs, specifically rules out the possibility that the Commission believes that perfect competition could occur in the local telecommunications network. ${ }^{156}$

Economists generally accept that with imperfect competition, prices are set as a markup over marginal costs, subject to a breakeven constraint so that the firm can cover its fixed and common costs. ${ }^{157}$ Under free entry, a sufficient number of firms enter so that firms expect to earn their normal cost of capital (that is, they break even). But firms do not earn excess economic profits, because new entry decreases profits to normal levels. Prices exceed marginal costs, but only by enough to cover the fixed and common costs and to allow the firm to earn a normal economic return on invested capital. Thus, an imperfectly competitive outcome could lead to the same (or even lower) prices where CLECs do not have access to a given unbundled element from the ILEC, but instead self-supply the element or buy it from another supplier. The expected profit of a CLEC might be higher if the Commission required the ILEC to supply the unbundled element. Competition, however, could be greater without the requirement because the marginal cost to the CLEC and resulting prices to consumers could well be lower, especially in a scenario of lumpy investment or excess capacity. Thus, under imperfect competition, the "necessary" and "impair" standards do not imply that competition is greatest or consumer welfare is highest when CLEC profits are the greatest, as the Commission has incorrectly assumed. Indeed, the normal result in economics is that a CLEC's profits (which include fixed costs and common costs as factors) bear no necessary relationship to the amount of competition or consumer welfare under an imperfectly competitive outcome.

154. Id. at 735 .

155. See, e.g., BAUMOL \& SIDAK, supra note 11 , at $7,9,34$.

156. See First Report and Order, Implementation of the Local Competition Provisions in the Telecommunications Act of 1996, 11 F.C.C.R. 15,499, I 682 (1996).

157. See SIDAK \& SPULBER, supra note 4, at 359. 


\section{The Ability of ILECs To Negotiate Privately with CLECs}

A decision by the Commission not to impose mandatory unbundling of a particular network element at TELRIC rates would not imply that that network element would be generally unavailable to competitive carriers. The pricing of access and the "necessary" and "impair" standards governing which elements to unbundle are inseparable, as one of us wrote in 1997: "[T]he pricing of network access is inextricably linked to the scope of mandatory unbundling. One cannot say whether or not a particular unbundling obligation is just and reasonable unless one knows how the regulator will permit the incumbent firm to price the mandatory network access associated with that obligation." 158 The Commission's Second Further Notice of Proposed Rulemaking confirms that assessment. Nothing prevents voluntary negotiations between incumbents and competitors on the terms of unbundling. ${ }^{159}$ In short, the issue is not whether the ILECs will unbundle their network elements for use by CLECs, but whether the government will compel the ILECs to do so at TELRIC prices.

In fact, ILECs have a strong incentive to sell unbundled elements to competitors at market-determined prices. Increased usage by the CLEC's customers, and innovative services developed by the CLEC itself, represent a positive externality (or "network effect") that will be enjoyed by the ILEC and all its customers on the network. Furthermore, the RBOCs remain obligated to unbundle loops, local switching, and local transport at market prices to comply with the competitive checklist that is a prerequisite, under $\S 271$ of the Telecommunications Act, for an RBOC's entry into in-region interLATA services. ${ }^{160}$

\section{Mandatory Unbundling Distorts Incentives}

Mandatory unbundling is nothing more than a form of compulsory sharing. In the telecommunications industry, mandatory unbundling can impose social costs by distorting the incentives of both incumbents and entrants.

158. Id. at 565; see also J. Gregory Sidak \& Daniel F. Spulber, Givings, Takings, and the Fallacy of Forward-Looking Costs, 72 N.Y.U. L. REV. 1068, 1163 (1997) (criticizing the FCC's use of TELRIC pricing).

159. The recent consolidations in the CLEC industry (for example, the merger of $\mathrm{MCl}$ and WorldCom) would serve as a countervailing source of market power in any voluntary negotiation. For a review of the recent mergers in the CLEC industry, see Sterling Perrin. The CLEC Market: Prospects, Problems, and Opportunities, Telecommunications INT'L Nov. I. 1998, at 41.

160. See 47 U.S.C.A. $\$ 271$ (c)(2)(B) (West Supp. 1999). 


\section{Incentives of Incumbents}

Disincentive effects on incumbents are substantial, particularly because those firms must continue to make large investments in their existing networks. As noted in Part III, Justice Breyer explained in Iowa Utilities Board the importance of such incentives: "Nor can one guarantee that firms will undertake the investment necessary to produce complex technological innovations knowing that any competitive advantage deriving from those innovations will be dissipated by the sharing requirement." ${ }^{161}$ Regulatory use of cost-based rates (such as TELRIC) creates disincentives for new investment and for innovation in telecommunications. ${ }^{162}$ If the new investment succeeds, the CLEC can purchase the ILEC's unbundled element at cost, as set by TELRIC. If the new investment fails, the CLEC does not bear any of the cost, but the ILEC's shareholders bear the cost of the unsuccessful investment. Thus, the regulators force the incumbent to provide CLECs a free option on its investment. ${ }^{163}$ Modern economic and finance theory demonstrates the value of options, including call options, which are options to buy an asset. ${ }^{164}$ By the principle of "conservation of value" in finance, the Commission's grant of a free option to a CLEC diminishes the expected return of an ILEC's investment by the value of the option given to the CLEC. ${ }^{165}$ Thus, the grant of the option decreases ILECs' incentives to invest. Regulatory reliance on TELRIC pricing causes these free options to be given to competitors at the expense of the incumbent. Even if such an option is never exercised, it nonetheless represents for the CLEC a thing of considerable value, procured for the CLEC's advantage by the government through involuntary exchange. The result is a level of investment and innovation by the ILEC that falls below the economically efficient level. New services will then be provided at less-than-economically-efficient levels, and consumers and businesses will be made worse off. ${ }^{166}$ Thus, the "necessary" and "impair" standards should

161. AT\&T Corp. v. Iowa Utils. Bd., 119 S. Ct. 721, 751 (1999) (Breyer, J., concurring in part and dissenting in part).

162. See SIDAK \& SPULBER, supra note 4, at 403-26, 545-51. For a discussion of the important gains that have been realized by innovation in the Internet, see Jerry A. Hausman, Telecommunications: Building the Infrastructure for Value Creation, in SENSE AND RESPOND 63 (Stephen P. Bradley \& Richard L. Nolan eds., 1998).

163. See AVINASH K. DIXIT \& ROBERT S. PINDYCK, INVESTMENT UNDER UNCERTAINTY (1994); Fisher Black \& Myron Scholes, The Pricing of Options and Corporate Liabilities, $81 \mathrm{~J}$. POL. ECON. 637 (1973).

164. See, e.g., WILLIAM F. SHARPE, INVESTMENTS 471 (3d ed. 1985).

165. For a discussion of conservation-of-value principles, see RICHARD A. BREALEY \& STEWART C. MYERS, PRINCIPLES OF CORPORATE FINANCE 400-01 (4th ed. 1991).

166. For a discussion of particular cases in which regulations were estimated to cost U.S. consumers and businesses billions of dollars because of regulatory delay of new services, see generally Hausman, supra note 12 . 
not be applied to new network service elements, lest diminished competition and decreased consumer welfare result.

For example, consider research and development, or investment in new services. Many new telecommunications services do not succeed. ${ }^{167}$ New information gateway services, which were unsuccessfully offered by ILECs, required substantial sunk developmental costs to create the large databases necessary to provide such services. Under the FCC's TELRIC price regulation, if a new service is successful, a competitor can buy the service at its total service long-run incremental cost (TSLRIC). For a successful new service, the ILEC recovers at most its cost. For unsuccessful services, the ILEC recovers nothing and loses its sunk investment. ${ }^{165}$ Thus, the TELRIC regulation is analogous to a rule that would require pharmaceutical companies to sell their successful products to their generic competitors at incremental cost and would allow the pharmaceutical companies to recover their $R \& D$ and production costs on their successful new drugs, but to recover nothing on their unsuccessful attempts.

This truncation of returns, by which a successful new telecommunications service recovers its cost (but no more) and unsuccessful new services recover nothing, decreases economic incentives for regulated telecommunications companies to offer innovative new services. Thus, as we would expect, tighter cost standards lower the incentives to innovate. More importantly, as the returns on the innovation become more uncertain, the expected return and the incentives to innovate also decrease. (At the same time, under standard option theory, the value of the option implicitly granted to the CLEC rises dramatically, for it is driven by the standard deviation of returns on the optioned network element, which rises with uncertainty.) If the cost-based rate of the unbundled elements corresponding to the new service were set exactly at the cost of providing the new service, with no return for $R \& D$ costs and no reward for uncertainty, then regulation would completely eliminate the economic incentive to provide the new service, because the expected return to the ILEC would always be negative. Thus, regulation would lead to decreased introduction of new services, decreased investment, decreased innovation, and decreased consumer welfare. ${ }^{169}$

The FCC itself explicitly recognized the disincentive effect of mandatory unbundling on investment in its 1998 Advanced Services Notice

167. See, e.g., A. Michael Noll, Anatomy of a Failure: Pichurephone Revisited. 16 TELECOMMUNICATIONS POL'Y 307 (1992); A. Michael Noll. Conspicuous (Lack of Consumption, TELE.COM, Feb. 8, 1999, available in 1999 WL 18391710.

168. See Jerry Hausman, Regulation by TSLRIC: Economic Effects on Investment and Innovation, MULTMEDIA UND RECHT, Mar. 1999, at 22, 22; Hausman, supra note 12; set also SIDAK \& SPULBER, supra note 4, at 375.

169. As noted in Par III, Justice Breyer wamed of this perverse outcome. See supra text accompanying notes $113-114$. 
of Proposed Rulemaking. ${ }^{170}$ In addition, in its 1999 Second Further Notice of Proposed Rulemaking on unbundling, the Commission discussed the ability of competition among carriers to develop and deploy new advanced services. ${ }^{171}$ In the same paragraph, the Commission stated, without any apparent awareness of its self-contradiction, that "it is critical that the marketplace for these services be conducive to investment, innovation, and meeting the needs of consumers." 172 The Commission then stated that the unbundled elements must be offered at cost-based rates. ${ }^{173}$ If the Commission makes the "necessary" and "impair" standards responsive to individual competitors and not to competition, it will create economic disincentives for investment, innovation, and meeting the needs of consumers. Consistent with this analysis, the social costs of unbundling owing to the disincentives for incumbents and entrants to invest should be incorporated into the overall welfare analysis that guides any mandatory unbundling standards that the FCC formulates for interpreting $\$ 251$ (d)(2).

\section{Incentives of Entrants}

Consumers also suffer from the effect of unbundling on the incentives of entrants. If there is no existing alternative supply for a network element but much potential supply, then unbundling will reduce the incentives for alternative suppliers to enter the fray. Conversely, forbearing from unbundling will increase the opportunities for entrants, promote facilitiesbased competition, and promote diversity for innovation, choice, and product diversification. To make things worse, unbundling could cause an already present CLEC to exit.

In May 1997, the Canadian Radio-Television and Telecommunications Commission (CRTC) adopted an unbundling policy that is responsive to such concerns when, in contrast to the FCC's Local Competition First Report and Order, the agency ordered that Canadian ILECs "should generally not be required to make available facilities for which there are alternative sources of supply or which [competitive local exchange carriers] can reasonably supply on their own." ${ }^{174}$ Mandatory unbundling in Canada extends only to the ILEC's "essential" facilities. ${ }^{175}$ As the CRTC understood, compulsory unbundling requirements can deprive facilities-

170. See Memorandum Opinion and Order, and Notice of Proposed Rulemaking. Deployment of Wireline Services Offering Advanced Telecommunications Capability, 13 F.C.C.R. 24,012, $19195-100$ (1998).

171. See Second Further Notice of Proposed Rulemaking, supra note 3. 13.

172. Id. This passage is the only reference to investment or innovation in the entire Second Further Notice of Proposed Rulemaking.

173. See id. $\mathbb{1} 4$.

174. Local Competition (1 May 1997), No. 97-8, 174 (C.R.T.C.).

175. See id. 
based entrants of opportunities to share costs, achieve efficient scale, and maximize the utilization of infrastructure that is sunk or comes at zero marginal costs.

\section{E. The Effects of Removing TELRIC Pricing}

Regulated prices that are set on the basis of TELRIC confer implicit subsidies to those who purchase unbundled network elements. ${ }^{176}$ That point has already been made; its negative implications for efficiency, competition, and innovation likewise have been noted. Those highly favorable prices encourage the use of and reliance on unbundled network elements of the incumbent. They also discourage the use of and investment in competitors' own facilities. The availability of those UNEs at inefficiently low prices not only attracts firms that could have deployed their own facilities, but also induces firms that could not have efficiently entered or expanded in the marketplace to do so. The subsidized prices shield inefficient entrants from the true economic prices that they would otherwise be forced to face.

A problem arises if those subsidized prices are subsequently brought up to market-based, efficient levels. Clearly, as markets become increasingly competitive, network elements that are required to become unbundled may not continue to face that requirement at some point in the future. When prices are allowed to rise to efficient levels, whether by market forces or by regulation, those marginal firms may well incur financial difficulties, at least with respect to the purchase of certain UNEs. Any such difficulties should not be considered in determining whether the "impairment" standard has been met. Surely the Telecommunications Act does not intend any such result. If that measure of "impairment" were entertained, it would suggest that unbundling should be used indefinitely to support inefficient producers of telecommunications services. Such an outcome would be contrary to the interests of competition, consumer welfare, and the public interest.

The need to ignore the effects of removing subsidies from unbundled element prices further underscores the need to focus on competition, not competitors. Assuming that every new competitor in the marketplace is not inefficient (a result that would imply the existence of a natural monopoly), there is no need to assess the effect at the individual firm level. It will suffice to concentrate on competition in the market, appropriately defined.

176. See SIDAK \& SPULBER, supra note 4 , at 410-12. 


\section{F. The Importance of Sunk Costs}

The concepts of "necessary" and "impair" cannot usefully be analyzed without recognizing the central role of prices and costs in telecommunications. As we shall explain in greater detail in Part $\mathrm{V}$, within the essential facilities doctrine, costs have a primary role in the sense that an essential facility is something that "cannot be economically duplicated." Thus, as Justice Breyer noted, if the Commission establishes a pricing rule for unbundled elements that is uneconomically low, it can incorrectly make an unbundled element appear to be "necessary" or "essential" for competition, because a CLEC will not be able to self-provide the element at a cost near the Commission's established price. Nor would the CLEC be able to buy use of the element from another provider at a price near the Commission-set price, because of the uneconomically low price that the agency has set. Thus, the "necessary" and "impair" standards cannot be considered as a legal doctrine in isolation from the basic economics and technology underlying the network and the Commission's approach to establishing the price of unbundled elements.

The economic distinction between unbundled elements that require only a fixed-cost investment and those that require a sunk-cost investment plays an important role in both the "necessary" and "impair" standards and the essential facilities standards. ${ }^{177} \mathrm{~A}$ fixed-cost investment may require a significant expenditure of capital, but it does not necessarily result in an element meeting the "necessary" and "impair" standards. Capital markets work well in the United States, so CLECs can always raise the necessary capital for an investment in a fixed-cost element. The essential economic feature of a fixed-cost investment is that if the project does not succeed, the capital equipment can be used in alternative projects. For example, a switch, along with its associated software, is largely a fixed-cost investment. Although the cost of a switch is significant, if the CLEC fails to attract sufficient business to be successful, the CLEC can sell the switch and software. Thus, a switch and the associated software cannot lead to an element satisfying the "necessary" or "impair" requirement of $\$ 251$ (d)(2), because a CLEC would not be at a significant economic disadvantage if it did not have access to the ILEC's switches.

Sunk-cost investments differ from fixed-cost investments because the capital cannot be recovered from a failed sunk-cost investment. Thus, most of the invested capital cannot be shifted to an alternative project. ${ }^{178}$ Residential loops provide an example of sunk-cost investment. Large

177. The FCC requests commentators to provide an analysis of the effect of sunk costs in defining the "necessary" and "impair" standard. See Second Further Notice of Proposed Rulemaking, supra note 3, $\mathbb{} 26$.

178. See SIDAK \& SPULBER, supra note 4 , at 78-82. 
sunk-cost investments can also provide one of the necessary conditions to establish the existence of an essential facility, because it may be uneconomical for the CLEC to attempt to duplicate large sunk-cost investments given the high degree of risk involved. The Second Further Notice of Proposed Rulemaking ignores the relevance of an ILEC's sunk investment in a network element to mandatory unbundling. Paradoxically, the FCC's sole concern over sunk costs is their effect on CLECs-whether sunk costs "would be incurred by requesting carriers if they were to obtain the network elements through self-provisioning or from other sources outside the incumbent LEC's network (e.g., those costs associated with entry that are not fully recoverable if the requesting carrier exits the market)." 179

During the 1996 interconnection proceedings, in response to testimony regarding the role of sunk and irreversible investments in setting economically efficient unbundled element prices, one IXC claimed that many of the ILEC's elements were fixed, but were not sunk-cost investments. ${ }^{180}$ As we discussed above, if an investment in an unbundled element is fixed but not sunk, the element cannot satisfy either the "necessary" or "impair" requirement. A CLEC can always raise the necessary investment funds in the capital markets and begin competing. If the CLEC is unsuccessful, the CLEC can always resell, without a significant economic loss, the capital equipment in which it invested. Only an element necessitating a sunk-cost investment can satisfy the "necessary" and "impair" requirements.

\section{G. The Commission's Artificial Justifications for Mandatory Unbundling}

\section{Conferral of a Valuable Option on the CLEC}

If the Commission requires an ILEC to unbundle, at a TELRIC price, a network element that has a significant sunk cost, the agency is compelling the ILEC to provide an option to the CLECs. ${ }^{181}$ The CLEC can decide to invest in its own facilities or to buy the use of the unbundled element from the ILEC. If the element arises from a sunk and irreversible investment, the option is valuable because the CLEC need not take the risk of investment but instead can cause the ILEC to take that risk. For the example of investment in a residential loop, a significant risk exists that over the next twenty years (or the economic lifetime of a residential loop), wireless competition or cable competition may cause the prices of services offered over residential loops to decrease significantly. Moreover, in twenty years

179. Second Further Notice of Proposed Rulemaking. supra note 3. 926.

180. See First Report and Order, Implementation of the Local Competition Provisions in the Telecommunications Act of 1996, II F.C.C.R. 15.499. 1641 n.1562 (1996).

181. See Hausman, supra note 168, at 24-26; Hausman, supra note 12, at 26-35. 
copper-based residential loops may not even be in widespread use because wireless "loops" may prove to be significantly less costly, or because the broadband feature of cable television networks may cause demand to shift away from copper-based ILEC loops. ${ }^{182}$ If a CLEC buying an unbundled sunk-cost element from an ILEC were required to sign a contract for the economic life of the investment (say, twenty years), then the CLEC would not receive a "free option" from the ILEC.

But the Commission's current pricing policy of using TELRIC for mandatory unbundling neither requires a CLEC to sign a contract for the economic life of the element nor provides the ILEC a markup to pay for the economic value of the option that regulators compel it to issue. Thus, CLECs can tenably argue that access to unbundled elements is necessary for all sunk-cost elements because competitive supply of those elements will not exist. The competitive supply will not arise because the Commission has set an uneconomically low price for the element that does not recognize the sunk-cost nature of the required investments. If ILECs are required to supply unbundled elements at prices below economic costs, they will be elements that (erroneously) satisfy the "necessary" and "impair" requirements of $\S 251(\mathrm{~d})(2)$. Those UNEs will appear to satisfy the statutory test not for correct economic reasons, but because the Commission will have cut off any prospect of facilities-based competition through its pricing policies.

\section{Distorting the Price Elasticity of Derived Demand}

Regulators distort the apparent need for mandatory unbundling when they force an ILEC to lease a network element at TELRIC rather than at a price that incorporates the full option value conferred on the CLEC. Any UNE priced below its full option value will exhibit artificially higher demand than would obtain at a price that incorporated that option value. If the demand curve for the element is linear, then demand will be observed at the more price-inelastic portion of the demand curve. Thus, asking whether competitors would substitute away from consumption of the element if the ILEC attempted to impose a nontransitory price increase of nontrivial magnitude would automatically lead to a misdiagnosis of market power, for the elasticity calculation would be made with respect to a starting point that is, by regulatory distortion, too far down the demand curve. ${ }^{183}$

182. Of course, digital subscriber line (DSL) technology may allow for broadband to be offered over ILEC loops. The point is that the technological evolution of competition is sufficiently uncertain to make investment in sunk-cost elements equally uncertain.

183. A technical caveat is necessary here. In the case of an isoelastic demand curve, such as one associated with a Cobb-Douglas utility function, the price elasticity of demand is constant at all points along the (nonlinear) demand curve. Cf. JAMES M. HENDERSON \& RICHARD E. Quandt, Microeconomic Theory: A MATHEMATICAL APPROACh 111-13 (3d ed. 1980) 
Antitrust lawyers and economists will recognize this analytical refinement to be the converse of the error in the Cellophane case, where the cross-price elasticity of demand was evaluated at the putatively higher monopoly price. ${ }^{185}$ In Cellophane, that error falsely overstated the product's cross-price elasticity of demand at the competitive price. ${ }^{185}$ In the case of the FCC's mandatory unbundling of network elements at TELRIC prices, a "reverse Cellophane" problem arises: The FCC's failure to evaluate the price elasticity of demand for that element at a price that would cover the element's full option value would falsely understate the element's price elasticity of demand-and hence the true measure of its degree of "impairment" for purposes of $\S 251$ (d)(2)at a competitive price. Simply put, an element that is unnecessary for the competitive supply of telecommunications services can be erroneously made to appear to satisfy the "impairment" standard for purposes of $\S 251$ (d)(2) as long as the ILEC is obliged to sell the unbundled element at a noncompensatory price, and the FCC declines to correct for that market distortion.

A related implication of that insight is that the FCC can perpetuate the apparent need for its regulatory intervention by predicating its mandatory unbundling rules on determinations of "impairment" that assume that UNE prices are set at TELRIC levels. The regulator's stimulation of excess demand for UNEs thus preordains the result that the network element in question must be subject to mandatory unbundling. The FCC has used that regulatory strategy for years in another context: the regulation of broadcasting. The justification for regulatory intervention into the market structure and conduct of broadcasters was the putative "scarcity" of spectrum, which the FCC itself controlled through its licensing policies. The FCC artificially created excess demand for spectrum by underpricing it (at a zero price) and then justified its intervention as a way to alleviate the consequences of that excess demand. Judge Stephen Williams has referred to this putative spectrum "scarcity" as "an excess of demand over supply at a price of zero." 186 In the same

(discussing constant elasticity of substitution of the Cobb-Douglas production function). Even in such a case of an isoelastic demand curve, however, it is still tue that the FCC, by setting 100 low a price for the UNE, would suppress competitive supply of that element. As will become clear from our discussion infra Part $\mathrm{V}$, such a regulatory distortion would make it more difficult for the ILEC to meet the "critical share" calculation, which would establish that the ILEC could not impair competition in the market for telecommunications services sold to end-users by declining to lease a particular network element to a CLEC at a TELRIC price.

184. See United States v. E.I. du Pont de Nemours \& Co.. 351 U.S. 377,404 (1956).

185. In the Cellophane case, the government claimed that du Pont was exercising unilateral monopoly power over food wrappings. By allegedly increasing the price of Cellophane to monopoly levels, du Pont caused competitors to supply, and consumers to buy, other wrapping materials. The government claimed that such supply and demand substitution did not prove that Cellophane would exhibit significant cross-price elasticity at a comperitive price. See RICHARD A. POSNER, ANTITRUST LAW: AN ECONOMIC PERSPECTIVE 127-28 (1976).

186. Time Warner Entertainment Co. v. FCC. 105 F.3d 723, 724 n.2 (D.C. Cir. 1997) (Williams, J., dissenting from the denial of rehearing in banc). 
manner, the pricing of UNEs according to the FCC's Local Competition First Report and Order would exaggerate the demand for, and hence the evident "necessity" of, the FCC's order of mandatory competitor access to those UNEs at regulated prices.

\section{The Commission's Endogenous Determination of the Substitutability of Wireline Access for Wireline Loops}

Because the Commission controls the amount of spectrum that is allocated to commercial uses, the agency also controls the availability of alternative supply of telecommunications services. The amount of spectrum potentially available to wireless competitors could increase substantially beyond the current $180 \mathrm{MHz}$ allocated to cellular, personal communications services (PCS), and enhanced specialized mobile radio (ESMR) spectrum. Numerous blocks of spectrum are currently scheduled to be auctioned. ${ }^{187}$ As with its underpricing of UNEs, the pace at which the Commission issues new spectrum licenses may exaggerate the apparent justification for the mandatory unbundling of wireline networks. This regulatory distortion is significant because, as we discuss below, ${ }^{188}$ the availability of substitute offerings at the end-user level, such as wireless local loops, constrains the ability of the ILEC to exercise market power and hence protects consumer welfare.

\section{LIMITING PRINCIPLES DERIVED FROM MODERN ANTITRUST JURISPRUDENCE}

Our definitions of "necessary" and "impair" rely on the competitive analysis of demand and supply substitution that provides the primary basis for other areas of regulatory economics and, more particularly, that provides the analytical basis for modern antitrust jurisprudence. In this Part, we first review the logic and limits of the essential facilities doctrine and examine its empirical implications with respect to defining relevant markets in both geographic and temporal dimensions. ${ }^{189} \mathrm{Next}$, we apply that understanding of antitrust analysis to define our test of "impairment." We then extend our analysis to define "necessary" for purposes of $\S 251$ (d)(2). Finally, we discuss how related policies of the Commission may distort the conclusions derived

187. For summaries of pending FCC spectrum auctions, see <http://www.fcc.gov/wtb/ auctions > (visited Nov. 22, 1999).

188. See infra text accompanying notes 197, 218-221.

189. The following discussion directly responds to the FCC's request for "comment on the significance of the essential facilities standard under section 251(d)(2)." Second Further Notice of Proposed Rulemaking, supra note 3, I 21 ; see also id. 19 22-23. Of necessity, our discussion here treats in summary fashion a topic that merits lengthier analysis. For a thorough and up-to-date examination, see generally Lipsky \& Sidak, supra note 4. 
from any application of the essential facilities doctrine or market power analysis to mandatory unbundling.

\section{A. The Logic and Limits of the Essential Facilities Doctrine}

The essential facilities doctrine addresses scenarios in which a company owns a resource that other firms absolutely need to provide their own services. Properly understood, the doctrine is a common-law rule concerning the obligation (if any) of a vertically integrated firm to sell an input to competitors in the downstream market. Federal courts first applied the essential facilities doctrine to telecommunications networks in $\mathrm{MCl}$ Communications Corp. v. American Telephone \& Telegraph Co. ${ }^{190}$ In that case, the Seventh Circuit refined the essential facilities doctrines into a four-part test that requires the plaintiff to show "(1) control of the essential facility by a monopolist; (2) a competitor's inability practically or reasonably to duplicate the essential facility; (3) the denial of the use of the facility to a competitor; and (4) the feasibility of providing the facility." 191 Inherent in the concept of an "essential facility" is the premise that the owner of that facility possesses monopoly power. The first two elements of the doctrine incorporate that recognition in a variety of ways. First, some degree of uniqueness and market control is inherent in the term "essential." Second, the inquiry regarding the impracticability of duplication ensures that the doctrine will apply only to facilities for which no feasible alternative exists or that cannot be reasonably reproduced. Finally, the term "facility" itself connotes an integrated physical structure or large capital asset with the degree of cost advantage or unique character that usually confers monopoly power and market control by virtue of its superiority.

Although, as noted by Justice Breyer in Iowa Utilities Board, the Supreme Court has never endorsed the essential facilities doctrine, ${ }^{192}$ seven Justices nonetheless agreed in that case that the doctrine might be useful, by analogy, as a limiting principle in interpreting the "necessary" and "impair" standards of $\S 251$ (d)(2) of the Telecommunications Act. ${ }^{193} \mathrm{~A}$ strength of the doctrine is that it has shown the capacity to screen out a multitude of unmeritorious claims. ${ }^{194}$ In that respect, the doctrine plainly rejects the notion, embodied in the Local Competition First Report and Order, that the public interest is advanced by the simplistic rule that any compulsory sharing that is technically feasible should be required. Indeed,

190. 708 F.2d 1081 (7th Cir. 1983).

191. Id. at 1132-33.

192. See AT\&T Corp. v. Iowa Utils. Bd., 119 S. Ct. 721,753 (1999) (Breyer, J., concurring in part and dissenting in part).

193. See id. at 734-35; id. at 753 (Breyer. J., concurring in part and dissenting in part).

194. See Lipsky \& Sidak, supra note 4. 
as we shall show presently, the technical feasibility of access is a necessary but not sufficient condition for mandatory unbundling to advance consumer welfare.

It is inappropriate to apply the essential facilities doctrine to circumstances in which the owner of the facility lacks monopoly power in the market for the end service employing the input, because without monopoly power there can be no basis for applying antitrust principles and remedies. Justice Breyer seemed to make that point in Iowa Utilities Board:

[A]lthough the provision describing which elements must be unbundled does not explicitly refer to the analogous "essential facilities" doctrine (an antitrust doctrine that this Court has never adopted), the [Telecommunications] Act [of 1996], in my view, does impose related limits upon the FCC's power to compel unbundling. In particular, I believe that, given the Act's basic purpose, it requires a convincing explanation of why facilities should be shared (or "unbundled") where a new entrant could compete effectively without the facility, or where practical alternatives to that facility are available. ${ }^{195}$

If the facility must compete for users with other products or services that are effective substitutes for access to the facility, the discipline imposed by such competition will suffice to control the conduct of the facility owner.

There will, of course, be instances in which the facility in question will be somewhat better than the alternatives, but not so much better as to preclude the continued survival of excluded parties. The colorful exchange between Justices Scalia and Souter about ladders and lightbulbs ${ }^{196}$ confirmed that the Court in Iowa Utilities Board understood this concern in the context of mandatory unbundling of network elements under the Telecommunications Act. It may be difficult indeed to determine whether exclusion from the use of a particular facility will mean inconvenience, extinction, or some intermediate degree of harm to the excluded competitor. The point is not that the judgment as to the magnitude of the competitive disadvantage of exclusion is simpler in principle with one test instead of another. Rather, the point is that the question of "essentiality" and ease of duplication-measured by either the potential harm of exclusion or the potential benefit of inclusion-is no different from, and ought legally to be the same as, the issue of whether monopoly power is present in the market for the service produced with the allegedly "essential" facility. The focus of courts and regulators should be on whether mandatory access to the

195. Iowa Utils. Bd., 119 S. Ct. at 753 (Breyer, J., concurring in part and dissenting in part).

196. See id. at $735 \mathrm{n} .11$; id. at 739 (Souter, J., concurring in part and dissenting in part); supra text accompanying note 76. 
facility will enhance the long-term welfare of consumers, regardless of the effect on individual competitors.

Because a finding of monopoly power should be a prerequisite to any further inquiry, any market characteristic that prevents the exercise of market power should preclude the application of the essential facilities doctrine. Suppose, for example, that a pipeline is the only means of transporting oil from the field where it is produced to the city where it is consumed. Suppose further that some local topographical feature precludes construction of an alternative pipeline. At first, it might appear that the refusal of the pipeline owner to permit competing oil distributors to ship their oil through the pipeline is an act of monopolization by virtue of the essential facilities doctrine. If oil is readily available to the region from another source, however, no monopoly constraint on pipeline output (or enhancement in price) would be rational or, in equilibrium, even possible. Alternatively, there may be an energy source that is a reasonable alternative for consumers of oil. In either case, the consequence would be that no method of transporting oil-regardless of the "facility" by which transport is supplied-could exercise monopoly power. The demand for use of the facility is a derived demand based on the underlying demand for the end product-in this case, consumers' use of energy ${ }^{197}$ The derived demand for the facility cannot confer greater market power on its owner than exists for the end product for which that facility would be an input. Under those circumstances, there is no reason to apply antitrust enforcement mechanisms, because no change in the conduct of the facility owner would increase consumer welfare or improve resource allocation.

Facilities with otherwise identical characteristics may have different antitrust obligations, depending on the availability of substitutes for the output of the facility. The only shopping mall in a geographically isolated locality may have antitrust obligations that are not shared by an identical facility in the suburbs of a metropolis. Equally significant, the same facility may have different antitrust obligations depending on the time of the suit. The first shopping mall in a newly developed area may be found to have monopoly power - that is, the facility may be regarded as "essential" - and exclusion of competing retailers may well create liabilities under $\S 2$ of the Sherman Act. The identical shopping mall, however, may lose such

197. See Illinois ex rel. Hartigan v. Panhandle E. Pipe Line Co.. 730 F. Supp. 826, 866 (C.D. Ill. 1990) (defining the concept of "derived demand"); United States v. Standari Oil Co.. 155 F. Supp. 121, 146 (S.D.N.Y. 1957) ("The demand for ocean tankers is a derived demand reflecting changes in the demand for petroleum and its products. An increase in the demand for crude and its products would ordinarily bring an increased demand for ocean tankers and an increase in ocean tanker rates."). The former Interstate Commerce Commission employed such an analysis of demand and supply substitution in the 1980 s when reforming rate-regulation principles for rail transportation supplied to "captive shippers." See Burlington N.R.R. v. ICC. 985 F.2d 589. 59599 (D.C. Cir. 1993). 
antitrust obligations once competing commercial real-estate developments have emerged in the natural growth and development of commercial real-estate capacity. In short, the essential facilities doctrine should be temporally bounded, although courts have failed to recognize that requirement.

The foregoing analysis suggests why, in the vast majority of essential facilities doctrine cases, the federal courts have declined to find the facility in question "essential." ${ }^{198}$ That pattern has prompted academic criticism of the essential facilities doctrine, including criticism by one of the present authors. ${ }^{199}$ The criticisms of the essential facilities doctrine may reflect two underlying forces, one which is irrelevant to the FCC's interpretation of $\S 251(\mathrm{~d})(2)$ and the other which underscores the need for a limiting principle.

First, remedies in essential facilities cases necessarily require some form of regulation. In other words, by hypothesis no remedy of mandated access can eliminate the underlying monopoly. Once identified, the role of judicial regulation (through injunction or consent decree) in essential facilities cases may be judged by the same standards applied to other forms of public control of natural monopolies. The central thesis derived from this analysis is that the wisdom of judicial regulation of essential facilities requires an assessment of the administrative complexity of the relief proposed. But this consideration is not applicable to a regulatory agency like the FCC, which already has the expertise and resources to administer a regime of mandatory access, if one is deemed necessary.

The second criticism directed against the essential facilities doctrine concerns the incentives created by the doctrine and their dynamic effect on consumer welfare. As Justice Breyer noted in lowa Utilities Board, compulsory sharing of property has social costs because it truncates the returns to private investment, especially investment in innovative activity. There are obvious social costs when competitors, like children in al sandbox, are admonished to share. Any case in which the fundamental output of the facility consists of information or any other form of intellectual property seems a poor candidate for application of the essential facilities doctrine. The essential facilities doctrine is, above all, a legal rule

198. Those decisions are surveyed in Lipsky \& Sidak, supra note 4, at 1191-93.

199. See Phillip E. Areeda, Essential Facilities: An Epithet in Need of Limiting Princuples, 58 ANTITRUST L.J. 841 (1989) (arguing that no Supreme Court case has provided a consistent rationale for the doctrine or has explored either the social costs and benefits or the administrative costs of requiring the creator of an asset to share it with a rival): Donald I. Baker. Compulsory Access to Network Joint Ventures Under the Sherman Act: Rules or Roulette?. 1993 UTAH L. REV. 999 (arguing that the core conceptual problem with compulsory access orders is that mandating cooperation among businesses is futile); Lipsky \& Sidak, supra note 4. at 1191-93.

200. See Iowa Utils. Bd., 119 S. Ct. at 753-54 (Breyer, J., concurring in part and dissenting in part). 
of mandatory sharing and compulsory dealings. That characteristic alone is inconsistent with the exclusivity granted to innovators, which the government has decided is appropriate to preserve their incentives to create new properties. The essential facilities doctrine, moreover, is most likely to condemn intellectual property in precisely those circumstances in which that result is least defensible: Under the essential facilities doctrine, the more an invention is unique, valuable, and difficult to duplicate, the greater the obligation to share it. In short, essential facilities principles are inherently inconsistent with intellectual property protection.

This consideration regarding intellectual property has direct relevance to the FCC's interpretation of the "necessary" and "impair" requirements. The Telecommunications Act contains this solicitude for intellectual property, for . $\$ 251(\mathrm{~d})(2)$ does not mandate the unbundling of a "proprietary" network element unless it satisfies both the "impair" standard and the "necessary" standard. ${ }^{201}$ Furthermore, those two factors are what the Commission must consider "at a minimum" when deciding whether to mandate unbundling. ${ }^{202}$ The FCC's consideration of additional factors in appropriate cases should tighten rather than expand the focus of this authority to mandate unbundling in the public interest.

\section{B. Deriving the "Necessary" and "Impair" Standards from the Essential Facilities Doctrine}

\section{Temporal and Geographic Specificity}

The FCC should interpret "necessary" and "impair" with temporal and geographic specificity. The FCC can usefully identify multiple geographic zones for unbundling purposes without imposing a uniform nationwide unbundling rule-let alone a uniform nationwide presumption or outcome. ${ }^{203}$ Without temporal and geographic specificity in its mandatory unbundling rules, the FCC would create a body of law in direct conflict with the antitust principles that the Court considered relevant to interpreting $\$ 251$ (d)(2). The resulting vision of competition would at best bear no relation to a rigorous economic understanding of the terms "necessary" or "impair" and at worst be affirmatively harmful to consumers.

The Second Further Notice of Proposed Rulemaking, however, incorrectly concluded that establishment of minimum national unbundling

201. For proprietary network elements, the statutory requirement is conjunctive: "necessary ... and .. impair." 47 U.S.C.A. \$ 251(d)(2) (West Supp. 1999) (emphasis added). 202. Id.

203. Cf. Second Further Notice of Proposed Rulemaking, supra note 3 (separate statement of Commissioner Powell) ("I disagree shaply ... that we should designate the same elements of the incumbent's network for unbundling of every region of the nation."). 
requirements remains valid under the Court's decision in Iowa Utilities Board. ${ }^{204}$ The FCC could "find nothing in the Supreme Court's decision that calls into question our decision to establish minimum national unbundling requirements." ${ }^{205}$ That statement is remarkable because Justice Scalia's reference to supply substitution for the ILEC's network elements presupposes a competitive analysis that must 'begin by defining relevant product and geographic markets. The references by Justices Scalia and Breyer to the essential facilities doctrine reinforce the premise that competition must be evaluated with respect to a meaningful geographic market. The FCC's tentative conclusion about the need to impose nationwide unbundling requirements is inconsistent with the holding in Iowa Utilities Board because that conclusion is inconsistent with the underlying technology used to provide local telephone service and with the analysis in a number of previous Commission decisions. ${ }^{206}$ Consider residential telephone service: The basic technology to provide circuitswitched local telephone service to residential customers is essentially the same throughout the United States. ${ }^{207}$ But, as discussed in many prior Commission decisions and recognized throughout U.S. telecommunications policy, costs differ greatly among different geographical areas. Since the technology being employed is essentially the same, it follows that features of the geographical areas lead to the large variation in costs. ${ }^{208}$ Indeed, the FCC discusses economies of scale and economies of density that yield those differences in costs. ${ }^{209}$ Those differences in costs would be expected to lead to differences in competition. ${ }^{210}$

When the density of customers is high enough and the number of customers is large enough in a given geographical area, the economies of scale and density will either be exhausted or will become sufficiently small so as not to have an economic effect of any significant magnitude. In that situation, an ILEC will not have an economic advantage, and economic analysis leads to the prediction of significant CLEC entry. Indeed, Commissioner Michael Powell of the FCC correctly recognized the principle that, when competitors already exist in a particular market, other

204. See id. 114.

205. Id.

206. See, e.g., Memorandum Opinion and Order, Applications of NYNEX Corp.. Transferor. and Bell Atlantic Corp., Transferee, for Consent to Transfer Control of NYNEX Corp. and its Subsidiaries, 12 F.C.C.R. 19,985, II 49-57 (1997).

207. See, e.g., J. Gregory Sidak \& Daniel F. Spulber, Cyberjam: The Law and Economics of Internet Congestion of the Telephone Network, 21 HARV. J.L. \& PUB. POL'Y 327, 336 (1998).

208. See, e.g., ROBERT W. CRANDall \& LEONARD WAVERMAN, TAlK IS CHEAP: Tui: PROMISE OF REGULATORY REFORM IN NORTH AMERICA 80-85 (1995).

209. See Second Further Notice of Proposed Rulemaking. supra note 3. 726.

210. Indeed, the definition and geographical scope of the LATAs took account of customer density and its expected effect on long-distance competition. See KELLOGG ET AL., stipra note 19. at 227-34. 
firms would not be impaired in their ability to compete if they do not have unbundled access to the ILEC's network elements, let alone unbundled access at TELRIC prices. ${ }^{21}$ Furthermore, that economic analysis is confirmed by the finding that facilities-based CLECs are much more prevalent in urban, high-density areas than in more rural areas. ${ }^{212}$

The employment of a single nationwide standard would directly contradict the market-definition standards found in the Department of Justice and Federal Trade Commission's Merger Guidelines, ${ }^{213}$ which the FCC has used in its own recent merger reviews under the public interest standard of the Communications Act. ${ }^{214}$ In terms of geographic market definition, the Merger Guidelines ask whether a hypothetical (unregulated) monopolist could impose a "'small but significant and nontransitory" increase in price." ${ }^{215}$ That standard is established by determining whether the hypothetical monopolist would have market power or, alternatively, would be constrained by firms outside the market. ${ }^{216}$

In a given geographic market, the correct question is whether an (unregulated) ILEC could exercise market power if it were not required to provide its competitors a given unbundled element at regulated, cost-based rates. If other CLECs are already providing competing services using the element, or if the element itself is available from non-ILEC suppliers, then an ILEC could not exercise market power. Provision of the unbundled element by the ILEC would not be necessary for competition in telecommunications services in the given geographic area. Nor would competition be impaired if the ILEC were not required to supply the unbundled element at cost-based rates. It is likely, however, that the outcome of that analysis would differ depending on the particular element and the geographical area under consideration.

As an example, consider transport. In a densely settled area with a high population, such as eastern Massachusetts around Boston (the eastern Massachusetts LATA), numerous competitors currently provide transport competition to Bell Atlantic. In rural areas of western Massachusetts, however, competitor provision of transport is considerably less developed. Furthermore, Bell Atlantic's costs of providing local service and

211. See Second Further Notice of Proposed Rulemaking. supra note 3 (separate statement of Commissioner Powell).

212. See Industry Analysis Div., FEderal Communications COMm'N, ReportLOCAL COMPETITION 2 (1998).

213. See 1992 Horizontal Merger Guidelines, 57 Fed. Reg. 41 .552, 41.554-58 (1992).

214. See, e.g., Memorandum Opinion and Order. Application of WorldCom. Inc. and $\mathrm{MCl}$ Communications Corporation for Transfer of Control of $\mathrm{MCI}$ Communications Corporation to WorldCom, Inc., 13 F.C.C.R. 18,025, 94 37-39 (1998).

215. 1992 Horizontal Merger Guidelines, 57 Fed. Reg. at 41.556.

216. This approach is similar to that found in economics textbooks, see. e.g. CARLTON \& PERLOFF, supra note 15, at 801-07, and in the legal literature, see, e.g., Landes \& Posner, supra note 14. 
transport vary significantly between eastern Massachusetts and western Massachusetts.

Hypothetically, Bell Atlantic might be able to increase the price of transport in rural areas of western Massachusetts above competitive levels, but it could not do so in eastern Massachusetts. Bell Atlantic's competitors need not provide transport to every location in eastern Massachusetts for transport to be competitive. Because Bell Atlantic is required to offer transport under tariff by using nondiscriminatory prices, Bell Atlantic needs to lose only a relatively small share of its overall transport business in eastern Massachusetts for an attempted price increase to be unprofitable. If competitors offer competitive transport to a sufficient number of locations in eastern Massachusetts, competition will effectively constrain Bell Atlantic's prices. Thus, the added regulatory mandate that Bell Atlantic provide CLECs unbundled transport elements in eastern Massachusetts at TELRIC prices will not affect competition. Transport does not meet that interpretation of the "impair" standard in eastern Massachusetts. As this example illustrates, it will be necessary for regulators to make separate determinations under the "impair" standard for different geographic areas.

It is conceivable that a CLEC would argue that its ability to provide an end service to consumers would be impaired for purposes of $\S 251$ (d)(2) if the ILEC did not simultaneously unbundle a particular element throughout the ILEC's entire service territory. There are two fallacies in such reasoning. First, it presumes that the service territory is identical to the relevant geographic market. That will be a factual question, but in general ILEC service territories spread over far larger expanses than one would typically regard as a single geographic market for purposes of competitive analysis. Second, the argument misconceives how entry occurs and how much entry is necessary to impart competition to a market. Entrants target their customers, and competition takes place at the margin. As our discussion of critical share will demonstrate, ${ }^{217}$ it is the marginal consumers rather than the inframarginal consumers whose choices determine the competitiveness of a market. The argument that competition would be impaired unless a CLEC can simultaneously serve all consumers, marginal and inframarginal alike, overstates the critical share of the ILEC's customers that is necessary for the CLEC to capture to produce a competitive equilibrium.

In summary, whether the FCC should mandate the unbundling of a particular network element in a particular geographic location at a particular time should depend on whether such unbundling is necessary to permit the competitive supply of telecommunications services to end users. The correct meaning of "impair" for purposes of $\S 251$ (d)(2) is whether the ILEC's 
failure to unbundle a particular network element, at a TELRIC price, in a particular geographic location at a particular time would produce an equilibrium supply of telecommunications services that was, relative to the competitive equilibrium, significantly inferior for consumers.

\section{Incorporating Derived Demand}

An olive is necessary for a good martini. But that does not make an olive an essential facility, which Rick should be obliged to offer for sale, at cost, to every other saloon keeper in Casablanca. Although a particular network element may be essential to producing a bundle of services in a particular manner, the existence of competition among bundles of services limits the extent to which that element is essential to the competitive supply of telecommunications services. More specifically, the development of wireless voice, data, and vertical services has served to increase the availability of substitutes for wireline access. This insight about competition at the service level is analogous to the economic concept of derived demand, which has been incorporated into antitrust and regulatory law for many years. In the context of $\S 251$ (d)(2), the relevant question is whether competition among bundles of services produces, for a particular network element, a sufficiently low level of derived demand such that the element is inessential to producing a competitive equilibrium.

In the language of economics, "necessity" and competitive "impairment" are given rigorous economic meaning by computing the price elasticity of derived demand for any given unbundled network element. That exercise is a direct application of insights in microeconomic theory explicated early in the twentieth century by the great British economist, Alfred Marshall. ${ }^{218}$ Later, in his classic text on price theory, the late Nobel laureate George Stigler wrote: "Since the demand for a productive service is indirectly created by the demand for the product in whose production it is used, the demand for the service is said to be a derived demand." ${ }^{219}$ Marshall demonstrated (and Stigler reiterated) that the elasticity of derived demand for an input varies directly with (1) the elasticity of demand for the product that the factor produces; (2) the share of the factor in the cost of production; (3) the elasticity of supply of the other factor(s); and (4) the elasticity of substitution between the factor in question and the other factor(s). ${ }^{220}$

The application of Marshall's rules of derived demand can illuminate whether the demand for a given network element is so inelastic (that is, the quantity demanded is not sensitive to changes in price) that the element

218. See 5 MARSHALL, supra note 15, at 381-93.

219. STIGLER, supra note 16, at 252.

220. Marshall first derived those conditions for the iwo-factor case, given constant retums to scale. See LAYARD \& WALTERS, supra note 15, at 259. 
could be considered necessary. The availability of close substitutes to traditional wireline service such as wireless applications serves to increase the elasticity of demand for wireline service and hence, by Marshall's first rule, tends to increase the elasticity of demand for all of the ILEC's network elements used for voice telephony. As wireless prices approach wireline prices, fixed (as opposed to mobile) customers begin to substitute wireless telephones for landline. Some evidence today already indicates an interest on the part of wireless carriers to serve fixed customers. By February 1999, AT\&T had begun offering digital wireless service in Plano, Texas, in a package designed to attract customers interested in second lines for their businesses or homes. ${ }^{221}$ By offering consumers a forty-dollar monthly package of unlimited local calling bundled with voice mail, caller ID, call waiting, call forwarding, three-way conferencing, and ten-centsper-minute long-distance service, AT\&T has positioned itself to attract second-line customers to its standard wireless service.

For ease of exposition, we apply the remaining rules of derived demand to loops in particular. According to Marshall's second rule, the price elasticity of derived demand for a network element should rise as the share of the element in the network costs rises. The intuition is as follows: Suppose that the price of a network element, which represents a large portion of the total costs, doubles. Because the price of total network costs would rise substantially, the demand for additional network services would fall, and hence the demand for unbundled access to that particular network element would fall. An example of a network element that represents a large portion of the ILEC's total network costs is the loop. Thus, Marshall's second rule implies that the price elasticity of derived demand for loops would be larger than for other network elements, ceteris paribus, and hence unbundled loops would be less likely to be considered necessary for competition.

According to Marshall's third rule, the price elasticity of derived demand for a loop should increase with the elasticity of supply of another network element, such as a switch. Intuitively, the more price elastic the supply of switches, the less the price of switches will fall with a given reduction in the quantity of switches employed, and hence the greater must be the reduction in the quantity of loops employed. As other network elements such as switches and NIDs have become increasingly competitively supplied, ${ }^{222}$ Marshall's third rule of derived demand implies that the price elasticity of derived demand for loops should be rising.

221. See Jennifer Files, AT\&T Test-Markets Mobile Telephone as Alternative to Second Home Line, DALlAS MORNING NEWS, Nov. 12, 1998, available in 1998 WL 16348120.

222. For a discussion of an example of competition in the switching industry. see Susan Breidenbach, Switching Grows up: The Entire Report, NETwORK WORLD (May 4. 1998) <http://www.nwfusion.com/news/0504switch9.html>. 
Finally, according to Marshall's fourth rule, the price elasticity of derived demand for a loop should increase with an increase in the crossprice elasticity of substitution between a loop and other network elements. If network elements are used in fixed proportion, then the cross-price elasticity of substitution between a loop and another network element would be small. In that case, Marshall's fourth rule of derived demand would be the only one of the four rules that does not imply a large price elasticity of derived demand for loops. On the other hand, if technological change permits network elements to be used in variable proportions, substitution will occur across network elements, and Marshall's fourth rule of derived demand will have relevance.

\section{The Relevant Product Market and Critical Share}

The 1992 Merger Guidelines specify that relevant markets for merger analysis may be defined for classes of customers on whom a hypothetical monopolist of the merging firms' products would likely impose a discriminatory price increase. ${ }^{223}$ Although the DOJ and FTC had attempted before 1992 to define markets on the basis of the feasibility of price discrimination, the explicit endorsement of that approach by the 1992 Merger Guidelines has increased the use of this practice by those agencies. ${ }^{224}$ According to the Merger Guidelines, the task of defining the relevant product market when price discrimination is not feasible involves identifying the smallest set of products for which a hypothetical monopolist could profitably raise price a "significant" amount (typically five percent) above the competitive level for a "nontransitory" period of time (normally assumed to be two years). ${ }^{225}$ Thus, under the Merger Guidelines, a potential market definition is too narrow if, in the face of a five percent price increase, the number of customers who would switch to products outside the "market" is sufficiently large to make the price increase unprofitable.

Economists refer to the customers who decide not to purchase the product (or to purchase less of the product) at the increased price as "marginal" consumers. For small price increases, they switch from the products inside the putative "market." Not all customers, however, are

223. See 1992 Horizontal Merger Guidelines, 57 Fed. Reg. $41.552,41.556$ (1992).

224. For recent examples of the use of the price discrimination approach of merger guidelines by the FTC in the petroleum market, see The Exxon-Mobile Merger: Hearings Before the Subcommittee on Energy and Power of the Committee on Conmerce. House of Representatives, 106th Cong. 9-16 (1999) (statement of William J. Baer, Director, Bureau of Competition. Federal Trade Commission). For similar use of the Merger Guidelines with respect to the airline industry, see Comments of the Department of Justice, Joint Application of American Airlines, Inc. and British Airways PLC for Approval of and Antitrust Immunity for Alliance Agreement, No. OST97-2058 (May 21, 1998), available in <http://www.usdoj.gov/atr/public/comments/1777.hum>.

225. 1992 Horizontal Merger Guidelines, $57 \mathrm{Fed}$. Reg. as 41,556. For convenience, we will use the five percent level, although for some purposes a $10 \%$ level may be more appropriate. 
marginal customers. Indeed, in the typical case, most customers would continue to purchase the product despite the higher price because their willingness to pay for the product exceeds the raised price. Economists refer to such customers as "inframarginal" consumers.

In the presence of high demand elasticity and high supply elasticity, a firm cannot exercise unilateral monopoly power by attempting to decrease its supply. ${ }^{226}$ Demand elasticity is captured by a customer's willingness to switch to competing suppliers as relative prices change. Thus, a broad range of available substitutes would imply a high own-price elasticity of demand. Following the same logic as the market definition criteria, the Merger Guidelines provide a concrete test for evaluating the competitiveness of a market as captured in the idea of market power, which is the ability of a single firm unilaterally to increase price above the competitive level for a "nontransitory" period of time. ${ }^{227}$ The Merger Guidelines emphasize the own-price elasticity of demand, while other analyses focus on the cross-price elasticity of demand. But the two elasticity measures are closely related. ${ }^{228}$

Because competition takes place at the margin, only a small proportion of the ILEC's customers need to defect to defeat its attempted price increase. In a simple example, it is possible to calculate that necessary proportion. Suppose that an ILEC attempted to increase prices on end-user access by five percent. How much traffic would that ILEC need to lose before the increase would be unprofitable? The formula to calculate that "critical share" is:

$$
(1-M C / P) Q_{l} \leq(1.05-M C / P) Q_{2}
$$

An important empirical fact for network elements is that fixed costs are a very large component of the overall cost, so that marginal cost is a relatively small component. Assume, for example, that the ratio of marginal cost to price, $M C / P$, is 0.2 . Then $Q_{2}$ would be $0.94 Q_{1}$, so that the critical

226. Demand elasticities and supply elasticities have long been recognized in law and economics as important to assessing the possibility of the exercise of unilateral market power. See, e.g., Landes \& Posner, supra note 14.

227. See 1992 Horizontal Merger Guidelines, 57 Fed. Reg. at 41,556. The other type of monopoly power recognized by the Merger Guidelines is coordinated interaction among all suppliers of a product. Such a possibility is not relevant here because competitors of an ILEC have very different cost structures and product offerings. Moreover, it is far-fetched to imagine firms such as AT\&T and MCI WorldCom attempting to achieve coordination interactions with the RBOCs and GTE.

228. The own-price elasticity of demand is the percentage change in demand when the product's own price is raised by, say, $10 \%$. The cross-price elasticity of demand is the percentage change in demand in response to the change in a competitor's price by, say, 10\%. The two elasticity measures are related by the Slutsky equation in economic theory. The share-weighted (negative) own-price elasticity of demand equals the sum of the share-weighted cross-price elasticities of demand. See, e.g., HENDERSON \& QUANDT, supra note 183, at 22-26. 
share is six percent. Thus, if the ILEC were to attempt to raise its price by five percent, and if, as a result, it were to lose more than six percent of its traffic, the attempted price increase would be unprofitable and thus unilaterally rescinded. ${ }^{229}$

\section{A Proposed Test for the "Impaiment" Standard}

As our discussion makes clear, the existing essential facilities doctrine sets forth necessary but not sufficient conditions for defining "impairment" under $\S 251(\mathrm{~d})(2) .{ }^{230}$ The complete set of necessary and sufficient conditions includes a fifth requirement, responsive to the explicit text of $\S 251$ (d)(2), to address whether the denial of access to that network element at TELRIC prices would impair competition at the end-user level. Our fivepart test is as follows:

The FCC shall mandate unbundling of a network element if, and only if:

(1) it is technically feasible for the ILEC to provide the CLEC unbundled access to the requested network element in the relevant geographic market;

(2) the ILEC has denied the CLEC use of the network element at a regulated price computed on the basis of the regulator's estimate of the ILEC's total element long-run incremental cost;

(3) it is impractical and unreasonable for the CLEC to duplicate the requested network element through any alternative source of supply;

(4) the requested network element is controlled by an ILEC that is a monopolist in the supply of a telecommunications service to

229. For a more extensive discussion of critical share, see Jerry A. Hausman et al.. Market Definition Under Price Discrimination, 64 ANTITRUST L.J. 367 (1996).

230. We have previously argued that the essential facilities doctrine identifies necessary, but not sufficient, conditions for mandatory unbundling at long-run incremental cost. See Hausman. supra note 168, at 22 ("Economic principles suggest that only the 'essential facility' elements of the network, which cannot be economically reproduced in the short nu by new competitors, should be unbundled by regulation."); Paul W. MacAvoy \& J. Gregory Sidak. IWhat Is IVrong with American Telecommunications?. MULTMMEDIA UND RECHT, Mar. 1999, at 15, 15 ("'Surcly it is economic folly to mandate unbundling of any network element that is not 'essential' in the antitrust sense-that is, a network element that cannot be readily duplicated by the entrant or procured at competitive prices from the same vendors who supply the element to the incumbent firm subject to the unbundling obligation."): see also ROBERT W. CRANDALL. MANAGED COMPETITION IN U.S. TELECOMMUNICATIONS 17 (AEI-Brookings Joint Cir. for Regulatory Studies Working Paper No. 99-1. 1999) (" [T]he decision to unbundle everyuhing and to require its leasing at cost-based rates is wildly excessive."). For a similir conclusion by German scholars, applying American antitrust principles to German telecommunications law, see CHRISTOPH ENGEL \& GÜNTER KNIEPS, DIE VORSCHRIFTEN DES TELEKOMIMUNIKATIONSGESETZES OBER DEN ZUGANG ZU WESENTLICHEN LEISTUNGEN (1998); and Christoph Engel. Der IVeg der Deutscher Telekommunikation in den Wettbewerb, MULTIMEDIA UND RECHT, Mar. 1999, al 7, 12-13. As noted earlier, Canada employs an essential facilities approach to mandatory unbundling. See supra text accompanying notes $174-175$. 
end-users that employs the network element in question in the relevant geographic market; and

(5) the ILEC can exercise market power in the provision of telecommunications services to end-users in the relevant geographic market by restricting access to the requested network element.

It is clear that the FCC's requirement of any "technically feasible" unbundling, articulated in the Local Competition First Report and Order, is subsumed within our framework and hence is properly characterized as a necessary, but not sufficient, condition for mandatory unbundling at TELRIC prices. Moreover, we have arranged the order of the requirements in ascending order of magnitude of the resources necessary for analysis. This way, if a CLEC cannot demonstrate that a network element meets the first requirement, then that element is immediately declared inessential, and society is spared the expenditure of the resources needed to perform the more intensive analysis required in the subsequent parts of the test. ${ }^{231}$

To implement the fifth element of our test, one must modify the Merger Guideline's test for unilateral market power only slightly to address the relevant question in the Second Further Notice of Proposed Rulemakingnamely, whether it would impair competition for an ILEC not to sell a particular unbundled network element to a CLEC at a TELRIC price. ${ }^{232}$ Intuitively, our impairment test asks whether the ILEC can exercise market power when restricting access to a particular network element to the CLEC

231. We focus here on the "impairment" standard. As we shall explain presently, our understanding of the "necessary" standard is that it would raise the bar of our five-part test in cases where the desired element embodied some type of intellectual property to which the ILEC had a legally recognizable form of protection.

232. Assume, as the Telecommunications Act requires, see 47 U.S.C.A. $\$ \S 251$ (c)(2)(D), (c)(3), 252(d)(1)(A)(ii) (West Supp. 1999), that the ILEC must charge nondiscriminatory prices for end-user access. If the hypothetical monopolist has the ability to identify the inframargunal customers, it will have the incentive to charge customers different prices depending on their willingness to pay for the product. Thus, even though the hypothetical monopolist may not find it profitable to raise prices five percent above the competitive level uniformly for all its customers, it may find it profitable to raise prices five percent for some of its customers.

Let $c\left(p, u_{n}\right)$ be the critical share of customers that the ILEC must lose to deter the ILEC from raising end-user access above $p$ when all elements except the $n$th network element are avalable to CLECs at competitive prices. For example, $c(30,2)$ indicates the critical share of customers the ILEC must lose to deter the ILEC from raising end-user access above $\$ 30$ when all elements except the second network element are available to CLECs at competitive prices. Additionally, let $q(p)$ be the residual demand for end-user access faced by the ILEC for any given end-user access price $p$. We are now ready to state our proposed test for the "impairment" standard of $\S 251(\mathrm{~d})(2)$ :

Impairment Test: Assume within a market that, by regulatory fiat, the ILEC must charge nondiscriminatory prices. The regulator should mandate unbundling of some network element $n$ at its TELRIC price only when $1-[q(1.05 p) / q(p)]<c\left(p, u_{n}\right)$.

Stated another way, if the share of departing ILEC customers, $1-[q(1.05 p) / q(p)]$, exceeds the critical share that the ILEC can profitably sustain, $c\left(p, u_{n}\right)$, then the ILEC could not exercise market power. 
in a particular geographic market. If the ILEC cannot exercise market power (in the output market) when declining to offer a particular network element at a TELRIC price, then all of the consumer benefits associated with a competitive outcome have already been secured. Therefore, the regulator should not order the network element in question unbundled. In contrast to the method employed by the Commission, our test is focused on protecting competition as opposed to competitors.

Which market forces might prevent the ILEC from successfully implementing that price increase? There are at least three such forces. First, if the ILEC attempts to raise the output price, CLECs will find it profitable to increase their supply of the output. CLECs could self-supply the network element in question (for example, switches) or purchase the use of the element from non-ILEC sources (for example, transport). Second, if the ILEC raises prices, customers will shift their demand to competing forms of access, such as cable telephony or wireless for residential customers and competitive access providers for business customers. With its proposed acquisitions of MediaOne and TCI and its proposed joint venture with Time-Warner, AT\&T has positioned itself to serve ninety-five percent of all households in the United States. It is not rational to claim that AT\&T, MCI WorldCom, and all the other CLECs would conspire to keep landline access prices above the competitive level. Thus, the "critical share" analysis described above would indicate that, in many situations, CLECs would find it profitable to replace the ILEC's reduction in supply and thereby defeat any attempted exercise of unilateral market power by the ILEC. Third, falling wireless prices will continue to displace traditional wireline users. Those three constraining forces make it implausible that the ILEC could exercise market power as defined by the Merger Guidelines. If market forces can protect consumers from the harms of monopolization, then the Commission should not impose mandatory unbundling.

Some might argue that the Merger Guidelines approach simply highlights the ILECs' high market shares for certain services, such as residential access. But that reasoning is fallacious. Professor William Landes and Chief Judge Richard Posner some time ago noted that high market shares in a price-regulated industry are either meaningless from a competitive perspective or indicative of prices that are set at or below marginal cost-that is, at or below the price that would obtain in a competitive equilibrium:

To the extent that regulation is effective, its effect is to sever market power from market share and thus render our analysis inapplicable. This is obviously so when the effect of regulation is to limit a monopolist's price to the competitive price level. A subtler effect should also be noted, however. Regulation may increase a firm's market share in circumstances where only the appearance 
and not the reality of monopoly power is created thereby. For example, in many regulated industries firms are compelled to charge uniform prices in different product or geographical markets despite the different costs of serving the markets. As a result, price may be above marginal cost in some markets and below marginal cost in others. In the latter group of markets, the regulated firm is apt to have a $100 \%$ market share. The reason is not that it has market power but that the market is so unattractive to sellers that the only firm that will serve it is one that is either forbidden by regulatory fiat to leave the market or that is induced to remain in it by the opportunity to recoup its losses in its other markets, where the policy of uniform pricing yields revenues in excess of costs. In these circumstances, a $100 \%$ market share is a symptom of a lack, rather than the possession, of market power. ${ }^{233}$

That assessment is directly relevant to the familiar assertion that an ILEC must possess market power because it has a high share of customers for a particular service. That reasoning is incorrect. Professor Landes and Chief Judge Posner noted that in such a case "the causality between market share and price is reversed. Instead of a large market share leading to a high price, a low price leads to a large market share; and it would be improper to infer market power simply from observing the large market share." ${ }^{234}$ The Ninth Circuit described that relationship well when it said that "[r]eliance on statistical market share in cases involving regulated industries is at best a tricky enterprise and is downright folly where ... the predominant market share is the result of regulation. In such cases, the court should focus directly on the regulated firm's ability to control prices or exclude competition." 235 Our proposed test for the "impairment" standard would provide that proper focus. Moreover, our "impairment" test would provide the FCC with a mechanism "for removing particular elements from the unbundling requirements" ${ }^{236}$ and for declining to subject particular elements to mandatory unbundling in the first place.

\section{A Proposed Test for the "Necessary" Standard}

As we noted in Part II, the elements of the test for establishing "impairment" are necessary, but not sufficient, conditions for the mandatory unbundling of a network element that is "proprietary in nature."

233. Landes \& Posner, supra note 14 , at $975-76$.

234. Id. at 976 .

235. Metro Mobile CTS v. NewVector Communications, 892 F.2d 62, 63 (9th Cir. 1989) (citations omitted); accord Consolidated Gas Co. v. City Gas Co., 880 F.2d 297, 300 (I Ith Cir. 1989), aff'd on reh'g, 912 F.2d 1262 (11th Cir. 1990), rev'd per curiam on other grounds. 499) U.S. 915 (1991).

236. Second Further Notice of Proposed Rulemaking, supra note 3, $\$ 37$. 
For any element embodying a form of legally protected intellectual property, the "necessary" standard of $\S 251$ (d)(2) would apply. For such an element, the Commission should recognize that a heightened standard, beyond impairment of competition, should apply because of the importance to consumer welfare of innovation that leads to the creation of intellectual property and because of the uncertainty of success that is inherent in the innovative process. ${ }^{237}$ For these purposes, we accept as relevant to $\S 251$ (d)(2) the definition of intellectual property contained in the Antitrust Guidelines for the Licensing of Intellectual Property, issued in 1995 by the Department of Justice and the Federal Trade Commission. ${ }^{238}$

Although, as noted in Part II, the Commission relied on a dictionary definition for "impairment," it appears to have defined "necessary" without any similar reliance on a dictionary. The FCC stated: " 'Necessary' means, in this context, that an element is a prerequisite for competition." 239 The proper dictionary definition of "necessary," however, is considerably more emphatic than the FCC's definition. The Oxford English Dictionary gives "necessary" the following primary definition: "[i]ndispensable, requisite, essential, needful; that cannot be done without." 340 Similarly, Webster's defines "necessary" as "[a]bsolutely required: indispensable."

The Commission then compounded its definitional problems by incorrectly subsuming "necessary" within the definition of "impair": "We believe that, in some instances, it will be 'necessary' for new entrants to obtain access to proprietary elements (e.g., elements with proprietary protocols or elements containing proprietary information), because without such elements, their ability to compete would be significantly impaired or thwarted." 242 By principally relying on "impairment" to define "necessary," the Commission created a logical circularity that failed to differentiate the two requirements.

While our impairment-of-competition standard is based on the ability of an ILEC to exercise significant market power for a service in the absence of unbundling, in the case of a proprietary element based on intellectual

237. It has long been recognized in the economics literature that the private incentive to innovate is too low relative to the socially optimal outcome that maximizes consumer welfare even when a patent is granted. See, e.g., JEAN TIROLE. THE THEORY OF INDUSTRLAL ORGANIZATION 389-414 (1988). The FCC will further decrease the already insufficient incentive to innovate if it requires mandatory unbundling of elements based on intellectual property and requires thern to be sold at TELRIC-based prices.

238. See Antitrust Guidelines for the Licensing of Intellectual Properny. 4 Trade Reg. Rep. (CCH) 13,132, at 20,734 \& n.1 (Apr. 11, 1995). The Guidelines state: " The intellectual property laws and the antitrust laws share the common purpose of promoting innovation and enhancing consumer welfare." Id. at 20,734.

239. First Report and Order, Implementation of the Local Competition Provisions in the Telecommunications Act of 1996, 11 F.C.C.R. 15.499. 1282 (1996).

240. 10 OXFORD ENGLISH DICTIONARY 276 (2d ed. 1989).

241. WEBSTER'S II NEW RIVERSIDE UNIVERSITY DICTIONARY 787 (1988).

242. First Report and Order, 11 F.C.C.R. 9282. 
property we recommend a standard that provides for unbundling only if competition is impossible in the absence of unbundling. Thus, an ILEC might retain some degree of market power based on the intellectual property, as currently happens with respect to intellectual property in the rest of the economy. ${ }^{243}$ However, so long as competition is possible without the use of the ILEC's intellectual property, economic incentives will exist for ILECs and CLECs to negotiate an agreement over terms because the ILEC will not be able to control competitive entry into the market for end-user services through its control of the intellectual property. We refer to our approach for proprietary elements based on intellectual property as the "absolutely essential" standard because unbundling is appropriate only when the element is truly necessary for competition.

\section{APPLYING THE PROPOSED TEST FOR "IMPAIRMENT" TO SPECIFIC NETWORK ELEMENTS}

The consumer-welfare approach described in Parts IV and V not only guides our understanding of the "necessary" and "impair" standards, but also lends itself naturally to a decision framework for determining whether a particular network element in a particular market requires unbundling. We now apply our impairment test to the seven network elements in the Second Further Notice of Proposed Rulemaking, as well as to several additional network elements that either embody new technologies or make possible new services. We understand Justices Scalia and Breyer to imply that there is an established body of antitrust case law that provides guidance for the application of the first four parts of our impairment test. Thus, we focus primarily on how the fifth part of our test should be applied to network elements. The clear point that emerges from this analysis is that determining whether a particular network element in a particular geographic area is actually an essential facility requires a close empirical investigation of the specific facts in that geographic market. In the sections that follow, we explain why demand-side constraints on market power apply to all of the ILEC's network elements in general, while supply-side constraints can be analyzed at the level of specific network elements.

243. See, e.g., David J. Teece \& Mary Coleman, The Meaning of Monopoly: Antitrust Analysis in High-Technology Industries, 43 ANTITRUST BULL. 801, 820-22 (1998) (discussing entrepreneurial rents derived from innovation). 


\section{A. The Influence of Supply-Side Effects on the Unbundling of Specific Network Elements}

From a supply-side perspective, the correct way to assess whether an ILEC has the ability to exercise monopoly power is to ascertain the following: If the ILEC attempted to restrict its supply of a given network element to increase the price of end-user services above competitive levels, would other providers increase their supply of that network element or competing network elements sufficiently to defeat the attempted price increase? If competitors have no barriers to expansion or can gain access to the network element from an alternative source, then the ILEC cannot exercise market power in the end-user service market by restricting the supply of a given element. ${ }^{244}$ Typically, a competitor providing a network element will have no binding capacity constraints and it will be able economically to increase its supply of a given element at current prices. Since marginal costs are not increasing for provision of network elements, a firm's current provision of a UNE will demonstrate its ability to expand supply. ${ }^{245}$ Thus, for a given network element for which competitive supply exists, an ILEC will be unable to exercise market power in most situations.

The Supreme Court ruled in Iowa Utilities Board that the FCC needed to consider the availability of network elements from altemative suppliers to the ILEC in determining whether the ILEC's supply of a particular network element met the "necessary" and "impair" standards. ${ }^{2+6}$ Thus, an economic analysis of the expected supply of a given network element would be required for the Commission to make a reasoned determination. Because of the underlying technology of network elements for which fixed costs are high relative to marginal (or variable) costs, the economic incentives for non-ILECs that have entered the market to expand their supply will be very high. With high supply elasticity from competing firms, the ILEC will not likely be able to exercise market power in the supply of network elements.

Our impairment test is necessarily stated in the abstract. Regulators attempting to employ our standard, however, may require simple, objective market characteristics that would serve as proxies for constraints on an ILEC's ability to exercise market power. With respect to supply-side substitution constraints, two market characteristics should be incorporated.

244. The following analysis responds to the FCC's request for " comment on when we should deem a substitute sufficiently available so as to render access to the incumbent's network element unnecessary." Second Further Notice of Proposed Rulemaling. supra note 3. 9 21; see also id. 9 24 (asking "how the Commission should consider the availability of network elements outside of the incumbent's network").

245. Indeed, marginal costs are either constant or decreasing for most UNEs. Otherwise, we would expect to see numerous small competitors entering the market to supply UNEs.

246. See AT\&T Corp. v. Iowa Utils. Bd., 119 S. Ct. 721.735 (1999). 
First, regulators should examine whether a CLEC is self-supplying the element in question in the relevant geographic market. If at least one CLEC is supplying the element in question, the ILEC cannot exercise market power in the end-user services market by restricting access to that element. If the element is not competitively supplied, regulators should next examine the nature of the costs of the network element to determine whether the element could be competitively supplied in the short term. In particular, if fixed (as opposed to sunk) costs represent a large share of the total costs of the element in question, then the element should not be unbundled. As explained in Part IV, as long as the asset can be redeployed in a different geographic market at little cost, the CLEC will face no exit barriers. Because low exit costs encourage entry, the regulator need not rely on unbundling of that network element to stimulate competition. ${ }^{247}$

Furthermore, as a network element becomes competitively supplied, TELRIC pricing better approximates the element's market value. But the proper measure of TELRIC incorporates the value of the option associated with the forward-looking nature of the investment. ${ }^{248}$ The competitive price and the element's TELRIC converge to the same value when only fixed costs but not sunk costs are present in the element, because the value of the option under those circumstances converges to zero. Thus, we would predict a socially perverse relationship between the sunk-cost nature of the ILEC's network investment on the one hand, and the CLEC's demand for mandatory unbundling on the other hand. The more likely it is that TELRIC accurately approximates the market-determined price of an unbundled network element, the less likely it is that the CLEC will demand mandatory unbundling of that element, because the value of the free option granted to the CLEC by the Commission will be near zero. Conversely, the less likely it is that TELRIC fully compensates the ILEC for the option value of mandatory unbundling of a particular network element when sunk costs are important, the more likely it is that the CLEC will demand mandatory unbundling of that element at a TELRIC-based price. This perverse effect flows from the FCC's failure to recognize the substantial option value that is associated with the CLEC's right to compel sharing of the ILEC's sunk investments in network infrastructure. The effect of the option value on the CLEC's demand for mandatory unbundling is in addition to the "reverse Cellophane" effect described

247. It is well recognized that a barrier to exit becomes a barrier to entry. For a discussion of the absence of exit barriers in the wireless industry because fixed investment is amenable to redeployment by other firms or in other geographic markets, see SIDAK \& SPULBER, supra note 4. at 78-79.

248. To a limited extent, the Commission recognized this notion of cost in its 1996 interconnection proceeding. See First Report and Order, Implementation of the Local Competition Provisions in the Telecommunications Act of 1996, 11 F.C.C.R. 15,499, TI 638-52. 686-95 (1996) (discussing testimony of Jerry Hausman). For further discussion, see Hausman, supra note 168, at 24-26; Hausman, supra note 12, at 26-35. 
earlier, ${ }^{249}$ which occurs whether or not the element in question embodies sunk costs.

1. The Supply of Existing Network Elements Listed in the Local Competition First Report and Order

We now consider how our impairment test would apply to the two most significant of the seven network elements listed in the Local Competition First Report and Order. The first such element, local switching, illustrates how our test would apply to an element with primarily fixed but not sunk costs. The second network element, an unbundled loop, involves a relatively greater degree of sunk costs. After we have shown how the analysis would differ between elements depending on their degree of fixed versus sunk costs, we then briefly explain why the remaining five elements would require a regulatory commission to undertake geographically specific factfinding before it could conclude whether or not those elements meet the impairment standard of $\S 251(d)(2)$. Recall that in this Subsection, we consider only supply-side substitution constraints on an ILEC's ability to exercise market power in the end-user services market.

\section{a. Local Switching}

The switch is a telephone company's central computer that processes cross-connections for telephone calls and makes routing decisions on the basis of some parameter, such as the digits dialed by the customer. ${ }^{200}$ The nature of costs for switches and the level of competition in their supply indicate, for at least three reasons, that switches should not be unbundled in any geographic market in the United States. First, switches are already competitively supplied. As of March 1999, over one-third of all RBOC and GTE rate centers in the United States were served by at least one CLEC voice switch, and eighteen percent were served by at least two CLEC switches. ${ }^{251}$

Second, even if one were to assume that switches were not competitively supplied, the nature of their costs would still indicate that switches should not be unbundled. In particular, switches are highly substitutable across wide geographic areas. If a local switch is combined with digital loop carrier equipment, the switch can provide service to distant

249. See supra text accompanying notes 184-185.

250. See Regis J. Bates \& DONALd GRegory, Voice and Data Communications HANDBOOK 31 (1998).

251. See Peter W. Huber \& Evan T. Leo. UNE Fact Repon. FCC 96-98 (May 26. 1999) (submitted by United States Telephone Association and prepared for Ameritech. Bell Atlantic. BellSouth, GTE, and U S WEST) (on file with The Yale Law Journal). 
customers. At a certain point, the cost of transporting calls to a distant switch becomes more costly than the benefits achieved from the scale economies of increasing the switch load. According to AT\&T, such an arrangement (combining the local switch with digital loop carrier equipment) is feasible within a 125-mile radius from the switch. ${ }^{252}$ Consequently, the relevant geographic markets for switching are large.

Third, it is economically feasible for competitors to self-supply (buy and install) switches across a wide range of geographic areas. As long as a CLEC believes that it can serve the minimum number of access lines needed to operate the switch in an economic fashion, self-supply is a viable alternative. Because there are no barriers to exit in the switch industry, mandatory unbundling of switches would not increase competition and therefore could not improve consumer welfare.

\section{b. Unbundled Loops}

In general, loops are much less substitutable than switching because a large portion of the facility is dedicated to an individual customer, or at least to a specific street or neighborhood, and is costly to redeploy. But in many suburban areas there are facilities-based local competitors for business services. Indeed, unbundled loops for businesses in downtown areas and other areas where CLECs (or competitive access providers, as they were formerly known) provide service cannot satisfy the "necessary" or "impair" standard. Supply-side analysis shows that it cannot impair competition to decline to lease unbundled loops to those firms at TELRIC prices. Over time, those CLECs should spread their service to residential customers as well. In some geographic areas, facilities-based competitors already serve residential customers.

Given the pace of new technology deployment, suburban and even rural markets need to be analyzed on a case-by-case basis to determine whether and where unbundled loops are essential facilities. Even if one considers only the constraints on market power due to CLEC supply opportunities, unbundled loops may be essential facilities in some markets but not in others. ${ }^{253}$ The Second Further Notice of Proposed Rulemaking, however. presumes that loops must be unbundled: "It is our strong expectation that under any reasonable interpretation of the 'necessary' and 'impair' standards of $\S 251$ (d)(2), loops will be generally subject to the $\S 251$ (c)(3) unbundling

252. See Petition of AT\&T Corp. To Deny Application, GTE Corp. \& Bell Atlantic Corp. for Consent to Transfer of Control, FCC 98-184, at 24 (Nov. 23, 1998) (on file with The Yale Law Journal).

253. This section addresses only supply-side effects. With respect to demand-side constraints on market power, as soon as AT\&T begins to supply cable telephony, unbundied loops should no longer meet the impairment test. At that time, an ILEC should no longer be compelled to supply CLECs unbundled loops at a TELRIC price. 
obligations." 254 If the Commission were to incorporate demand-side substitution possibilities, as we do in the following section, the agency would have to revise its expectation that mandatory unbundling of loops will be necessary.

\section{c. Other Network Elements}

As the preceding discussion shows, the question of whether or not to mandate unbundling of a network element depends on factual questions concerning the level of actual competition in the supply of the requested element and the degree to which the costs of the element are sunk or fixed. The answers to those questions are likely to vary from one geographic market to another for the reasons we have discussed earlier. For four of the five remaining elements-namely, NIDs, interoffice transmission facilities, signaling networks, and operations support systems-the regulatory commission would have to undertake geographically-specific fact finding before it could conclude whether or not those elements are competitively supplied, and if not, whether they could be competitively supplied in a reasonable period of time. Finally, we believe operator services and directory assistance, the remaining element, need not be unbundled in any geographic market because they are competitively supplied, as one state PUC recently concluded. ${ }^{255}$

\section{New Technologies for Which the FCC Potentially Could Mandate Network Unbundling}

Market evidence demonstrates that mandatory unbundling of the ILECs' broadband networks and the services they deliver is not required to permit competition. Because an ILEC does not have market power in the delivery of broadband services, the network elements that the ILEC uses to supply those services cannot be essential facilities. Competition in broadband services is underway without any compulsory unbundling of the ILECs' network elements. Indeed, in its 1999 report to Congress on the deployment of advanced telecommunications capabilities, the Commission recognized the current state of broadband competition that exists without any use of ILEC network elements:

Numerous companies in virtually all segments of the communications industry are starting to deploy, or plan to deploy in

254. Second Further Notice of Proposed Rulemaking. supra note 3. 132.

255. See Order Granting Petition, Petition of U S WEST Communications, Inc. for Competitive Classification of its Directory Assistance Services. Dkt. UT-990259 (Wash. Utils. \& Transp. Comm'n Apr. 29, 1999), available in 1999 Wash. UTC LEXIS 346. 
the near future, broadband to the consumer market. Current providers include cable television companies, incumbent LECs, some utilities, and "wireless cable" companies. ${ }^{256}$

Because cable companies' lines currently pass more than ninety-five percent of U.S. homes, it follows that mandatory unbundling of the ILECs' broadband networks is not necessary for competition in broadband services, nor would competition be impaired if the ILECs' broadband networks were not unbundled.

Furthermore, although the ILECs' loops in certain geographical areas may be subjected to mandatory unbundling under the impairment standard, as we discussed above, the ILECs' broadband backbone facilities should not be unbundled. Again, the Commission recognized in its 1999 report to Congress that competition is proceeding without mandatory unbundling of the ILECs' broadband networks: "We consider investment in both backbone facilities and the 'last mile.' We find that broadband backbone facilities are being deployed in a reasonable and timely manner." ${ }^{257}$ In the same report to Congress, the FCC also observed:

Deployment of broadband, both backbone and last mile, is occurring on a major scale, for both business and consumer markets. American business and the capital markets are obviously betting that broadband will be successful in the business and consumer markets and many companies are rushing to seize part of that success. We expect that this sizeable investment by numerous companies will translate in the near future into significant deployment of broadband capability. ${ }^{258}$

Regulatory intervention is not required when competition is thriving, and unnecessary regulation can distort otherwise competitive markets. Thus, if the Commission applies to $\S 251(\mathrm{~d})(2)$ a competition-based consumerwelfare standard, as we have urged, rather than a competitor-welfare standard, the factual findings in the Commission's own 1999 report to Congress demonstrate that no unbundling of the ILECs' broadband networks should be required.

Furthermore, mandatory unbundling of the ILECs' broadband networks at TELRIC-based costs would very likely decrease innovation and the introduction of new broadband services to consumers for the reasons that we discussed previously. An ILEC is unlikely to invest in a new broadband service if it knows that the FCC will compel it to sell to its competitors at

256. Inquiry Concerning the Deployment of Advanced Telecommunications Capability to All Americans in a Reasonable and Timely Fashion, 14 F.C.C.R. 2398, 12 (1999).

257. Id. 13 (footnote omitted).

258. Id. 136 . 
TELRIC prices the network elements used to supply that service if the service proves to be commercially successful. The Commission seems to be oblivious of the impact of mandatory unbundling on ILEC investment in advanced services:

We also see nothing in the statute or the Supreme Court's opinion that would preclude us from requiring that loops that must be unbundled must also be conditioned in a manner that allows requesting carriers supplying the necessary electronics to provide advanced telecommunications services, such as digital subscriber line technology $(x D S L) .{ }^{259}$

The Commission's gift of a free option to CLECs is not costless to society as a whole, for it will decrease innovation and thereby harm consumers, contrary to the explicit goals of the Telecommunications Act of 1996.

\section{Combinations of Elements}

Our test can be adapted to evaluate combinations of elements. The Commission stated in its Second Further Notice of Proposed Rulemaking that "[t]he ability of requesting carriers to use unbundled network elements, including combinations of unbundled network elements, is integral to achieving Congress' objective of promoting rapid competition in the local telecommunications market." 260 Our proposed impairment test, as described earlier, supposes that all but a single network element are competitively supplied to CLECs. If the CLEC can demonstrate that the ILEC's restriction of unbundled access to the remaining element at a TELRIC price would allow the ILEC to exercise market power in the output market, then that element should be unbundled at its TELRIC price. Stated differently, our impairment test is conducted on a "stand-alone basis." One may argue, however, that our test does not consider cases where sets of network elements are not competitively supplied. In those circumstances, would competition in the output market be impaired? Two cases must be considered.

First, suppose two network elements failed to meet the impairment test on a stand-alone basis. If it would not impair the competitive supply of telecommunications services for the FCC to refrain from mandating the unbundling of a nonproprietary element, then it necessarily follows that such an element is one that, when assembled with other elements that failed to pass the impairment test on a stand-alone basis, produces a competitive service that

259. Second Further Notice of Proposed Rulemaking, supra note 3. q 32; see also id. 134 (seeking comment on whether to "modify the definition of 'loops' or 'transpor' to include dark fiber"); id. 135 (seeking comment on mandatory unbundling of DSLAMs and packet switches).

260. Id. $\mathbf{9} 2$. 
the FCC should forbear from regulating entirely. In those cases, the set of network elements should not be unbundled at TELRIC prices.

Second, suppose that one network element, $A$, failed to meet the impairment test on a stand-alone basis, while the restriction of access to another network element, $B$, was shown to impair competition at the output level. The Commission might reason in the following way: Element $A$ failed the impairment test only because the CLEC could rely on element $B$ in the hypothetical. Recall that all other network elements are assumed to be competitively supplied in the stand-alone test. In those cases, the burden of proof should be on the CLEC to demonstrate that the cost of supplying element $A$ conditional on supplying element $B$ is sufficiently less than the cost of supplying element $A$ alone. If the CLEC could not demonstrate significant cost synergies, then element $A$ could not be reclassified as essential.

Finally, consider the case of the "UNE platform," where all of the ILEC's network elements are considered simultaneously as a single "element." The logic developed earlier implies that as long as any one element of the UNE platform fails to meet the impairment test on a stand-alone basis, the UNE platform as a whole should not be unbundled at TELRIC prices. The only condition under which the UNE platform should be unbundled at TELRIC prices is when each of the elements of the UNE platform individually passes the impairment test on a stand-alone basis. For the reasons discussed above, that condition cannot hold in the face of the clearly competitive supply of elements such as switching and directory assistance.

\section{B. The Influence of Demand-Substitution Effects on the Unbundling of All Network Elements}

In contrast to the supply-side effects articulated above, the demand-side effects do not influence each network element on an individual basis. From a demand-side perspective, the correct way to assess whether an ILEC has the ability to exercise monópoly power is to ascertain the following: If the ILEC attempted to raise prices for end-user access while restricting its supply to CLECs of a given network element, would consumers find an alternative source of acceptable end-user service? Consumers could make that choice without considering whether a particular network element or set of network elements was competitively supplied to CLECs. Any consumer substitution in response to an increase in the price of end-user services constrains the ILEC's market power across all network elements. Demand elasticity at the output level does not differentially affect individual network elements at the input level. Thus it would be unproductive for the FCC to 
attempt to apply this portion of the impairment test at an element-specific level.

It is well-known that the price elasticity of demand for any good increases with the availability of suitable substitutes. ${ }^{201}$ In recent years, credible substitutes for traditional landline service have begun to emerge that should increase the price elasticity of demand for traditional voice telephony services. For example, Cox Cable is offering local telephony service over its coaxial cable plant in parts of Orange County and San Diego, California; Phoenix, Arizona; Omaha, Nebraska; Hampton Roads, Virginia; and parts of New England. ${ }^{262}$ AT\&T's recent purchase of TCI, its bid for Media One, and its alliance with Time Warner would give the firm access to fifty-five percent of cable customers in the United States. ${ }^{263}$

In addition to cable, wireless technologies are being deployed in an increasing number of geographic areas. For example in Plano, Texas, AT\&T's "Wireless Home Phone Option" is designed to compete directly with the local exchange service of the wireline incumbent, GTE. The plan offers unlimited airtime within the fixed local calling area (that is, the home cell site) at a price comparable to GTE's basic service. Also, AT\&T is testing a fixed wireless local loop, known as "Project Angel," that is designed to fill in coverage gaps in AT\&T's cable network. AT\&T can provide users with up to four telephone lines, each capable of carrying voice, high-speed data, and video through an antenna-like device installed outside the user's house. ${ }^{264}$ Wireless local loops are likely to be the preferred access technology in rural areas because they are a cost-effective way to transmit signals to remote residences. For example, in Regent, North Dakota, fixed wireless services from Western Wireless allow customers to connect regular home telephones to wireless base station units in order to get competitively priced local and long-distance services while effectively bypassing the wireline local loop. ${ }^{265}$ Such developments in the demand substitutability of alternative access technologies provide a clear answer when the FCC asks in the Second Further Notice of Proposed Rulemaking about "the relevance, if any, to the interpretation of the 'necessary' and 'impair' standard, that we are reexamining these issues today, more than three years after passage of the [Telecommunications] Act." 266

261. See, e.g., STIGLER, supra note 16 , at 24 .

262 See Alex Best, Senior Vice President, Engineering, Cox Communications, Presentation at 1999 Fifth Annual Goldman Sachs Communications Technology Retreat (Mar. 1. 1999) (on file with The Yale Law Joumal).

263. See Paul Farhi, AT\&T: Too Big Once Again?, WASH. POST, Apr. 27, 1999, at El. AT\&T would pass a much higher percentage of homes.

264. See Rebecca Blumenstein, AT\&T Plans To Enter Some Areas Using "Fixed Wireless" Technology, WALI ST. J., Mar. 19, 1999, at B6.

265. See Joe Gandyasz, Phone Co-Op Pulls Plug on Wireless Competitor, BisMarCK TriB., Jan. 13, 1999, at 5 .

266. Second Further Notice of Proposed Rulemaking, supra note 3. 914. 
The first competitive constraint on any exercise of ILEC market power is cable telephony. Wireless telephony is an additional constraint on market power. Barring any coordinated interaction among firms providing competitive technology platforms, competition in voice telephony should be robust, and demand substitutability should be high. Thus, little regulatory intervention is warranted.

Demand-substitution constraints on the ILEC's ability to exercise market power also may come from consumers' demand for bundles of services that include local voice telephony. As the FCC acts according to a belief that competition requires extensive mandatory unbundling at TELRIC prices, competitors of the ILECs pursue a business strategy of acquiring (through the capital market) network elements at market prices, on the assumption that consumers demand bundled services.

An unstated premise of the FCC's interpretation of the mandatory unbundling provisions in $\S 251$ and $\S 252$ of the Telecommunications Act of 1996 seems to have been that those statutory provisions should be read in a demand-substitution vacuum. Although the Telecommunications Act ostensibly removed artificial regulatory distinctions based on the particular technology employed to produce a communications service, the administrative rulemakings and federal court litigation that dominated the first three years of experience under the new statute focused on the traditional narrowband wireline access network. Indeed, developments in cable telephony and wireless local loops may soon make the entire exercise of wireline unbundling irrelevant. Yet, far from considering the relevance of demand substitution to interpretation of $\$ 251(\mathrm{~d})(2)$, the Second Further Notice of Proposed Rulemaking asks whether the FCC should truncate its analysis of all relevant sources of supply substitution. ${ }^{267}$ The FCC evidently does not contemplate any evaluation of demand substitution whatsoever.

It is inconsistent for the FCC to emphasize forward-looking TELRIC costs for pricing unbundled network elements and yet retain a backward-looking view of product definitions and demand substitution for telecommunications services. Put differently, it is not "forward-looking" for the FCC to presume that a current product definition for telecommunications service will remain constant over time, especially when there is strong evidence that the bundling of services may redefine the relevant product market for purposes of competitive analysis. In discussing the problems created by TELRIC pricing for unbundled network elements, one of us observed in 1997:

267. See id. I 28 (asking "whether and the extent to which the language of the statute and the Supreme Court's opinion constrain the factors that we can or should consider in evaluating the availability of elements outside the incumbent's network"). 
Like Janus, regulators alternate between past and future perspectives on markets as doing so serves their purpose. The result, which we call the Janus artifice, is an inconsistent economic analysis of competition and pricing. When evaluating the prospects for competition, regulators often look to the past, emphasizing the sunk costs of the incumbent LECs and past market share. For pricing purposes, however, regulators look to the future, promoting their notion of forward-looking costs. Regulators can only compound the fallacies inherent in the forward-looking cost approach when they engage in shifts in perspective that are meant to facilitate desired policy outcomes. ${ }^{268}$

In contrast, antitrust analysis implies that the relevant product markets for an end product or an essential facility must be continually revised over time. Given those considerations and the growth of bundled services successfully offered by the ILECs' competitors, the FCC runs the risk that its unbundling policy will be irrelevant to competition before it is even fully implementedand thus obsolete and harmful to consumer welfare.

\section{The Relationship Between an "Efficient-Competitor" Standard and the Consumer-Welfare Standard}

We have argued at length that the FCC should use consumer welfare, not competitor welfare, as the touchstone for interpreting the "impairment" standard of $\S 251(\mathrm{~d})(2)$. That said, suppose that the Commission nonetheless inclined toward a competitor-welfare approach, but attempted to mitigate the harm that such an approach would impose on consumers by mandating unbundling only if the CLEC were deemed to be an efficient competitor. In other words, the FCC would ask whether the ILEC's failure to unbundle the network element at a TELRIC-based price would impair an efficient competitor's ability to provide telecommunications services to end users. What would be the practical difference between an efficient-competitor standard and the consumer-welfare test that we propose? How would the FCC or a reviewing court reconcile the two seemingly disparate techniques?

To compare the two approaches, it is useful first to ariculate the circumstances under which both standards would produce the same result for a given unbundled network element. Recall that our five-part consumerwelfare standard asks whether the ILEC can exercise market power in the output market for end-user services. That is, can the ILEC raise prices in the output market in a nontrivial way for a nontransitory period of time? In contrast, the efficient-competitor standard focuses on competition in the

268. SIDAK \& SPULBER, supra note 4, at 425. 
input market and asks whether there is a competitive supply of network elements. It is critical to recognize, however, that competition in the output market does not depend solely on the level of competition for one of the inputs. Competition in the input market is a sufficient, but not necessary, condition for competition to be effective in the output market.

Thus, whenever competition exists in the input market for a particular network element, both the efficient-competitor and the consumer-welfare standards will indicate that mandatory unbundling would be inappropriate. According to the efficient-competitor standard, a CLEC could, under those conditions, self-supply the network element or purchase it at competitive rates and thereby effectively compete against the ILEC. Similarly, the consumer-welfare standard would indicate that, under those conditions, the ILEC would be constrained from exercising market power in the end-user services market by attempting to deny a CLEC access to the competitively supplied network element in question.

Under other conditions, however, the two standards would produce divergent outcomes. Suppose that within a well-defined geographic market the ILEC is the sole supplier of the network element requested by a CLEC. Suppose further that, within the same geographic market, the ILEC faces intense competitive pressure in the end-user services market from AT\&T in the form of voice telephony provided over TCI's coaxial and fiber-optic infrastructure. Under those circumstances, the efficient-competitor standard would indicate mandatory unbundling of the requested network element. To the contrary, the consumer-welfare standard would indicate that no mandatory unbundling of the network element in question would be warranted. That example highlights the major shortcoming of the efficientcompetitor standard-it ignores that alternative sources of supply in the output market constrain the ILEC's ability to exercise market power. It is clear from the Second Further Notice of Proposed Rulemaking that, consistent with an efficient-competitor standard, the FCC's approach to interpreting $\S 251$ (d)(2) incorrectly focuses on competition in the input market while ignoring competition in the output market. ${ }^{269}$ The Table summarizes the differences in outcomes that would result under TELRIC prices from the Commission's use of the consumer-welfare standard, the efficientcompetitor standard, and the original standard in the Local Competition First Report and Order.

269. See Second Further Notice of Proposed Rulemaking, supra note 3, 942 (" [W]e seck comment on whether the existence of a competitive market for a network element is necessary to demonstrate that an element is sufficiently available outside the incumbent's network so that failure of the incumbent to provide the element would not be 'necessary' or would not 'impair' a carrier's ability to provide service."). 
TABLE: COMPARISON OF THE OUTCOMES RESULTING FROM THE APPLICATION OF THREE DIFFERENT STANDARDS FOR MANDATORY UNBUNDLING AT TELRIC PRICES

\begin{tabular}{|c|c|c|c|}
\hline 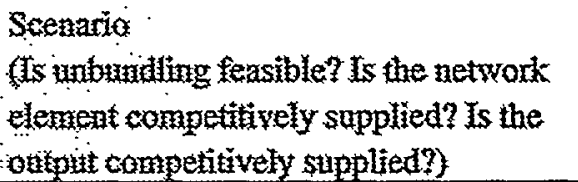 & $\begin{array}{l}\text { Technical- } \\
\text { Feasibility } \\
\text { Standard }\end{array}$ & $\begin{array}{l}\text { Efficient- } \\
\text { Competitor } \\
\text { Standard }\end{array}$ & $\begin{array}{l}\text { Consumer- } \\
\text { Welfare } \\
\text { Standard }\end{array}$ \\
\hline $\begin{array}{l}\text { Unbundling is not technically feasible, } \\
\text { UNE is competitively supplied, output is } \\
\text { competitively supplied (N, Y, Y) }\end{array}$ & $\begin{array}{c}\text { Do Not } \\
\text { Unbundle }\end{array}$ & $\begin{array}{l}\text { Do Not } \\
\text { Unbundle }\end{array}$ & $\begin{array}{l}\text { Do Not } \\
\text { Unbundle }\end{array}$ \\
\hline $\begin{array}{l}\text { Unbundling is not technically feasible, } \\
\text { UNE is competitively supplied, output is } \\
\text { not competitively supplied }(N, Y, N)\end{array}$ & $\begin{array}{c}\text { Do Not } \\
\text { Unbundle }\end{array}$ & $\begin{array}{c}\text { Do Not } \\
\text { Unbundle }\end{array}$ & $\begin{array}{l}\text { Do Not } \\
\text { Unbundle }\end{array}$ \\
\hline $\begin{array}{l}\text { Unbundling is not technically feasible, } \\
\text { UNE is not competitively supplied, } \\
\text { output is competitively supplied } \\
(\mathrm{N}, \mathrm{N}, \mathrm{Y})\end{array}$ & $\begin{array}{c}\text { Do Not } \\
\text { Unbundle }\end{array}$ & $\begin{array}{l}\text { Do Not } \\
\text { Unbundle }\end{array}$ & $\begin{array}{c}\text { Do Not } \\
\text { Unbundle }\end{array}$ \\
\hline $\begin{array}{l}\text { Unbundling is not technically feasible, } \\
\text { UNE is not competitively supplied, } \\
\text { output is not competitively supplied } \\
(\mathrm{N}, \mathrm{N}, \mathrm{N})\end{array}$ & $\begin{array}{c}\text { Do Not } \\
\text { Unbundle }\end{array}$ & $\begin{array}{c}\text { Do Not } \\
\text { Unbundle }\end{array}$ & $\begin{array}{l}\text { Do Not } \\
\text { Unbundle }\end{array}$ \\
\hline $\begin{array}{l}\text { Unbundling is technically feasible, UNE } \\
\text { is competitively supplied, output is } \\
\text { competitively supplied }(\mathrm{Y}, \mathrm{Y}, \mathrm{Y})\end{array}$ & Enbundle & $\begin{array}{l}\text { Do Not } \\
\text { Unbundle }\end{array}$ & $\begin{array}{c}\text { Do Not } \\
\text { Unbundle }\end{array}$ \\
\hline $\begin{array}{l}\text { Unbundling is technically feasible, UNE } \\
\text { is competitively supplied, output is not } \\
\text { competitively supplied }(\mathrm{Y}, \mathrm{Y}, \mathrm{N})\end{array}$ & Unbundle & $\begin{array}{c}\text { Do Not } \\
\text { Unbundle }\end{array}$ & $\begin{array}{c}\text { Do Not } \\
\text { Unbundle }\end{array}$ \\
\hline $\begin{array}{l}\text { Unbundling is technically feasible, UNE } \\
\text { is not competitively supplied, output is } \\
\text { competitively supplied }(\mathrm{Y}, \mathrm{N}, \mathrm{Y})\end{array}$ & Unbundle & Unbundle & $\begin{array}{c}\text { Do Not } \\
\text { Unbundle }\end{array}$ \\
\hline $\begin{array}{l}\text { Unbundling is technically feasible, UNE } \\
\text { is not competitively supplied, output is } \\
\text { not competitively supplied }(\mathrm{Y}, \mathrm{N}, \mathrm{N})\end{array}$ & Unbundle & Unbundle & Unbundle \\
\hline Unbundling Results & 4 of 8 & 2 of 8 & 1 of 8 \\
\hline
\end{tabular}

Note: We assume that the efficient-competitor standard, like the consumer-welfare standard, incorporates a technical-feasibility requirement. 
As the Table shows, the FCC's original rule of "technically feasible" unbundling would mandate unbundling in half of the possible scenarios. With respect to its outcomes (as opposed to its intellectual grounding), the efficient-competitor standard resembles the FCC's original "technically feasible" unbundling rule more closely than does our proposed consumer-welfare standard.

The preceding comparison of the efficient-competitor standard with our proposed consumer-welfare standard presupposes that it would be feasible for the FCC to define in the abstract, and identify in the concrete, an "efficient" CLEC. There are multiple reasons, however, to expect that such an exercise would be daunting. There is no reason to expect CLECs to be homogeneous firms, such that the FCC could make uniform assumptions about production technologies. CLECs vary in size, lines of business, regulatory burdens or advantages, brand name recognition, and so forth. AT\&T, for example, has cable television and wireless businesses through which it can offer local access for voice telephony, as well as a brand name that is immediately recognizable to consumers. MCI-WorldCom, as of September 1999, had neither cable television nor wireless, and the company presumably still faces challenges in uniting the separate corporate identities of MCI and WorldCom. Meanwhile, Sprint has wireless, no cable television, and extensive operational experience as a traditional ILEC in a number of geographic markets. Which of those three firms would the FCC deem the most "efficient" for purposes of an efficient-competitor standard for $\S 251(d)(2)$ and why? The question becomes even more difficult in light of the fact that MCI-WorldCom announced in October 1999 its intention to acquire Sprint. ${ }^{270}$ Furthermore, how would the FCC evaluate the efficiency of smaller CLECs, such as Winstar or Teligent or RCN, relative to the efficiency of the large IXCs?

The FCC, of course, could undertake engineering-cost modeling of a hypothetically efficient CLEC. But that prospect cannot be regarded as appealing or promising. By comparison, the Commission undertook to model the costs of a hypothetically efficient ILEC in order to generate TELRIC estimates with which to establish proxy rates for UNEs. That exercise generated controversy and litigation. ${ }^{271}$ More fundamentally, as a matter of both jurisdiction and economic policy, the FCC would be treading on shaky ground if, in the name of implementing its policy of mandatory unbundling, it resorted to creating ersatz cost-of-service regulation for unregulated CLECs.

270. See Laura M. Holson \& Seth Schiesel, MCI To Buy Sprint in Swap of Stock for $\$ 108$ Billion, N.Y. TIMES, Oct. 5, 1999, at Al.

271. See Hausman, supra note 168, at 24-26; see also SIDAK \& SPULBER, supra note 4, at 421 (discussing the Hatfield model). 
In short, if the FCC were to interpret $\$ 251(\mathrm{~d})(2)$ under an efficient-competitor standard, it would invariably be compelled to make precisely the kinds of predictions about "best" technologies that Congress resolved, in the Telecommunications Act of 1996, that the market is better suited to supply. The Commission emphasized shortly before its issuance of the Second Further Notice of Proposed Rulemaking that it would not hazard such predictions. ${ }^{272}$ Clearly, such intervention would not "reduce regulation" in the pursuit of "lower prices and higher quality services for American telecommunications consumers." 273

\section{PROCEDURES FOR EFFICIENTLY ADMINISTERING THE IMPAIRMENT TEST}

Economic analysis should guide the Commission in establishing evidentiary rules for mandatory unbundling proceedings and in allocating factfinding responsibilities between the state public utility commissions and the FCC itself.

\section{A. Evidentiary Burdens and Sunset Mechanisms}

Through its design of evidentiary rules, the FCC should create efficient incentives for ILECs and CLECs to discover and reveal information about optimal network design, usage, and investment. Here, the Commission should apply the legal scholarship on economic analysis of evidentiary law.74 Evidentiary presumptions and burdens of proof under $\S 251$ (d)(2) should be assigned to the party (ILEC or CLEC) that is the most efficient producer of the information sought. In most cases, that party will be the CLEC. The rebuttable presumption, therefore, should be that mandatory unbundling of any given network element at a TELRIC price is not required by $\$ 251(\mathrm{~d})(2)$. That allocation of evidentiary burden would be analogous to the plaintiff's burden of proof in an essential-facilities-doctrine case. ${ }^{275}$

272. In early 1999, the FCC stated: "Our role is not to pick winners and losers, or to select the best technology to meet consumer demand. We intend to rely as much as possible on free markets and private enterprise." Inquiry Conceming the Deployment of Advanced Telecommunications Capability to All Americans in a Reasonable and Timely Fashion. 14 F.C.C.R. 2398, 15 (1999).

273. Telecommunications Act of 1996, Pub. L. No. 104104, pmbl.. 110 Stat. 56. 56.

274. See Richard D. Friedman, Economic Analysis of Evidentian Law: An Underused Tool. an Underplowed Field, 19 CARDOZO L. REv. I531, 1533 (1998); Bruce L. Hay, Allocaring the Burden of Proof, 72 IND. L.J. 651 (1997); Jason S. Johnston. Bayesian Fact-Finding and Efficiency: Toward an Economic Theory of Liability Under Uncertainn, 61 S. CAL L. REV. 137 (1987); Richard A. Posner, An Economic Approach to the Law of Evidence. SI STAN. L. REV. 1477 (1999); Richard A. Posner, An Economic Approach to Legal Procedure and Judicial Administration, 2 J. LEGAL STUD. 399, 410 (1973).

275. See Apartment Source, L.P. v. Philadelphia Newspapers, No. 98-5472, 1999 WV 191649 , at *7-*8 (E.D. Pa. Apr. 1, 1999). 
If CLECs are currently the most efficient producers of the information sought regarding the competitive justifications for mandatory unbundling, then it is even more likely CLECs will also be the most efficient producers of information in the future. In the Second Further Notice of Proposed Rulemaking, the Commission sought "comment on an approach that would allow sunset or modification of the unbundling obligations as technology and market conditions evolve over time." ${ }^{276}$ At the end of a finite time horizon, or upon the entry of a facilities-based competitor, the unbundling order should sunset automatically. Specifically, the passage of two years (the time horizon used in the Merger Guidelines), or the entry of a facilities-based competitor of the stature of AT\&T, MCI-WorldCom, or Sprint, should provide the Commission the requisite "passage of time or occurrence of certain events" after which the mandatory unbundling obligations for the ILEC's elements should sunset "without any subsequent action by the Commission." 277 The CLEC should bear the burden of proving that continued mandatory unbundling of the element is indispensable for consumer welfare.

\section{B. The Proper Role of State Commissions in Administering the Proposed Test}

The state public utilities commissions (PUCs) should play an active role in administering the "necessary" and "impair" requirements. The FCC is capable of announcing a general standard for determining whether a network element is subject, under $\S 251$ (d)(2), to mandatory unbundling at TELRIC prices. But the FCC correctly noted in its Second Further Notice of Proposed Rulemaking that "application of the 'necessary' and 'impair' standards that we develop pursuant to $\S 251$ (d)(2) may be relatively fact-intensive." ${ }^{278}$ More important, many of the critical facts are likely to be unique to a particular geographic market and are thus directly "relevant to a decision to impose minimum national unbundling requirements." 279

To apply our five-part test for "impairment," regulators should examine data on the network facilities and equipment that competitors have actually deployed, intend to deploy, or are capable of deploying over the relevant time horizon, to supply service in a relevant product market and geographic market. Regulators should examine as well the implications for

276. Second Further Notice of Proposed Rulemaking, supra note 3, 111 ; see also id. 136 (" [W]hether the Commission should adopt a mechanism by which network elements would no longer have to be unbundled at a future date."); id. ("[W]hether affirmative steps by the parties or the Commission should be necessary to remove a particular element from unbundling requirements, or whether affirmative action should be necessary to continue requiring the unbundling of particular elements.").

277. Id. $\mathbb{\text { II } 3 9 .}$

278. Id. 12.

279. Id. 14. 
facilities-based entry in that geographic market of the substantial acquisitions, by AT\&T and other telecommunications carriers, of the nation's largest competitive access providers, cable television multiple system operators, and wireless carriers. AT\&T's expenditure of (or commitment to spend) more than $\$ 100$ billion on acquisitions of cable television networks, which has all occurred in the three years following the enactment of the Telecommunications Act, calls into question whether it is necessary for competition that AT\&T receive unbundled access at TELRIC prices to ILEC network elements in areas where it now owns cable networks or has joint ventures with other cable network owners. Furthermore, it is extremely unlikely that competition would be impaired in those areas if AT\&T did not have access to unbundled elements at regulated prices, because those cable networks pass over ninety-five percent of households, and AT\&T has announced that the networks will be used to provide telephone and internet services. Thus, application of our impairment test to the areas in which AT\&T has cable networks would likely yield different conclusions from those for areas in which AT\&T does not own cable networks or have joint ventures with other cable partners.

The sheer volume of unbundling proceedings that can be expected, and the numerous questions that those proceedings will necessarily present regarding competitive conditions in particular geographic markets, will severely tax the FCC's resources, in particular because the Commission has properly committed itself to "resolving these fact-intensive questions . . . in an expedited time frame." 280 That administrative burden may prove to be especially great because the FCC acknowledged in late 1998 that "[i]t does not yet possess the detailed information necessary to evaluate the current state of local telephone competition on a market-by-market basis." 281 Because markets create and process vast quantities of information, it is challenging enough for regulators to digest all of the pertinent economic facts concerning competition in a particular service in a particular geographic market. Surely it would overwhelm even the most indefatigable regulatory staff to try to digest, simultaneously and centrally from Washington, the salient facts in all of the relevant product markets and geographic markets for local telecommunications services in the United States. ${ }^{282}$ Yet, the FCC has no alternative to undertaking such geographically specific analysis-unless, of course, the agency's economic analysis of optimal unbundling principles (as opposed to the application of those principles to specific cases in specific geographic markets) would enable the FCC to conclude that a particular network element could not

280. Id. $\Phi 12$.

281. INDUSTRY ANALYSIS DIV., supra note 212, at 3.

282. See generally Friedrich A. Hayek, The Use of Knowledge in Sociery. 35 AN. ECON. REV. 519 (1945). 
satisfy the "necessary" or "impair" requirement in any geographic market in the United States and thus should be removed altogether from the list of potential network elements subject to mandatory unbundling at TELRIC prices. ${ }^{283}$

Fortunately, the state PUCs have the resources and factfinding experience to assist the FCC in conducting the analysis that is essential to administer the "necessary" and "impair" standards with the requisite degree of geographic specificity. Indeed, Congress already recognized that state regulators have a comparative advantage in compiling and analyzing facts about local competition in particular geographic markets. Congress did so through its design of both the local competition provisions ${ }^{284}$ and the interLATA entry provisions ${ }^{285}$ of the Telecommunications Act of 1996. Between the fall of 1996 and the Supreme Court decision in lowa Utilities Board, issued in January 1999, the state PUCs held hundreds of local arbitration proceedings to set the prices for unbundled network elements and the discounts for wholesale services. ${ }^{286}$ Similarly, the checklist process under $\$ 271$ directly involves the state commissions in precisely the kind of geographically specific factfinding that would properly inform the implementation of the "necessary" and "impair" requirements of $\S 251(\mathrm{~d})(2)$.

In short, Congress concluded in 1996 that the states are competent to conduct the fact-intensive arbitration proceedings envisioned in $\$ 252$ and the equally fact-intensive analyses of local telecommunications markets envisioned in the competitive checklist of $\S 271$. It is reasonable to expect that those same state commissioners are competent as well to apply a general rule enunciated by the FCC, pursuant to its Second Further Notice of Proposed Rulemaking, to the specific facts concerning the relevant product markets and geographic markets within those commissioners' respective states. Uniform national outcomes are neither necessary nor conducive to consumer welfare.

It is therefore appropriate to conclude that the "states may, consistent with the Supreme Court's decision, apply [the FCC's] interpretation of $\S 251$ (d)(2) to determine in the first instance that a network element need not be unbundled in light of the availability of that element outside the incumbent's network in that state." ${ }^{287}$ Basic principles of the economics of

283. Cf. Second Further Notice of Proposed Rulemaking, supra note 3, II 36 (discussing "whether the Commission should adopt a mechanism by which network elements would no longer have to be unbundled at a future date").

284. See 47 U.S.C.A. $\$ 252$ (b) (West Supp. 1999).

285. See id. $\$ 271(\mathrm{c})(1)(\mathrm{A})$ (describing the requirements for state approval of the RBOC's generic interconnection plan); id. $\$ 271(\mathrm{c})(1)(B)$ (setting forth alternative procedures if no requests for interconnection are forthcoming); id. \$272(b) (providing a competitive checklist).

286. See Sidak \& Spulber, supra note 4, at 1082-83.

287. Second Further Notice of Proposed Rulemaking, supra note 3.914. 
information support the conclusion that Congress intended, through its enactment of the Telecommunications Act, for the states to play an active role in determining whether a particular network element in a specific geographic market is subject to mandatory unbundling at arbitrated (which is to say, regulated) prices. If, as seems most reasonable to infer, Congress already gave the states that authority, then it would be unnecessary for the FCC to adopt rules purporting "to delegate to the states responsibility for removing network elements from any national unbundling requirements" that the FCC promulgated. ${ }^{288}$ Economic reasoning counsels that Congress already commended that power to the states, such that the Commission in fact has no "opt out" authority to delegate to them. Like the unbundling rules themselves, the extent of the states' participation in the implementation of $\S 251$ (d)(2) should not be regarded by the FCC as being conditional on its exercise of "regulatory grace." "259

As we discussed above, separate local telecommunications markets exist with different degrees of competition throughout the United States. For the FCC to attempt to establish rules for each of those local telecommunications markets would be extremely time consuming if the proper fact-intensive investigation were performed for each telecommunications market. If the FCC instead were to take a broad-brush approach without considering and analyzing the market-specific factors, the agency would likely err in many of its decisions. In turn, those errors would reduce both innovation in and the quality of telecommunications services available to consumers, a result that would frustrate the objectives of the Telecommunications Act.

\section{CONCLUSION}

Even after the Supreme Court's remand in lowa Utilities Board, the FCC continues to interpret its authority to mandate the unbundling of the local telecommunications network at regulated, cost-of-service prices in a manner that is at war with the antitrust laws. The agency's interpretation of "necessary" and "impair" for the purpose of $\$ 251$ (d)(2) cannot find support in sound economic analysis, because no responsible economist could defend subordinating the welfare of consumers to the welfare of individual competitors. The proper interpretation of $\S 251$ (d)(2) would give primacy to consumer welfare and would use the competitive analysis of demand substitutability and supply substitutability, as the long-established tools of economic analysis of competition and of antitrust jurisprudence, to ensure, as Congress directed, that the unbundling rules successfully "promote

289. AT\&T v. Iowa Utils. Bd., I 19 S. Ct. 721. 736 (1999). 
competition and reduce regulation in order to secure lower prices and higher quality services for American telecommunications consumers and encourage the rapid deployment of new telecommunications technologies." 290

Our impairment test asks whether the ILEC could exercise market power in the end-user services market by restricting access to a particular network element. Regulators attempting to employ our standard, however, may require simple, objective market characteristics that would serve as proxies for constraints on an ILEC's ability to exercise market power in the end-user services market. In particular, three market characteristics should be incorporated into the decisionmaking process:

(1) Whether a CLEC is self-supplying the element in question in the relevant geographic market. As long as one CLEC is supplying the element in question, the ILEC cannot exercise market power in the end-user services market by restricting access to that element.

(2) Whether fixed (as opposed to sunk) costs represent a large share of the total costs of the element in question. As long as the asset is redeployable, the CLEC will not face barriers to exit, which in turn, implies low entry barriers. Thus the ILEC cannot exercise market power in the end-user services market by restricting access to that element.

(3) Whether AT\&T or any other firm offering cable telephony has established a presence in the relevant geographic market. As long as one firm is offering cable telephony service, the ILEC cannot exercise market power in the end-user services market by restricting access to that element.

The first two conditions represent supply-side substitution constraints, while the third condition is a demand-side substitution constraint on the exercise of market power in the end-user services market.

With respect to the Telecommunications Act's goal of "promoting competition," our analysis and proposed test of "impairment" are rooted in economic analysis of competition and antitrust law, which are designed to promote consumer welfare. Our proposed test for "impairment" would follow Congress's directive to "reduce regulation." 291 In contrast, the competitor-welfare approach of the Second Further Notice of Proposed Rulemaking and the Local Competition First Report and Order would expand regulation because any CLEC could trigger regulatory intervention by asserting that its profitability would be diminished by the inability to lease the ILEC's unbundled elements at TELRIC prices. Our approach requires that the CLEC's request for a particular unbundled network 
element satisfy the four existing requirements of the essential facilities doctrine and then also meet a fifth requirement, based on critical share, that examines whether an attempt by the ILEC to deny the CLEC access to the element in question would decrease competition in the output market for telecommunications services. In so doing, our impairment test advances consumer welfare and provides the "limiting principle" that the Supreme Court demanded in lowa Utilities Board. 
